\title{
Cancer and reconstructive surgery in inflammatory bowel disease
}

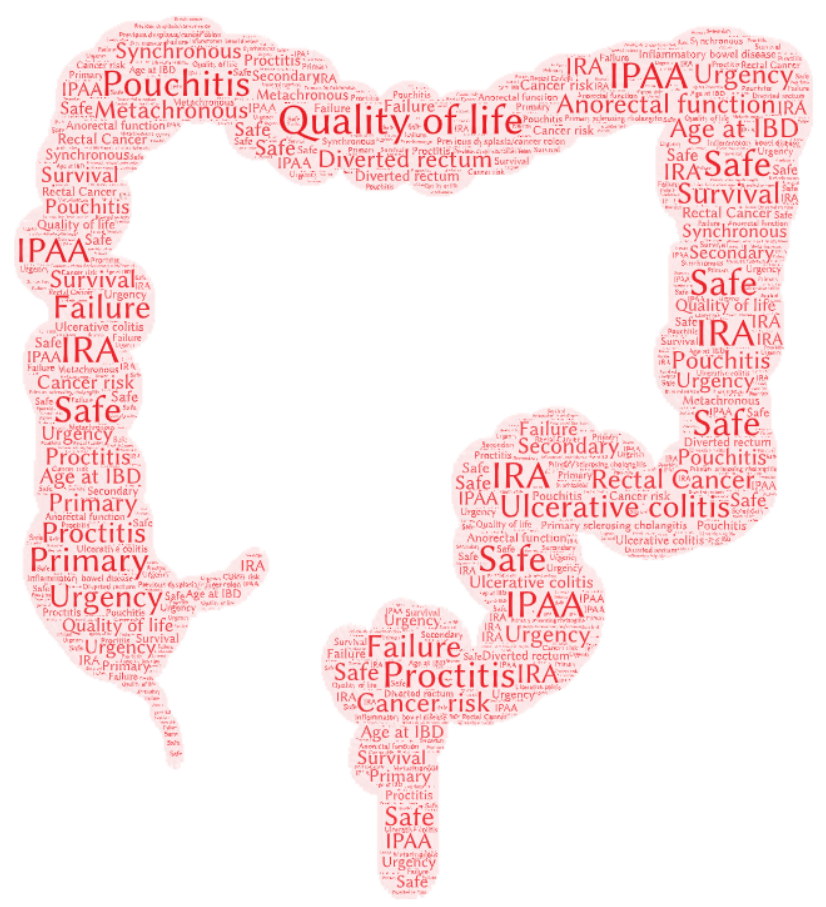

Maie Abdalla 
Linköping University, Medical Dissertation, No. 1670

\title{
Cancer and reconstructive surgery in Inflammatory bowel disease
}

\author{
Maie Abdalla
}

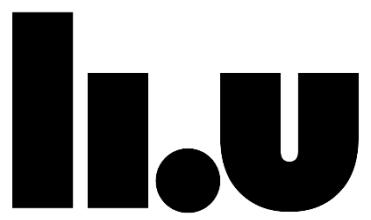

LINKÖPINGS UNIVERSITET

Linköping 2019

Division of Surgery,

Department of clinical and experimental medicine,

Faculty of Medicine and Health Sciences,

Linköping, Sweden 
(C) Maie Abdalla 2019

The published articles have been reprinted with permission of the copyright holder

Printed in Sweden by LiU-Tryck, Linköping, Sweden

ISBN: 978-91-7685-109-8

ISSN: 0345-0082 


\section{بسم الله الرحمن الرحيم}

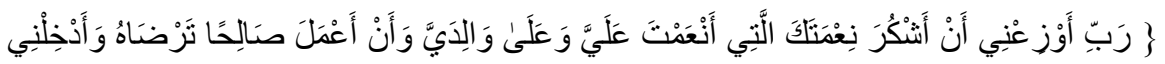

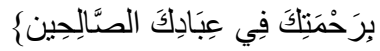

صدق الله العظيم

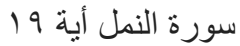

\section{In the name of God, the merciful}

( My Lord enable me to be grateful for your favour which you have bestowed upon me and upon my parents and to do righteousness of which you approve, and admit me by your mercy into the ranks of your righteous servants)

The Holly Quran

Surat Al-naml: Aya 19 


\section{Principle Supervisor}

Pär Myrelid, Associate professor

Division of surgery, Department of clinical and experimental medicine, Faculty of Medicine and Health sciences, Linköping University, Linköping, Sweden

\section{Assistant supervisors}

Johan D Söderholm, Professor

Division of surgery, Department of clinical and experimental medicine, Faculty of Medicine and Health sciences,

Linköping University, Linköping, Sweden

Roland E Andersson, Professor

Division of surgery, Department of clinical and experimental medicine, Faculty of Medicine and Health sciences, Linköping University, Linköping, Sweden

Department of surgery, Ryhov County Hospital, Jönköping, Sweden

Kalle Landerholm, Ph.D.

Division of surgery, Department of clinical and experimental medicine, Faculty of Medicine and Health sciences, Linköping University, Linköping, Sweden Department of surgery, Ryhov County Hospital, Jönköping, Sweden 


\section{Opponent}

Yves Panis, Professor

Division of surgery,

Beaujon hospital, University hospitals of Paris the North valley of the Seine

Clichy, France

\section{Committee board}

Urban Karlbom, Associate professor

Division of surgery,

Akademiska Sjukhuset,

Uppsala, Sweden

Christopher Sjöwall, Assistant professor,

Division of Neuro and inflammation/ Rheumatology,

Department of clinical and experimental Medicine,

Faculty of Medicine and Health sciences,

Linköping University, Linköping, Sweden

\section{Substitute}

Stergios Keshagias, Professor

Division of Cardiovascular Medicine (KVM),

Department of Medical and Health Sciences (IMH),

Faculty of Medicine and Health sciences,

Linköping University, Linköping, Sweden 


\section{List of Contents}

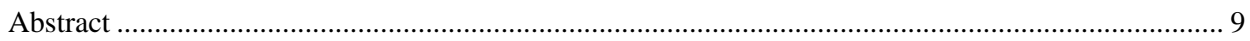

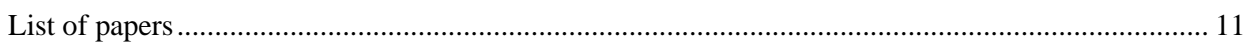

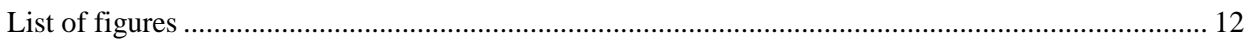

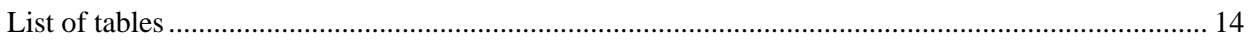

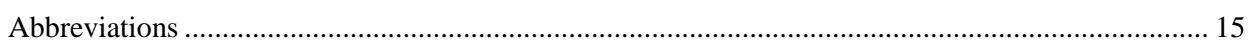

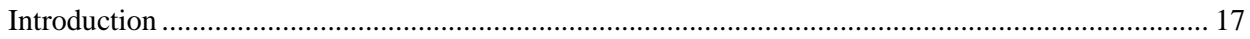

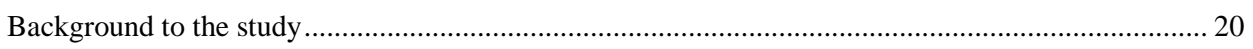

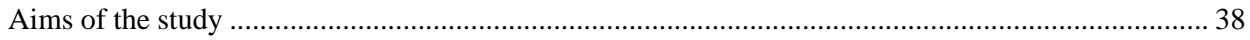

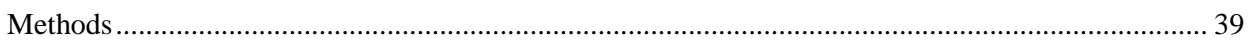

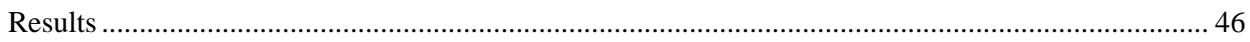

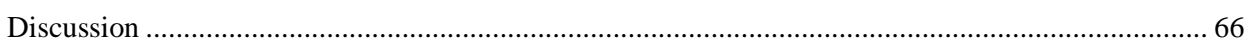

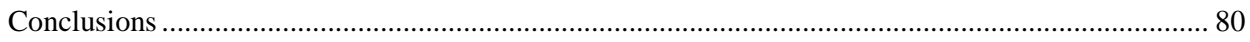

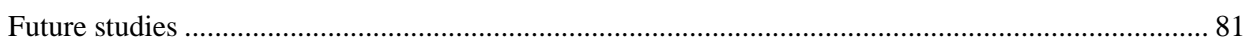

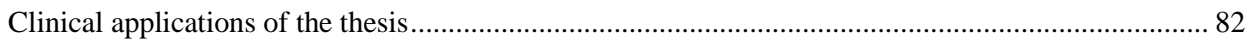

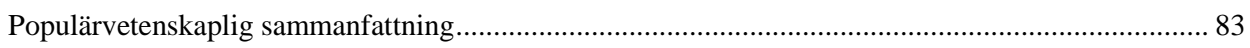

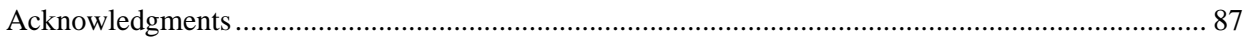

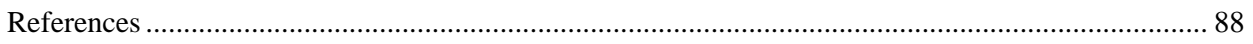

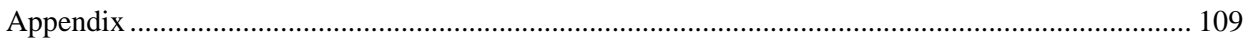

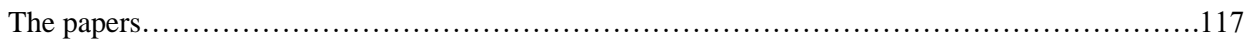




\begin{abstract}
Ulcerative colitis (UC) is a chronic inflammatory disease that affects the colon. According to the literature, some thirty percent of UC patients may require a subtotal colectomy and ileostomy due to failure of medical treatment, acute toxic colitis or dysplasia/cancer diagnosis. Some patients choose to get continence restored with either an ileorectal anastomosis (IRA) or an ileal pouch-anal anastomosis (IPAA). Worldwide most surgeons prefer an IPAA to an IRA, despite reports of pouchitis, impaired fertility and fecundity. Fear of recurring proctitis and fear of rectal cancer in the remaining rectum is contributing to the choice of an IPAA. Little is known regarding the outcomes of IRA compared with IPAA in UC patients. We aimed to investigate the anorectal function, quality of life (QoL), risk of failure and rectal cancer in patients with UC restored with IRA and IPAA respectively.
\end{abstract}

Methods: Data about all Inflammatory bowel disease (IBD) patients was obtained from the Swedish National Patient Register (NPR) between 1964-2014 and in one study from the Linköping University Hospital medical records 2006-2012. Patients who developed cancer were identified from the Swedish National Cancer Register. We investigated the risk of cancer and inflammation, functional outcome and failure as well as the quality of life for IRA and IPAA patients. Investigation of risk for cancer in IRA and IPAA compared with the background population was performed using survival analytic techniques: uni-and multivariate regression, Kaplan Meier curves and standardized incidence ratio.

Results: Twelve percent $(7,889 / 63,795)$ of UC patients required colectomy according to the NPR. The relative risk for rectal cancer among patients with an IRA was increased (SIR 8.7). However, the absolute risk was $1.8 \%$ after a mean follow up of 8.6 years and the cumulative risk 10- and 20-years after IRA was $1.6 \%$ and 5.6\%, respectively. Risk factors for rectal cancer were primary sclerosing cholangitis in patients with an IRA (hazard ratio 6.12), and 
severe dysplasia or cancer of the colon prior to subtotal colectomy in patients with a diverted rectum in place (hazard ratio 3.67). Regarding IPAA, the relative risk to develop rectal cancer was (SIR 0.4) compared with the background population and the absolute risk was only $0.06 \%$ after a mean of 12.2 years of follow up.

Among patients operated at the Linköping University Hospital: IRA patients reported better overall continence according to the Öresland score with in median3 (IQR 2-5) for IRA ( $\mathrm{n}=38$ ) and 10 (IQR 5-15) for IPAA $(\mathrm{n}=39, \mathrm{p}<0.001)$. There were no major differences regarding the QoL.

According to the NPR, after a median follow up of 12.4 years failure occurred in $265(32 \%)$ out of 1112 patients, of which 76 were secondarily reconstructed with an IPAA. Failure of the IPAA occurred in $103(6 \%)$ patients with primary and in $6(8 \%)$ patients after secondary IPAA (log-rank $p=0.38)$.

Conclusion: IRA is a safe restorative procedure for selected UC patients. Patients should be aware of the annual postoperative endoscopic evaluation with biopsies as well as the need to the use of local anti-inflammatory preparations.

However, IRA should not be offered for UC patients with an associated primary sclerosing cholangitis diagnosis due to the increased risk to develop rectal cancer in their rectal mucosa. In such case, IPAA is probably the treatment of choice. 


\section{List of papers}

Paper I: The risk of rectal cancer after colectomy for patients with ulcerative colitis: A national cohort study.

Paper II: Survival of ileal pouch anal anastomosis constructed after colectomy or secondary after an ileorectal anastomosis in ulcerative colitis patients: a population-based cohort.

Paper III: Quality of life in ulcerative colitis patients restored with pelvic pouch or ileo-rectal anastomosis after colectomy.

Paper IV: Impact of inflammatory bowel disease and primary sclerosing cholangitis on risk and location of colorectal cancer. A national cohort study. 


\section{List of figures}

Figure 1: Grades of inflammation detected in Ulcerative colitis via endoscopy

Figure 2: Microscopic picture of ulcerative colitis

Figure 3: Endoscopic and histologic picture of Crohn's colitis

Figure 4: Endoscopic and microscopic pictures of a colonic adenocarcinomas.

Figure 5: MRCP of the biliary tree showing dilated biliary ducts typical for PSC

Figure 6: Ilea-rectal anastomosis (IRA). 30

Figure 7: A simplified drawing of the Kock pouch...

Figure 8: Ileal-pouch anal anastomosis (IPAA).

Figure 9 :The studied populations in the thesis.

Figure 10: Kaplan Meier curve investigating the effect of possible risk factors on the rectal cancer free survival 48

Figure 11: Kaplan Meier curve analysing the effect of possible risk factors on the rectal cancer free survival of ulcerative colitis patients with an intact and diverted rectum. 50

Figure 12: The risk of IPAA failure was similar after primary and secondary reconstruction 52

Figure 13: Flow chart of the included study participants in Paper III. 53

Figure 14: Boxplots of the medians and CI 95\% of Öresland score in UC patients operated with IRA and IPAA.

Figure 15: Boxplots of the medians and 95\% confidence interval of SF-36 in ulcerative colitis patients operated with IRA or IPAA. 56

Figure 16: Flow chart of the studied population in paper IV. 59

Figure 17: Cumulative risk of developing CRC in patients with inflammatory bowel disease. with and without primary sclerosing cholangitis as well as matched controls according to age of IBD diagnosis and length of follow up. 62 
Figure 18: Hazard ratio and (95\% CI) of cancer distribution in inflammatory bowel disease patients with and without primary sclerosing cholangitis compared to controls from the Swedish population. 63 


\section{List of tables}

Table 1 Demographics of the studied population (paper I) of 5,886 patients with ulcerative colitis that were operated with subtotal colectomy during 1964-2010

Table 2: The demographics of the studied population paper II

Table 3: Results of pathology reports: histological grades of inflammation, types and site of dysplasia and number of polyps.

Table 4: Incidence rate ratio of age groups to develop colo-rectal cancer for inflammatory bowel disease patients with and without a concomitant diagnosis of primary sclerosing cholangitis, all compared with controls without an IBD diagnosis.

Table 5: Type of resection in IBD patients diagnosed with metachronous cancers classified by subdiagnoses.

Supplementary table 1: ICD codes for the studied populations in the thesis.

Supplementary table 2: the Nordic Medico-Statistical Committee (NOMESCO) codes for operations included in the thesis.

Supplementary table 3: Öresland score

Supplementary table 4: Short form-36 (SF-36)

Supplementary table 5: Short health scale (SHS)

Supplementary table 6: Baron-Ginsberg score (BG score) 116 


\title{
Abbreviations
}

\author{
UC Ulcerative Colitis \\ IBD Inflammatory Bowel Disease \\ IRA Ileo-rectal Anastomosis \\ IPAA Ileal Pouch Anal Anastomosis \\ DR Diverted Rectum \\ PSC Primary Sclerosing Cholangitis \\ RC Rectal Cancer \\ SC Subtotal Colectomy \\ SIR Standardized Incidence Ratio \\ SCR Swedish Cancer Register \\ ICD International Classification of Diseases \\ NOMESCO Nordic Medico-Statistical Committee \\ IQR Inter-quartile range \\ QOL Quality of Life \\ SF-36 Short Form 36 questions \\ SHS Short Health Scale
}

CCGQOL Cleveland Clinic Global quality of life score 
VAS Visual analogue scale

BG score Baron-Ginsberg Score 


\section{Introduction}

Ulcerative colitis (UC) and Crohn's disease (CD) are usually referred to as inflammatory bowel disease (IBD). UC is a colonic disease spreading in a distal to proximal location while CD may involve all parts of the gastrointestinal tract. Ileorectal anastomosis (IRA) was long considered an inappropriate option for reconstruction of patients with UC after colectomy ${ }^{(1)}$ while it often has been considered appropriate among patients with colitis due to Crohn's disease (CD). ${ }^{(2)}$ Despite the advantages of IRA in form of short operative time, less intraoperative bleeding and less postoperative fertility problems, many surgeons hesitate to offer IRA for their patients as an alternative reconstruction after colectomy. ${ }^{(3,4)}$ The reasons behind their hesitation can be summarized into three factors:

a. The remaining rectal mucosa in IRA is exposed to the same underlying pathology that caused UC in the first place which leads to proctitis. In some instances, symptoms of proctitis can be controlled by anti-inflammatory treatment. ${ }^{(5)}$ If treatment fails, patients will suffer from poor reservoir function, mainly in form of urgency and incontinence. ${ }^{(6,7)}$ Subsequently, UC patients operated with an IRA will report a poor QoL.

b. Moreover, there are reports of an $18 \%$ increased risk to develop colorectal cancer (CRC) within 30 years from the UC diagnosis itself. ${ }^{(8)}$ Therefore, one of each five patients who chose an IRA as reconstruction would develop a rectal cancer.

c. IRA would fail in any of the above situations. Then patients are offered a completion proctectomy and either a permanent ileostomy or a secondary reconstruction in form of an ileal pouch anal anastomosis (IPAA) or a Kock pouch. However, success of the secondary reconstruction is not guaranteed. 
All above mentioned factors reasonably contribute not to choose an IRA reconstruction for UC patients.

Additionally, there is also a subpopulation of IBD patients with special characteristics: the primary sclerosing cholangitis (PSC) patients. ${ }^{(9)}$ These patients are known to, in some ways, have a more aggressive disease outcome than the IBD patients without an associated PSC diagnosis. ${ }^{(10,11)}$ It is also known that they develop colorectal cancer (CRC) and cholangiocarcinoma more frequently than IBD patients without a PSC. ${ }^{(12,13)}$ However, little is known about the most common anatomic location of the primary CRC in this subpopulation compared to the total IBD population. The type of colectomy will be customized according to the tumor location and stage, even though restorative proctocolectomy and IPAA is preferred in $\mathrm{UC} .^{(14)}$

It is difficult to find a proper surgical option after colectomy for PSC-IBD patients. PSC patients may develop portal hypertension which causes open porto-systemic shunts, also called bowel wall varicosities. ${ }^{(15)}$ Therefore, many surgeons avoid bowel diversion in form of ileostomy or a Kock pouch. Accordingly, patients are left with one of two reconstruction options, IRA or IPAA. ${ }^{(16),(17)}$ The choice between both types of reconstruction are not properly studied in the case of PSC in UC patients. Previous reports detected an increased risk of pouchitis in UC patients with a concomitant PSC (UC/PSC+) diagnosis when compared to those without PSC (UC/PSC-). However, UC/PSC+ patients did not manifest worse surgical complications after reconstruction with an IPAA than UC/PSC- patients. Subsequently, UC/PSC+ patients did not risk more or earlier failure of their pouches. ${ }^{(18,19)}$ In case of IRA, failure was more frequently reported in UC/PSC+ compared to UC/PSC- patients. ${ }^{(20)}$ Further, we could not find any study commenting on the risk of rectal cancer after colectomy in PSC patients with IRA or IPAA. 
We designed this thesis to critically appraise the claimed disadvantages of IRA as a reconstruction compared to IPAA for UC patients. Moreover, we wanted to evaluate the magnitude of surgical problems that a concomitant PSC diagnosis carries for IBD patients in general and UC patients particularly. Our hypothesis is that IRA may be a good surgical alternative in properly selected UC patients. In such instances, an extra step will be safely added to the stairway of surgical treatment in UC patients and thus helping patients maintain continence for more years after colectomy. 


\section{Background to the study}

\section{Inflammatory bowel disease}

Inflammatory bowel disease (IBD) includes a group of chronic inflammatory disorders that affects mainly the gastro-intestinal tract leading to mucosal inflammation, injury and damage. There are two major IBD categories, ulcerative colitis (UC) and Crohn's disease (CD).

UC is one of the major subtypes of IBD. A recent study on the prevalence of UC reported the highest prevalence in the world to be in Europe with 505/100,000 in Norway compared to 286/100,000 and 319/100,000 in USA and Canada respectively. ${ }^{(21)}$ Several factors are involved in the pathogenesis of UC, including genetic, immunological, familial and environmental factors. ${ }^{(22,23)}$

UC affects the colonic mucosa, usually the inflammation starts in the rectal mucosa and then extends to affect the mucosa in proximal segments of the colon. In 10-20\% of UC patients, the inflammation spreads beyond the ileocecal valve due to valve incompetence causing backwash ileitis, in which up to $30 \mathrm{~cm}$ of the terminal ileum may be inflamed. ${ }^{(24,25)}$

UC patients complain of insidious onset abdominal pain and cramps, diarrhea, rectal bleeding, tenesmus, mucous and in severe cases purulent discharge from the rectum. UC disease course is variable with few or frequent flares interrupted with variable periods of clinical remission. ${ }^{(26)}$

Endoscopic examination of UC patients shows inflamed, hyperemic mucosa that bleeds easily, mucosal ulcerations and in some instances, mucus or purulent discharge. The inflammation has a continuous appearance. Histological examination shows an inflammation confined to the mucosa, mainly in the intestinal crypts. Crypt abscess stimulates the goblet 
cells to increase their mucus discharge. Superficial ulceration occurs with consequent healing with fibrosis causing inflammatory polyps. Serosal inflammation is rare and detected only in patients presented with toxic megacolon. Intestinal dysplasia is an important feature that may present on pathology reports.

UC patients may present with some extra-intestinal manifestations such as uveitis, arthritis, arthralgia, primary sclerosing cholangitis, erythema nodosum and pyoderma gangrenosum. ${ }^{(27)}$ (28)

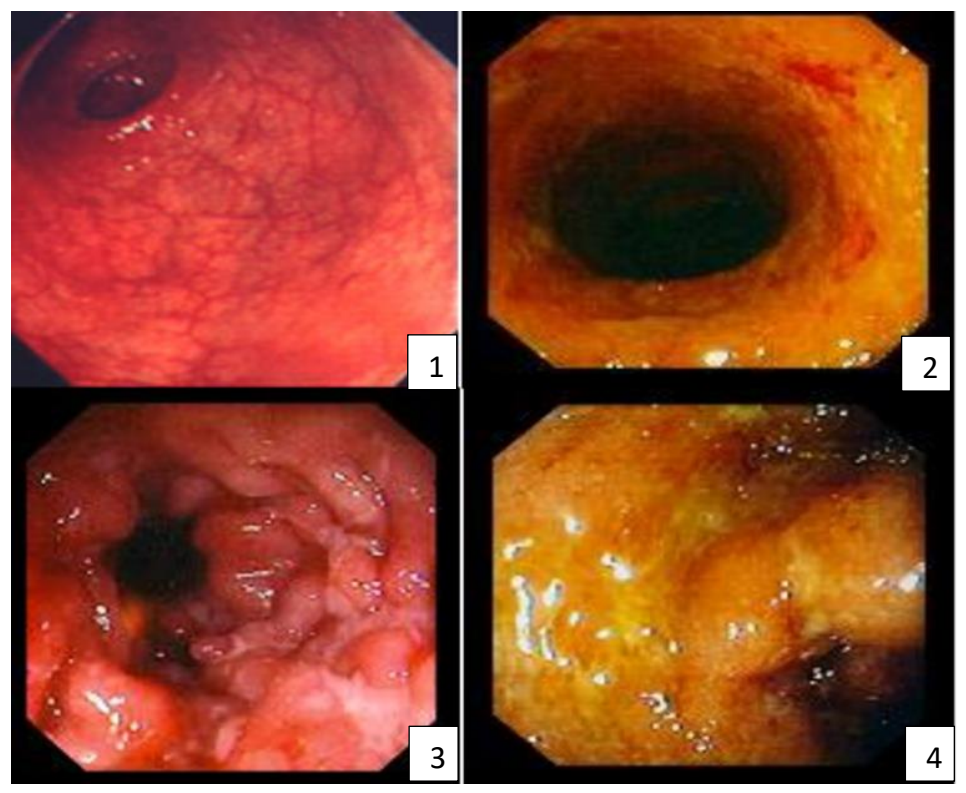

Figure 1: Grades of inflammation detected in Ulcerative colitis via endoscopy.

Photo taken by Pär Myrelid. 1 mild inflammation of mucosa (hyperaemia). 2 moderate inflammation 3 severe inflammation with a visible ulcer. 4 severe inflammation with exudate. 


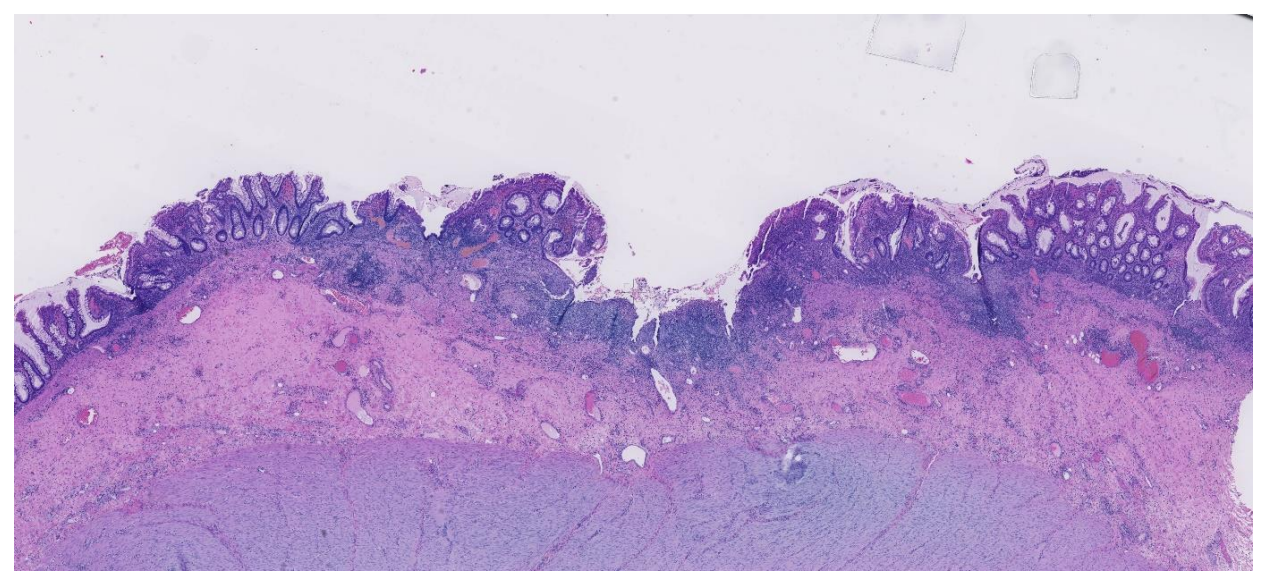

Figure 2: Microscopic picture of ulcerative colitis. Photo taken by Marina Perdiki Grigoriadi

$\mathrm{CD}$ is the other major IBD subtype affecting any part of the gastrointestinal tract from the mouth to the anus. CD is characterized by transmural inflammation of the bowel wall, and often discontinuous areas with inflammation" skip lesions" separated by segments of normal bowel and commonly associated with extra-intestinal manifestations as well.

CD patients commonly complain of intermittent abdominal pain and diarrhea, fatigue. In addition, some patients complain of rectal bleeding, low-grade fever and weight loss. The disease causes malnutrition and thus lead to bone loss and vitamin deficiencies. ${ }^{(29,30)(31)} \mathrm{CD}$ patients also have a variable disease course with flares and periods of remission. ${ }^{(32)}$ The transmural inflammation can complicate the disease, causing obstruction due to intestinal fibrosis and/or fistulation.

Endoscopic examination of CD patients reveals areas of inflamed mucosa with superficial ulcerations over the granulomas, which spread in serpiginous pattern causing the characteristic" cobble-stone" appearance. The inflamed mucosa is interrupted with areas of 
normal appearing mucosa causing the characteristic finding of skip lesions. Both granulomas and skip lesions are characteristic of CD.

Histological examination may show inflammatory infiltration in and around the crypts causing crypt abscesses and superficial mucosal ulcerations. Acute and chronic inflammatory infiltrates form non-caseating granulomas that extends in the submucosa, up to the mesentery and lymph nodes, which may cause inflammatory strictures. Serositis is also common, leading to formation of fibrotic strictures as well as bowel adhesions. Thus, it is common for CD patients to present with an intestinal obstruction. Crypt destruction commonly occur leading to the pipe-like appearance of the bowel. ${ }^{(33)}$

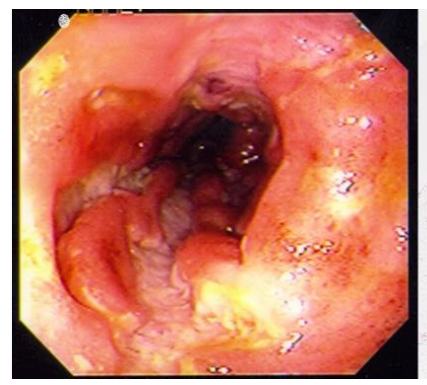

Figure 3: Endoscopic and histologic picture of Crohn's colitis. Photo taken by Pär Myrelid (right) and Marina Perdiki Grigoriadi (left)

There is a third sub-diagnosis among IBD patients: indeterminate colitis (IC). According to the Montreal classification, IC diagnosis is reserved only for patients having had a colectomy and where pathologists still are unable to make a definitive diagnosis of either UC or CD. Moreover, they have suggested a new term "inflammatory bowel disease, type unclassified" (IBD-U). This term entitles to IBD patients, who have colon still in place, with a clinical and 
endoscopic chronic inflammation affecting the colon, without small bowel involvement, and without a definitive histological/ clinical evidence in favor of UC or CD. ${ }^{(34)}$ Little is known about the pathogenesis and clinical course of IBD-U, but it may not be correct to force this group of patients under either a UC or a CD diagnosis. Approximately 10-11\% of adult and $12-18 \%$ of paediatric IBD patients will remain as IBD-U. ${ }^{(35)}$ Another study reported that paediatric IBD-U patients have molecular and serological characteristics more similar to UC than CD. However, $60 \%$ of paediatric IBD-U patients will keep the same diagnosis of an IBD-U even after two years of follow up. ${ }^{(36)}$ It is possible that IBD-U is a true separate IBD sub-diagnosis or that some UC and CD patients are misdiagnosed. Unfortunately, most of previous cohort studies have excluded IBD-U patients from their analyses. Further research is required to better understand the behaviour of an IBD-U.

It is also known that IBD patients are more susceptible to develop colorectal cancer (CRC) compared with the general population. Previous studies have also established that long duration, severe and/or wide-spread colonic inflammation in IBD patients increase the risk to develop CRC. ${ }^{(37)(38)}$ Several genetic and environmental factors contribute to the development of CRC such as genetic instability, epigenetic alteration, oxidative stress that attacks cell and nuclear proteins, immune response caused by mucosal inflammatory mediators, as well as alteration of the intestinal microbiota species, concentration and distribution in the colon. ${ }^{39-}$ 42) (43)

The introduction of novel biological therapy and cancer screening programs with colonoscopy and biopsies offered to IBD patients have raised hope of decreased risk to develop CRC. ${ }^{(44)}$ However, recent reports about the incidence of CRC in IBD patients are conflicting. One recent Danish population-based study concluded that the CRC risk is decreasing in patients diagnosed with UC. ${ }^{(45)}$ On the contrary, another study from the US states that the incidence of $\mathrm{CRC}$ in $\mathrm{UC}$ and $\mathrm{CD}$ patients is $60 \%$ higher when compared with the general population. 
Additionally, they stated that this increased risk was stable over the 20 years duration of the study. ${ }^{(46)}$ We believe that more large-scale cohorts from publicly funded health care systems, that offers biological interventions as well as surveillance to IBD patients, are required to determine the actual risk of CRC.
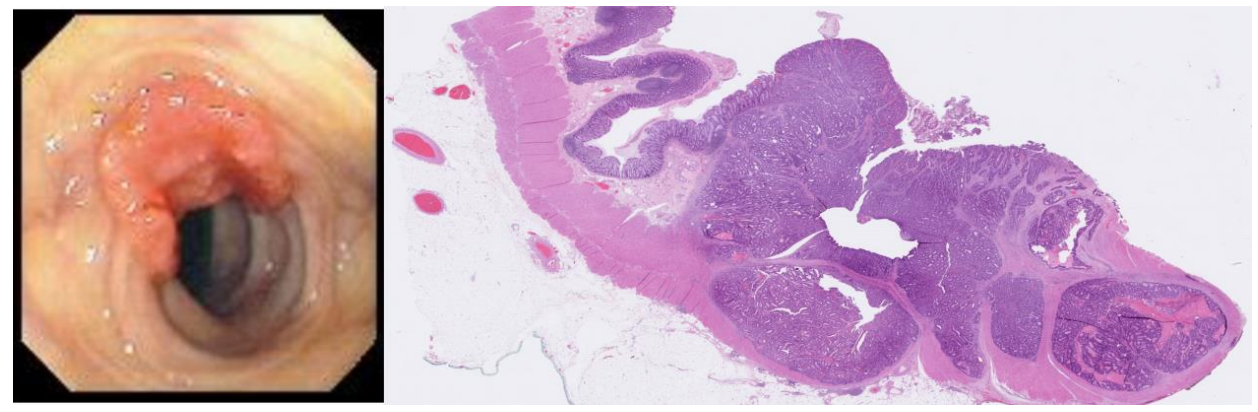

Figure 4: Endoscopic and microscopic pictures of a colonic adenocarcinomas. Photo taken by Pär Myrelid (right) and Marina Perdiki Grigoriadi (left).

IBD patients are more vulnerable to develop synchronous and/or metachronous CRC. ${ }^{(47)}$ This could be due to genetic predisposition ${ }^{(48)}$, persistence of the inflammatory process ${ }^{(49)}$ or missed diagnosis of cancer in case of synchronous cancer. Cancer growth in IBD patients presents as a locally raised mucosa that could be missed in the presence of ulcerative disease, inflamed mucosa, inflammatory polyps and bleeding. Thorough endoscopic surveillance is thus crucial for young IBD patients, because they have a high risk to develop a post colonoscopy colorectal cancer. ${ }^{(50)}$ Studies are required to evaluate the actual risk of synchronous and metachronous cancers in IBD patients to be able to tailor the management plans accordingly. 


\section{Primary sclerosing cholangitis}

PSC is a chronic liver disease characterized by a progressive course of cholestasis with inflammation and fibrosis of the intrahepatic and extrahepatic bile ducts. ${ }^{(51)}$ The progressive fibrosis of biliary ducts leads to liver cirrhosis and portal hypertension and is one of the most common causes of liver transplantation. ${ }^{(52)}$ Between $80-90 \%$ of PSC patients have a diagnosis of IBD as well ${ }^{(53)}$ but usually have an insidious onset of their bowel inflammation and may be asymptomatic or present with mild symptoms, which may delay their diagnosis of IBD. ${ }^{(9)}(54-59)$ The problem is that IBD patients with a PSC diagnosis not uncommonly develop cholangiocarcinoma and/or CRC. ${ }^{(9,60,61)}$ One proposed contributing factor that increases the risk of cancer is that cholestasis causes an accumulation of secondary bile acids, both in the liver and the colon, which is proven to have a carcinogenic effect in animal models. ${ }^{(53,62)}$ Another proposed contributing factor is that IBD/PSC+ patients have a prolonged course of unmanifested subclinical inflammation of the colon that causes no or very mild symptoms. Consequently, it takes time for patients to get diagnosed and properly treated and previous studies detected that a long duration of colonic inflammation increases the risk to develop CRC in UC. ${ }^{(37)(38)}$ 


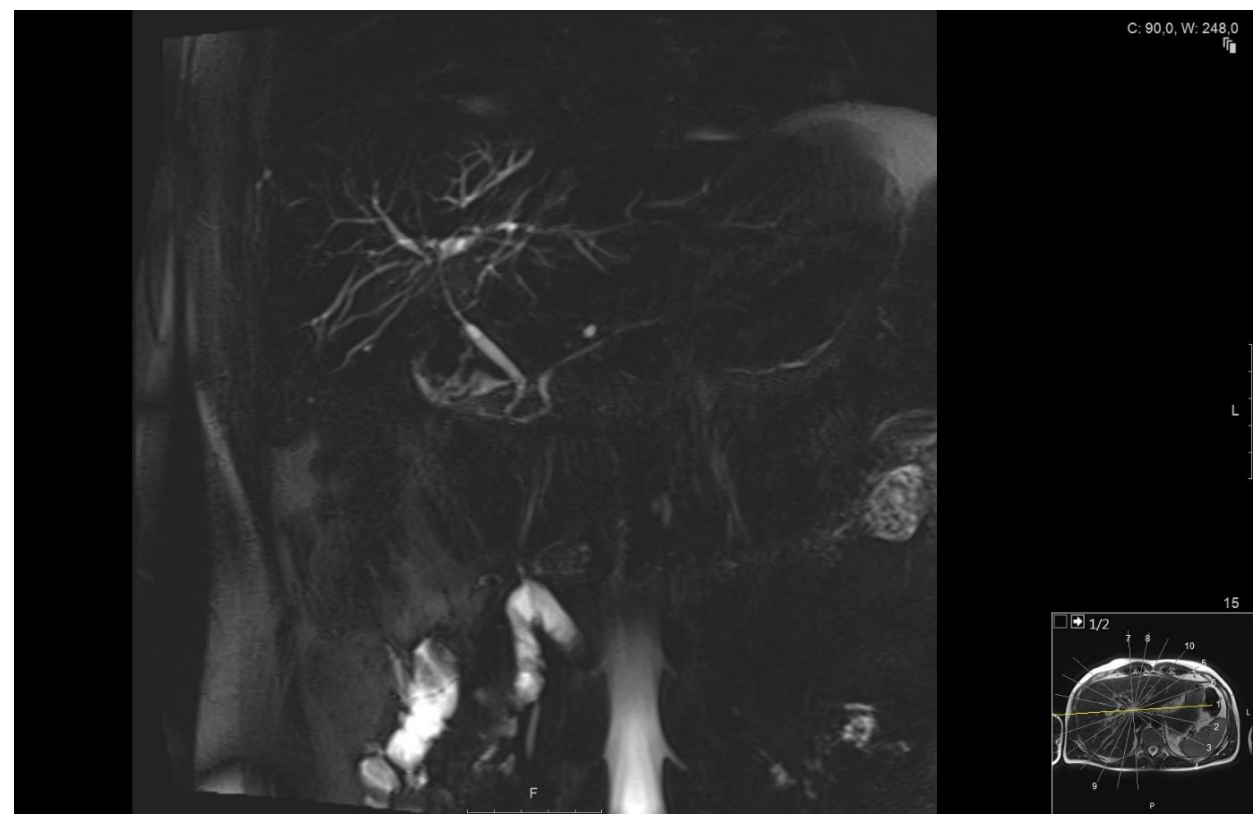

Figure 5: MRCP of the biliary tree showing dilated biliary ducts typical for PSC. Photo taken by Jenny Öman

It is also essential to identify the most common location for CRC in IBD/PSC+ patients to determine the required extent of resection. A recent study reported that CRC are commonly located in the right side of the colon in IBD patients with a concomitant PSC. ${ }^{(63)}$ Another study reported that UC/PSC+ patients who underwent a subtotal colectomy with an ileostomy and a disconnected rectal remnant in situ did not risk to develop neoplasia in their remaining rectal stump.${ }^{(64)}$ Thus it seems that the existence of the enterohepatic circulation and/or preserved faecal stream to the colon or rectum are crucial for the cancer process to occur in IBD/PSC patients. In order to confirm such theory, we need to assess the CRC location for a large sample of IBD patients with PSC.

Theoretically, if PSC increases the risk for primary CRC, it should also increase the risk of synchronous and metachronous cancers. Unfortunately, most studies for CRC in IBD patients 
excluded synchronous and metachronous cancer patients. Studies with focus on the risk for synchronous cancers and metachronous cancer after management of the primary cancer for IBD-PSC patients are required. First to evaluate the effectiveness of the current surgical resections for PSC patients diagnosed with primary CRC in preventing future cancers. Secondly to adjust the overall management plans for PSC-IBD patients before they get their CRC diagnosis.

\section{Surgical reconstruction for ulcerative colitis}

Approximately one-third of patients diagnosed with ulcerative colitis involving the colon proximal to the splenic flexure will require surgery within 15 years of diagnosis in the form of subtotal colectomy and ileostomy ${ }^{(65)}$, either due to a severe flare, medically refractory chronic disease or due to development of dysplasia or invasive cancer. The choice of definitive surgery is made after patients' counseling with surgeon, which depends on patients' age, general condition, persistence of rectal inflammation as well as the results of the pathology report.

Severely ill and malnourished patients are preferred to keep their ileostomy functioning with a diverted rectum (DR) left in place or with a later completion proctectomy. ${ }^{(10)}$ If high grade dysplasia or cancer of the resected colon were detected on the pathology report, completion proctectomy should be performed as soon as the patient is deemed fit. In the meantime, tight endoscopic surveillance should be offered for early detection of rectal dysplasia/cancer. Apart from dysplasia and cancer some patients with DR suffer from symptomatic proctitis that may require a completion proctectomy.

Surgically fit patients, without dysplasia or cancer in their pathology report, who underwent a subtotal colectomy usually request for restoration of their bowel continuity, with either an ileorectal anastomosis (IRA) or an ileal pouch anal anastomosis (IPAA). ${ }^{(66)}$ DR patients who suffer from symptomatic proctitis and are candidates for reconstruction should be aware of the 
future risk of IRA failure. Instead, patients should undergo a completion proctectomy and choose another form of reconstruction. ${ }^{(7,67)}$

IRA was first introduced by Stanley Aylett more than 50 years ago ${ }^{(68)}$. It was the standard surgery for treatment of UC for years. Unlike Brooke's ileostomy, patients got to keep their bowel continuity and continence. IRA surgery can be performed as one step surgery at the same session of subtotal colectomy or as two step surgery. Especially in severely ill patients a stepwise approach is recommended, with a subtotal colectomy and ileostomy as a first step followed by an ileorectal anastomosis later. ${ }^{(6)}$ IRA surgery, compared with IPAA, is not as complex as a procedure, with shorter operating time and requires minimal pelvic dissection and causes minimal blood loss. However, concerns are raised about a possible future risk of cancer in the remaining rectal tissue. ${ }^{(69)}$ 

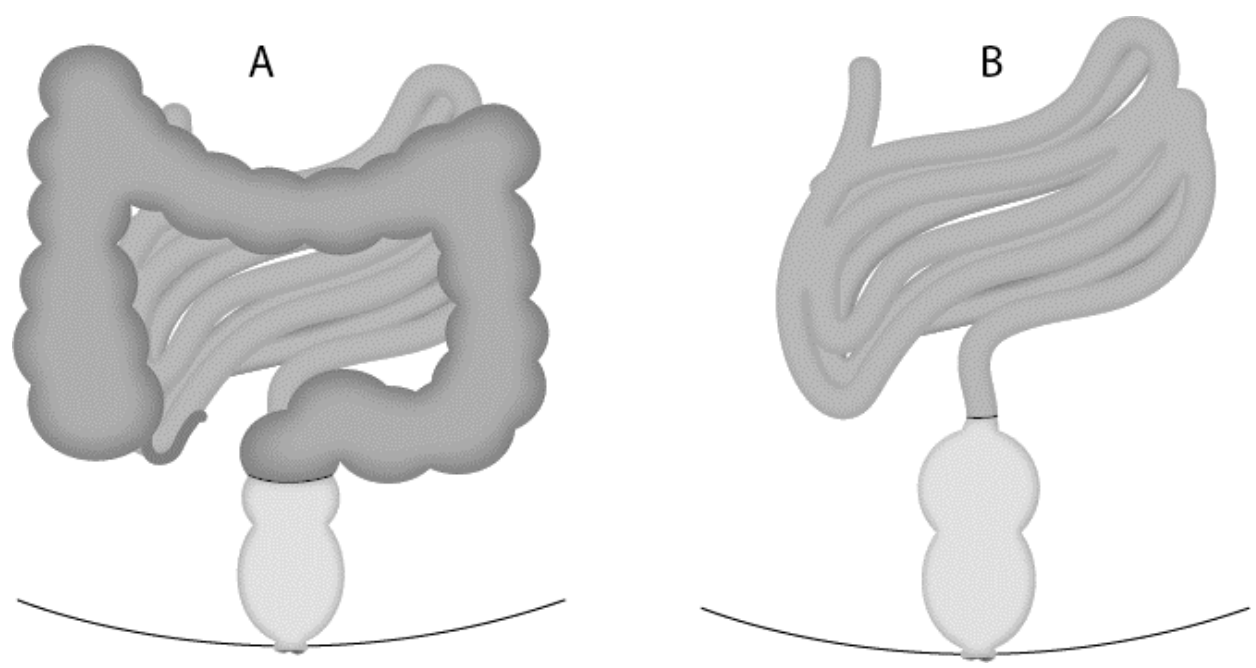

Figure 6: Ilea-rectal anastomosis (IRA).

A)The colon parts marked in red will be resected (subtotal colectomy) leaving the rectum behind. B)The ileum anastomosed to the remaining rectum.

Reprinted with permission from Springer international Publishing AG, from the book: The Ileoanal Pouch 2019; Chapter 14, page 174, figure $14.1 \mathrm{a}$ and $\mathrm{b}$.

Proctitis is another not uncommon problem that concerns UC patients reconstructed with an IRA. Patients who suffer from proctitis complain from abdominal pain, urgency, diarrhea and bleeding. A previous study reported that $22 \%$ of UC patients with a grossly normal rectum at time of subtotal colectomy developed proctitis, of which $11 \%$ underwent a completion proctectomy for IRA failure. ${ }^{(70)}$ A previous study reported that $27 \%$ of UC patients will manifest IRA failure and will require a secondary proctectomy, of which two thirds were due to proctitis. ${ }^{(71)}$

The search for a novel surgery that preserves continence and avoids the risk of rectal cancer was on. The year 1969, Prof Nils Kock fashioned a reservoir constructed of the small bowel. It had the advantage of preserved continence while having an external opening on the abdominal 
wall. To reconstruct the reservoir, an intestinal loop was opened longitudinally and sutured together to form U shaped limbs. Then the reservoir's corner was sutured to the abdominal wall, and an efferent limb was added. Initially, continence was obtained from the rectus abdominis muscle. Later, continence was maintained through a nipple valve formed by retrograde intussusception of the efferent intestinal limb into the pouch. ${ }^{(72)}$ Despite continence, several surgeons reported the valve slippage and detachment from the abdominal wall. Further modifications were developed in order to staple the nipple valve by Kock, Stein and Fazio. ${ }^{(73-}$ ${ }^{75)}$ Addition of synthetic material was discouraged due to risk of fistulas. ${ }^{(76)}$ Barnett introduced another type of valve, the isoperistaltic valve from the afferent limb, to overcome valve slippage. Furthermore, a conduit of ileum that forms a living intestinal collar was added around the reservoir outlet. When the reservoir is full the pressure increases inside the collar, subsequently maintain continence of the pouch. This modification is called the Barnett continent ileostomy reservoir (BCIR). Further modification was added by stapling the valve into the reservoir and moreover placing the stapling at the same line of pouch sutures. ${ }^{(75,77)}$ Trials to avoid valve slippage lead to the development of the new $\mathrm{T}$ shaped reservoir with a serosal lined anti reflux mechanism is reported by Kaiser. ${ }^{(78)}$ However, this T shaped reservoir requires proper evaluation before it is widespread. 


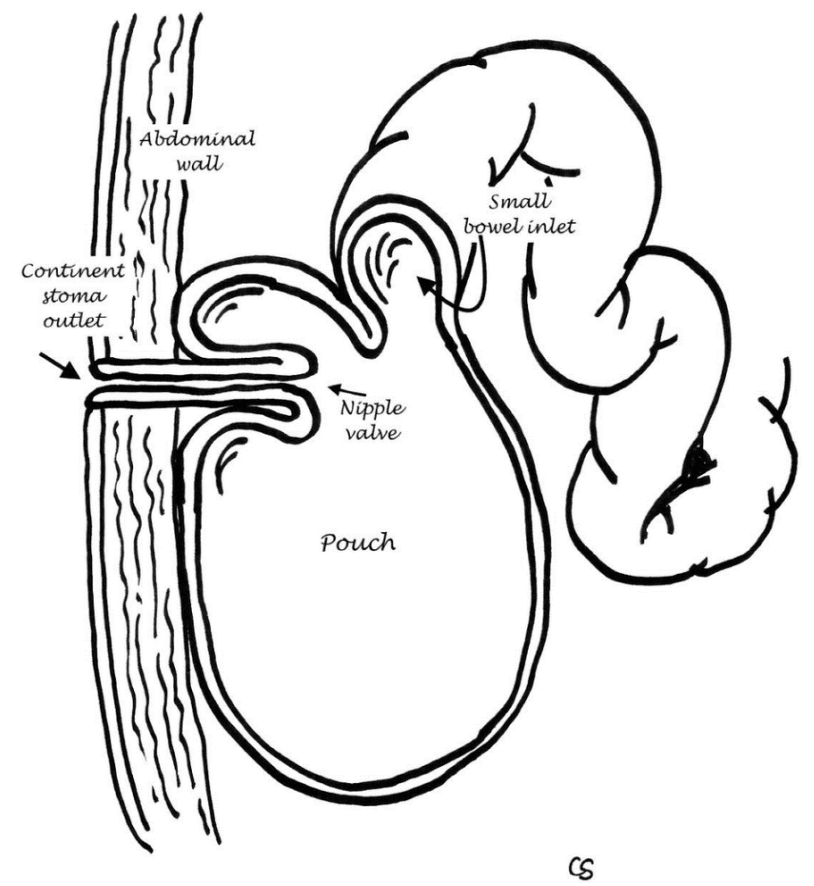

Figure 7: A simplified drawing of the Kock pouch

Reprinted with permission from Springer international Publishing AG, from the book: The Kock pouch 2019; Chapter 4, page 36, figure 4.1.

There are several problems with continent ileostomy other than valve slippage. First, continent ileostomy requires proper training on catheter intubation for evacuation and a cooperative patient without any mental, physical or psychological obstacles. Second, continent ileostomy is contraindicated for patients with past/ family history of desmoid tumors due to risk of tumor recurrence. Third, it requires approximately $50 \mathrm{~cm}$ of small bowel to fashion a continent ileostomy. Therefore, patients with short bowel or those who underwent a pouchectomy of their pelvic pouch are not recommended to perform a continent ileostomy. ${ }^{(79,80)}$

Sir Alan Parks fashioned another surgical procedure that could maintain the natural anal route, 
maintain continence and discard most of the rectal tissue. Thus, he could minimize future risk of rectal cancer as well as restore the bowel stream via an ileal-pouch anal anastomosis (IPAA). $(6,81,82)$ Details of the procedure were first published in the British Medical Journal in 1978. ${ }^{(83)}$ Since then, IPAA has been the gold standard in most parts of the world. ${ }^{(84,85)}$
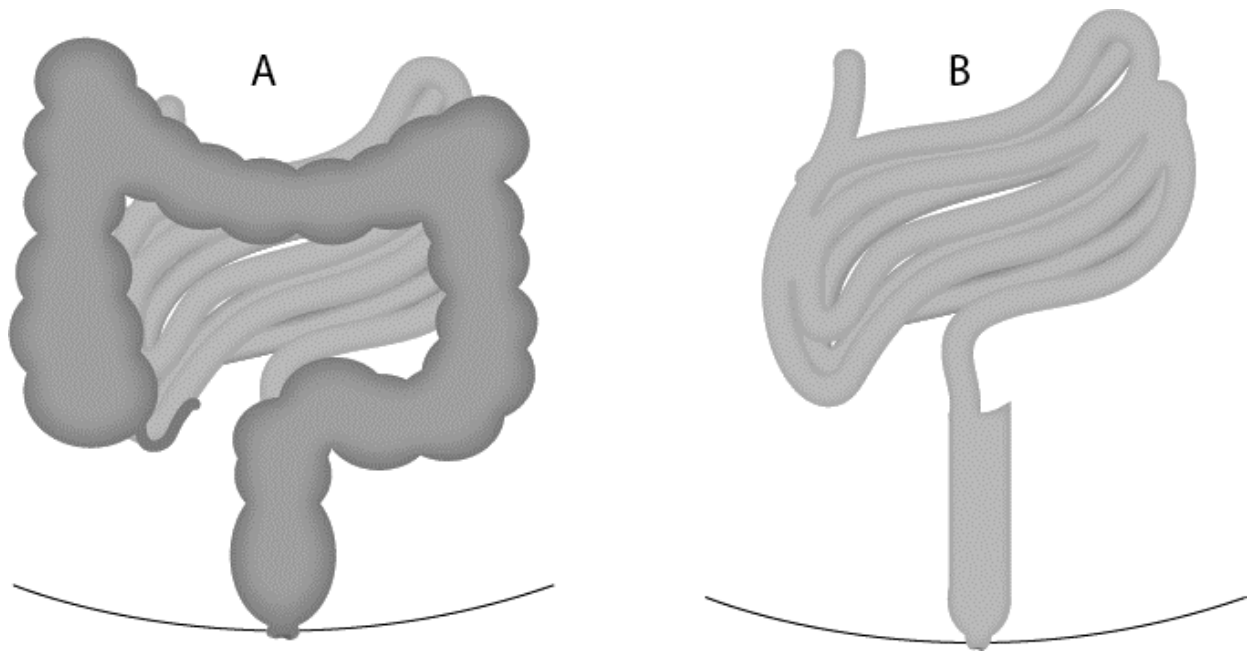

Figure 8: Ileal-pouch anal anastomosis (IPAA).

A) Colon and rectum (marked in red) will be surgically resected. B) formation of a $\mathbf{J}$ shaped pouch of ileum then anastomosis to the anal canal is performed.

Reprinted with permission from Springer international Publishing AG, from the book: The Ileoanal Pouch 2019; Chapter 14, page 174, figure $14.2 \mathrm{a}$ and $\mathrm{b}$.

Reconstruction with an IPAA may today be performed through an open or laparoscopic technique. Studies reported that there is no clear evidence that laparoscopic IPAA is superior to open IPAA regarding operative time, blood loss or postoperative hospital stay. ${ }^{(86,87)}$ They did not suffer from more postoperative comorbidities compared to open IPAA but they were able to close their ileostomy earlier. ${ }^{(86,88)}$ Additionally, another study reported that there was no difference regarding pregnancy rates after laparoscopic IPAA compared to conventional 
IPPA. ${ }^{(89)}$ One more study concluded that the rate of pregnancy in females with UC was higher in patients reconstructed with laparoscopic restorative proctocolectomy compared to those with a conventional restorative proctocolectomy. This is probably due to less bleeding with subsequent reduction of pelvic adhesions. ${ }^{(90)}$ Prospective large scale studies are required to determine the potential superiority of the laparoscopic approach.

Moreover, IPAA can be constructed in one step at the same session of the proctocolectomy, which may be safe for selected UC patients without severe disease activity, e.g. elective surgery in patients who are not steroids. ${ }^{(91)}$ IPAA can also be performed as a two- or three-staged procedure. The most common method in Sweden is a three-staged procedure with subtotal colectomy and end-ileostomy first. When the patient has recovered after approximately six months, a proctectomy is performed with creation of the IPAA and a diverting loop-ileostomy. The diversion is closed after approximately 3 months. It can also be performed as a two-stage procedure when proctocolectomy and IPAA is performed directly with a diverting loopileostomy, followed by closure of the ileostomy as in the three-stage procedure. Recently a modified two-stage procedure has been winning ground. In these cases, a subtotal colectomy and end-ileostomy is done first while the second step includes proctectomy with IPAA but without the use of a diverting ileostomy. Thus patients have shorter hospital stays and avoid the burden of a third surgery. ${ }^{(92)}$ A recent study concluded that patients with the modified twostage IPAA reported significantly lower anastomotic leaks, despite suffering from more severe UC activity and higher preoperative use of steroids. ${ }^{(93)}$ The advantage of the three-stage and the modified two-stage IPAA is that it can be performed in emergency settings as it allows time to improve the patients' nutritional status, treat anemia, and withdraw from immunomodulating medications before going through a more complex pelvic dissection with a high risk anastomosis. ${ }^{(92,94)}$ Other studies concluded that the three-stage IPAA is associated with more intraoperative hemodynamic instability and lower use of immune modulators. ${ }^{(95)} \mathrm{A}$ recent large 
scale study reported that there were no differences in morbidity or mortality of patients with a three-stage versus two-stage IPAA. ${ }^{(96)}$

Surgeons have developed several shapes of the reservoir the S-, the J- and the W-reservoir. These reservoirs can be performed via hand-sewn (with or without mucosectomy) or via transanal stapling. Studies that compared the stapled and hand-sewn anastomosis reported no significant differences in early postoperative complications or bowel function. ${ }^{(97)}$ However, some studies reported more night seepage and incontinence of liquid stools in the handsewn group $^{(98)}$ and that a stapled anastomosis is superior regarding continence, need of using pads, restrictions in the diet as well as restrictions in work and social life. ${ }^{(87,99)}$ Additionally, there were no significant differences between the three shapes of pouches regarding the early/late postoperative complications, e.g. anastomotic leak or strictures, infection of the wound or pelvic sepsis, pouchitis or pouch failure. ${ }^{(100,101)} \mathrm{S}$-shaped and W-shaped pouches manifested lower frequency of defecation and thus less need for anti-diarrheal treatment. ${ }^{(102)}$ Surgeons who prefer the S-pouch, mostly handsewn, motivate that because the efferent limb fits well in the anal canal and the body lies above the levator muscles of the pelvic floor. ${ }^{(87)}$ Surgeons prefer Jpouch because it can be formed by staplers, thus minimize operative time, and requires less intubation to evacuate. However, the blunt end of the J-pouch can be distorted because it gets forced in the muscular anal canal. On the another hand, K-reservoir is time-consuming, complex procedure that requires experienced hands for optimal results. ${ }^{(103)}$ However, it has somewhat better long term functional outcomes than J- reservoir. ${ }^{(104)}$

It is known that IPAA patient satisfaction is dependent on their ano-rectal function and sexual function. ${ }^{(105-107)}$ It is also known that female UC patients reconstructed with an IPAA suffer from reduced fecundity compared to other UC patient. ${ }^{(108)}$ Few small-sized studies suggested that the laparoscopic reconstruction of an IPAA was not different from the conventional IPAA regarding the reduction of intraoperative bleeding, operative time and postoperative 
morbidities ${ }^{(86,87)}$ but may have less impairment on female fertility. ${ }^{(89,90,109)}$ However, large scale studies are required to draw firm conclusions.

Recently, IRA has regained popularity in Sweden. ${ }^{(110)}$ Part of the reason why IRA regained popularity is that it lacks some of the disadvantages of the IPAA. The surgical procedure is less complicated, less time consuming and involves minimal bleeding. Additionally, IRA does not impair bowel function or sexual function. IRA patients have even better functional outcomes compared to IPAA patients if strict selection criteria were followed. ${ }^{(111)}$ Evidence has showed that fertility and fecundability of young UC patients with an IRA is not worse than the general population, especially after the introduction of laparoscopy. ${ }^{(12)}$ Accordingly, IRA could function as an interim procedure for young UC patients in order to postpone pelvic dissection required for an IPAA. ${ }^{(113)}$

However, IRA as a surgical option for UC patients comes with some concerns. Researchers argue that leaving behind rectal tissue can be problematic. A recent study concluded that UC patients have an increased risk of IRA failure, up to $27 \%$ specially if they were reconstructed for chronic refractory disease. ${ }^{(71)}$ On the contrary, another study concluded the risk of IRA failure to be $15 \%$ with minimal functional impairment observed. ${ }^{(114)}$ Additionally, researches hypothesize that persistent mucosal inflammation may trigger development of dysplasia or cancer in the remaining rectal mucosa. ${ }^{(3,6,69)}$ However, this was only investigated from tertiary care centers and large-scale population-based studies are required to draw firm conclusions.

When IRA fails, it is inevitable to recommend a completion proctectomy. Then rises an important question: could patients keep continence or not, i.e. end ileostomy? In case they request a secondary reconstruction there are two possibilities today, an IPAA or a Kock pouch (a continent ileostomy) The functional outcome of IPAA as a secondary reconstruction has been thoroughly studied in patients with Familial adenomatous polyposis (FAP) and both pouch 
survival and function were found to be similar to that of primary pouches. ${ }^{(115)}$ By contrast, to our knowledge no previous study compared the outcome of primary and secondary IPAA in UC patients. More studies are required to investigate the outcome of primary and secondary reconstructed IPAA in IBD patients in general and UC patients in specific. 


\section{Aims of the study}

I. To assess the risk and risk factors for rectal cancer in ulcerative colitis patients after colectomy and reconstruction with an IRA, an IPAA or without reconstruction in form of permanent ileostomy and diverted rectum in place.

II. To compare the colorectal cancer in IBD patients, with and without a PSC diagnosis, to non IBD controls regarding tumor incidence, tumor location as well as risk of synchronous and metachronous cancers after segmental resection.

III. To evaluate the association between the anorectal function and QoL between IRA and IPAA in ulcerative colitis patients and relate their mucosal inflammation, diagnosed via endoscopy and pathology reports, to the anorectal function.

IV. To estimate the survival of primary reconstructed IPAA and secondary reconstructed after a previous IRA in ulcerative colitis patients. 


\section{Methods}

\section{Registers}

A unique personal identification number was first introduced in Sweden in 1967 and since then assigned to cover all Swedish residents. This personal number permits the follow-up of patients in national registers, e.g. the Swedish Patient Register (NPR). The NPR was established in 1964-1965 to document individual hospital discharges. The discharge diagnoses are coded according to the International Classification of Diseases, seventh revision (ICD7) 1964-1968, eighth revision (ICD8) 1969-1986, ninth revision (ICD-9) 1987-1996, and ICD-10 thereafter. Each record corresponds to one in-hospital episode and contains information about date of hospital admission, main discharge diagnosis and up to seven concurrent diagnoses as well as treating department. The register also includes information about surgical procedures based on the "Klassifikation av operationer" (1964-1996) and the Swedish version of the NOMESCO (Nordic Medico-Statistical Committee) classification of surgical procedures since 1997. As health care service in Sweden is funded by the government and registration in the NPR is mandatory, Swedish hospitals began reporting to the register the year 1964 with complete national coverage since $1987^{(116)}$. A previous study estimated the completeness of the NPR to be $85-95 \%$. $^{(117)}$

The same unique personal number is also used to obtain individual information about the date and site of a diagnosis of dysplasia or cancer from the colon and rectum via linkage to the Swedish Cancer Register (SCR). The SCR was first introduced in 1958 and it is mandatory according to Swedish law to report to the register. It receives data about cancer diagnoses from clinical, morphological, laboratory as well as autopsy reports. ${ }^{(118,119)}$ Further, information about death due to cancer is reported in the Cause of Death Register. The 
completeness of Cause of Death Register was evaluated in a studies by Brooke et al and Johansson et al. Death due to cancer is well reported in most instances, such as breast cancer, because of the linkage to the National Cancer Register, while some other cancers are underreported e.g., pancreatic cancers. ${ }^{(118,120,121)(122)}$

\section{Patients}

Patients with a diagnosis of IBD after $1^{\text {st }}$ of January 1964 were identified from the patient registers (papers I, II and IV). From the Linköping University Hospital, we identified all UC patients operated with subtotal colectomy between the years 1992-2006 (paper III).

\section{Variables identification}

For papers I and II, we identified patients with a diagnosis of Ulcerative colitis (ICD7 572.20, 572.21, 578.03; ICD8 563.10, 569.02; ICD9 556*; ICD10 K51*). For paper IV, we identified UC patients as well as Crohn's disease patients (ICD 7 572.00, 572.09; ICD 8 563.00; ICD 9 555*; ICD 10 K50*) and indeterminate colitis (ICD 7 572.30; ICD 8 563.98, 563.99; ICD 9 558; ICD $10 \mathrm{~K} 52.3)$. Even though the ICD-9 era was little problematic because there was no code for IC diagnosis, we selected patients with the code (558) as IC only if it was followed by another IBD diagnosis on a second occasion, otherwise the patient was excluded. For the patient to keep an UC, CD or IC diagnosis he/she should not have any other IBD discharge diagnosis. If the patients had a first diagnosis of an IC and later diagnosed as either having $\mathrm{UC}$ or $\mathrm{CD}$, he/she will be accepted as an $\mathrm{UC}$ or $\mathrm{CD}$ patient respectively. An IBD-Mixed diagnosis (IBD-Mix) was determined as a final diagnosis if the patient had a combination of UC, CD or IC. The last registered diagnosis was used for patients having multiple registrations with different IBD diagnoses. The first registered date of an IBD diagnosis in the register was accepted as the date of debut of IBD. 
We investigated PSC as an independent risk factor for cancer in (papers I and IV). This was not easy because there are no specific codes for PSC in the ICD-10, neither was there in the ICD-9, 8 or 7 . We identified patients with a cholangitis code associated with an IBD diagnosis as PSC patients, through the codes; ICD-7 (575.05 and 585.29), ICD-8 (575.05), ICD-9 (576B), and ICD-10 (K830A, K830). The date of PSC diagnosis was accepted as the date of hospitalization when PSC diagnosis is made.

We identified surgical procedures (papers I-IV), patients operated with subtotal colectomy without a concurrent anastomosis to the rectum (operation codes 4651, JFH10 or JFH11). We also identified the sub-cohorts of patients that had been operated with colectomy and an ileorectal anastomosis (IRA, operation codes 4650, JFH00, JFH01, JFC40 or JFC41) or an ileal pouch anal anastomosis (IPAA, operation codes 4654, 4823, JFH30, JFH33, JGB50 or JGB60).

\section{Paper specific methodology}

Paper I: The follow up started from the date of sub-total colectomy in the group of patients with a diverted rectum and the date of reconstruction (IRA or IPAA) for reconstructed patients. The follow up ended at the date of a rectal cancer diagnosis, proctectomy, death or emigration or the $31^{\text {st }}$ of December 2010, whichever comes first.

Paper II: The follow up started at the date of reconstruction of ileal-pouch anal anastomosis (IPAA), both the primary and secondary reconstructed. The follow up ended at the date of pouch failure, death or 31st of December 2010, whichever comes first. In order to understand the follow up, we stated some statistical definitions. A primary IPAA was defined as an IPAA with no previous IRA while a secondary IPAA was defined as an IPAA constructed subsequent to a previous IRA. 
We defined pouch failure as the removal of the IPAA (i.e. pouchectomy), construction of a diverting ileostomy, including a continent ileostomy, more than 30 days after the reconstruction of an IPAA. Patients with a redo IPAA after a previous IPAA were excluded from the study after their first failure.

Paper III: UC patients reconstructed at Linköping University Hospital with either an IRA or an IPAA were invited to undergo an evaluation of their anorectal function and their postoperative QoL. Those who agreed to take part signed the informed consent and answered the following validated questionnaires: Öresland functional score, SF-36, and the Short Health Scale (see appendix).

Three weeks later they were invited to an endoscopic evaluation of their reservoirs or rectums including multiple biopsies taken and sent for histopathological evaluation. The grade of endoscopic inflammation was evaluated according to the Baron-Ginsberg score (BG score). BG score is originally intended for evaluation of rectal mucosa in IRA. However, we chose to standardize the method for both IRA and IPAA (appendix 4).

Multiple biopsies were taken from the ileum, anastomotic site, upper rectum, and ampulla in case of IRA and from the ileum proximal of the pouch, from upper and lower part of the pouch itself, and the rectal cuff in case of IPAA. The pathologist reported the grade of inflammation from all segments, coded as no, mild, moderate or severe inflammation. A global grade of inflammation was estimated for each patient from the highest grade of inflammation found in any part of the reservoir or rectum. Presence of dysplasia or polyps were reported. We investigated for possible associations between the severity of endoscopic and histopathologic inflammation and the anorectal function and quality of life in IRA and IPAA patients. 
Paper IV: IBD patients with and without a concomitant PSC diagnosis (IBD/PSC+ and IBD/PSC-) were assigned four matched controls, according to age, gender, time at diagnosis and place of residence at time of diagnosis. We needed to investigate the impact of an IBD diagnosis with a concomitant PSC diagnosis on colorectal cancer location. In order to do this we identified this data for each individual from the Cancer Register using the following SCR coding: right sided colon (ICD-7: 153.4 and 153.0, denoting cancers occurring in the appendix, caecum or ascending colon), transverse colon (ICD-7: 153.1), descending colon (ICD-7: 153.2), sigmoid colon (ICD-7:153.3) and rectum (ICD-7:154.0). Colon cancer with unspecified location was identified by the following ICD code (ICD-7:153.9).

Follow up started at the date of PSC diagnosis for the IBD patients with a concomitant PSC, the date of IBD diagnosis for IBD patients without a concomitant PSC and the matching date for the controls. The follow up ended at the date of first cancer diagnosis, colectomy, death or $31^{\text {st }}$ of December 2014 for the colorectal cancer diagnosis, whichever came first.

Moreover, we needed to identify the risk of synchronous and metachronous cancers in the IBD/PSC- and IBD/PSC+ compared to controls. Since we had data only about tumour location and the date of diagnosis, it was not possible to identify the distance between the cancers to be more than $4 \mathrm{~cm}$ in case of synchronous. To overcome this problem, we defined synchronous cancers statistically as two or more CRCs occurring at a time interval equal to or less than 180 days. Meanwhile, metachronous cancer were defined as two or more CRC occurring at a time interval more than 180 days and were in different location of the colon and rectum then the first tumour. The follow up in such cases started at the date of segmental colectomy and ended at the date of synchronous cancer or the date of metachronous cancer, total colectomy, death, emigration or $31^{\text {st }}$ of December 2014, whichever comes first. 


\section{Statistics}

We reported patient's demographics via mean and SD (papers I, III and IV) and median and IQR (in paper II, and some analyses in paper III). We used some non-parametric tests: Mann Whitney U test to test the difference between reconstruction groups (paper III) and the Chi squared test as well as the Fisher's exact to test differences in proportions (papers I, II and IV).

We used the Kendall-tau correlation and ordered logistic regression (paper III) to analyse the possible association between the answered questionnaires and the grade of inflammation reported on the endoscopic/pathologic examination.

In papers ( I, II and IV ), we performed several types of survival analysis: Cox proportional hazard to identify possible risk factors using both uni- and multivariable analyses. Kaplan Meier survival curves, cumulative hazard and log rank tests were used to identify differences in survival between the studied groups (papers I, II and IV). Standardized incidence ratios (SIR) were estimated using age-, sex- and period-specific incidence rates for the Swedish population obtained from the web-based statistical service of the Swedish National Board of Health and Welfare (paper I). Incidence rate ratio (IRR) of risk factors for CRC in IBD patients were reported after matching to non-IBD controls according to age, sex, periodspecific and residence (paper IV). ${ }^{(123)}$ Net survival and excess hazard of death were estimated for CRC patients with/without PSC diagnosis compared to controls (paper IV).

\section{Handling missing data}

Paper III: Some patients did not answer all the questions of the questionnaires of the SF-36. If less than one third of a questionnaire was left unanswered, the missing items scores were calculated through- person specific mean score calculated based on non-missing scores. ${ }^{(124)}$ If more than one third of the questions were left unanswered, the questionnaire was excluded 
from the analysis. Seven patients declined to undergo endoscopy and macroscopic assessment. Moreover, four endoscopy reports were missing (of which one pathology report was found)while two more pathology reports were missing after complete endoscopy.

All tests were 2-sided, and the results were considered statistically significant if $p$ value was $<0.05$ or at $95 \%$ CI. All calculations were performed using STATA program versions 15 (StataCorp. 2015. Stata Statistical Software: Release 15. College Station, TX: StataCorp LP, USA).

\section{Ethical approval}

All studies were approved be Linköping regional ethics review board (Dnr 2011/419-31, papers I, II and IV) and (Dnr:M127-07, paper III). 


\section{Results}

Detailed results are mentioned in the respective papers. Here only the most important findings will be highlighted.

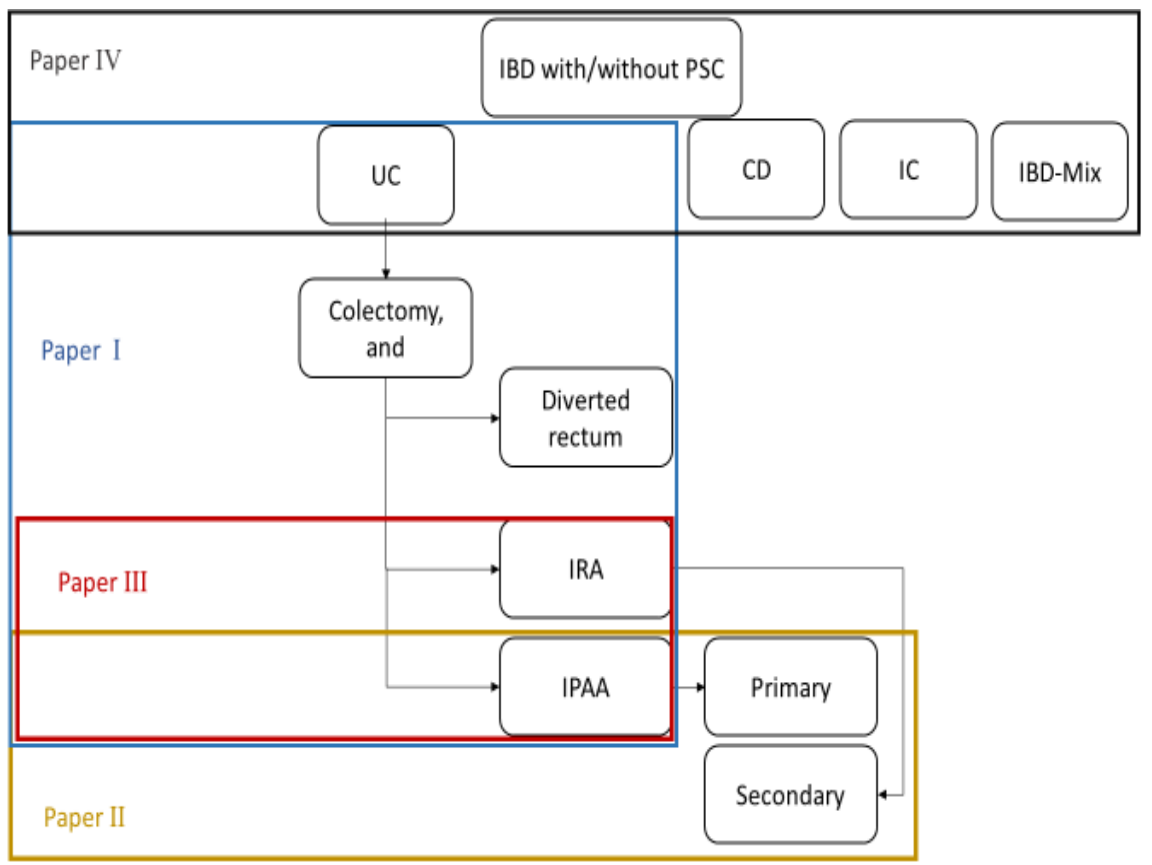

Figure 9 :The studied populations in the thesis.

Data for all studies were nation-wide obtained from the National Patient register, except for paper III were data was obtained from the patient charts at Linköping University hospital. 


\section{Paper I}

During the study period from 1964 to 2010 , a total of 63,795 patients were diagnosed with

Ulcerative colitis. Of which 7,889 (12\%) patients underwent subtotal colectomy. Rectal cancer occurred in total of $46(0.8 \%)$ of the 5,886 patients having had a sub-total colectomy (table 1).

Table 1 Demographics of the studied population (paper I) of 5,886 patients with ulcerative colitis that were operated with subtotal colectomy during 1964-2010 ${ }^{\S}$

\begin{tabular}{|l|c|c|c|}
\hline & IRA (n=1112) & IPAA (n=1,796) & DR* (n=4,358) \\
\hline Male Sex No. (\%) & $637(57.3)$ & $1120(62.2)$ & $2630(60.3)$ \\
\hline $\begin{array}{l}\text { Age at Ulcerative Colitis diagnosis } \\
\text { (years mean (SD)) }\end{array}$ & $35.1(15.9)$ & $31.7(12.2)$ & $38.5(18.0)$ \\
\hline $\begin{array}{l}\text { Age at Colectomy. (years mean } \\
(\mathrm{SD}))\end{array}$ & $40.6(15.7)$ & $36.4(11.9)$ & $42.1(17.6)$ \\
\hline $\begin{array}{l}\text { Follow up (years mean (range) }) \\
\text { Total follow up time (years) }\end{array}$ & $8.6(0.02-45.1)$ & $12.2(0.04-25.4)$ & $5.7(0.003-45.5)$ \\
\hline Rectal cancer No. $(\%)$ & 9,603 & 21,975 & 24,994 \\
\hline $\begin{array}{l}\text { Cum. risk for RC at 5 years \% }(95 \% \\
\text { CI) }\end{array}$ & $0.3(0.1-1.1)$ & 0.0 & $0.2(0.1-0.5)$ \\
\hline $\begin{array}{l}\text { Cum. risk for RC at 10 years \% } \\
(95 \% \text { CI) }\end{array}$ & $1.6(0.7-3.3)$ & $0.1(0.01-0.6)$ & $0.5(0.3-1.1)$ \\
\hline $\begin{array}{l}\text { Cum. risk for RC at 20 years \% } \\
(95 \% \text { CI) }\end{array}$ & $5.6(3.3-9.3)$ & $0.1(0.01-0.6)$ & $2.2(1.4-3.6)$ \\
\hline SIR (95\% CI) & $8.7(5.6-13.4)$ & $0.4(0.0-2.5)$ & $3.8(2.6-5.7)$ \\
\hline
\end{tabular}

*Patients going through ileorectal anastomosis, proctocolectomy, ileal pouch anal anastomosis or completion proctectomy at a later stage are included as patients with de-functioned rectum until proctectomy or reconstruction took place. ${ }^{\S}$ Patients who had proctocolectomy from the start or rectal cancer at time of colectomy were not included in this table. 


\section{Ileorectal anastomosis}

Rectal cancer (RC) occurred in 20 out of 1,112 IRA patients. The relative risk for RC was 8.7, while the absolute risk was $1.8 \%$. One third of the patients restored with an IRA who developed rectal cancer had a concomitant primary sclerosing cholangitis (PSC). The hazard ratio of developing rectal cancer in UC patients with a concomitant PSC was 5.95 (95\% CI 2.34-15.13, $p<0.001)$ in univariate analysis, and $6.12(95 \%$ CI $2.33-16.03, p<0.001)$ in multivariate analysis compared to those without a PSC. It is noteworthy that most cancers occurred after 10 years of follow up after an IRA (Table 1, figure 10).

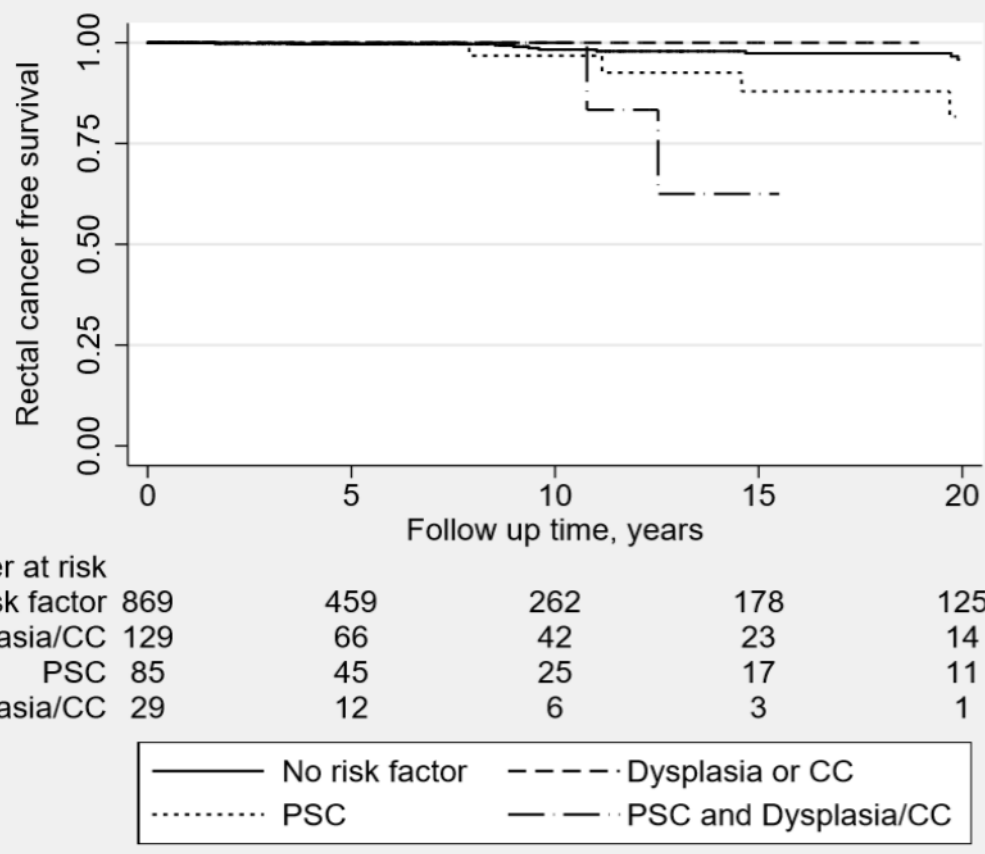

Figure 10: Kaplan Meier curve investigating the effect of possible risk factors on the rectal cancer free survival $(p$ value $<0.001)$ 


\section{Ileal-pouch anal anastomosis}

One UC patient out of 1,796 reconstructed with an IPAA developed RC. The relative risk to develop cancer was 0.4 (95\% CI 0.0-2.5) when compared to the general population while the absolute risk was $0.06 \%$. This RC patients was a young male diagnosed with UC at the age of 14 and was reconstructed at the age of 16 . At the age of 25 , he developed cancer in the rectal remnant of the pouch without a previous history of severe dysplasia, cancer or PSC. He died one year later due to advanced rectal cancer.

\section{Diverted rectum}

Twenty-five out of 4,358 UC patients with an intact but diverted rectum developed RC. The relative risk for DR patients to develop RC was 3.8 compared with the general population, while the absolute risk was $0.6 \%$. History of severe dysplasia or colon cancer before colectomy was the only risk factor detected in univariate analysis HR was 4.64 (95\%CI 1.3815.58, $p=0.0013)$ and in multivariate analysis HR was 3.67 (95\%CI 1.01-13.37, $p=0.049)$. Most cancers occurred after 15 years of follow up after date of subtotal colectomy (Table 1, figure 11). 


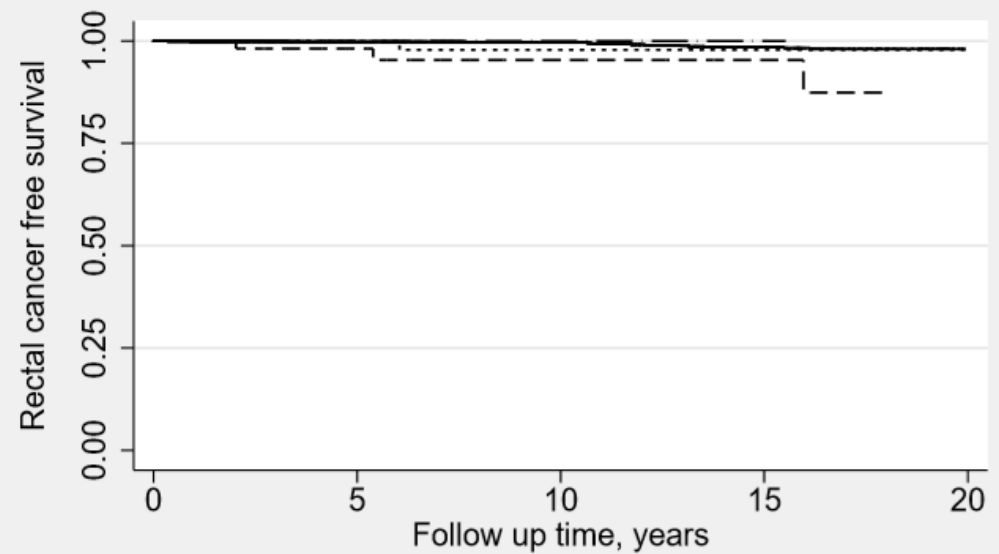

Number at risk

No risk factor 4046

Dysplasia/CC 126

PSC 162

PSC \& Dysplasia/CC 24

$\begin{array}{cccc}1340 & 865 & 506 & 320 \\ 37 & 21 & 12 & 7 \\ 53 & 27 & 18 & 8 \\ 7 & 4 & 4 & 3\end{array}$

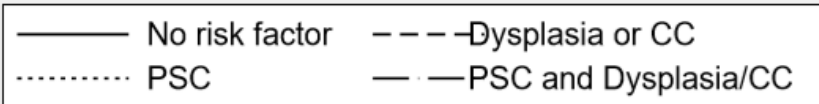

Figure 11: Kaplan Meier curve analysing the effect of possible risk factors on the rectal cancer free survival of ulcerative colitis patients with an intact and diverted rectum.

$(p$ value $<0.001)$

\section{Paper II}

From the same cohort of UC patients, IPAA was the primary reconstruction in 1,720 (95.8\%) patients, and the secondary reconstruction after a previous IRA in 76 (4.2\%) patients. As expected, time from colectomy to reconstruction was longer in case of secondary IPAA than primary IPAA $(p<0.001)$. Failure occurred in a total of 109 IPAA patients (103 primary and 6 secondary) after a total follow up of 21,202 person-years. There was no difference in survival of primary reconstructed IPAA compared to secondary reconstructed IPAA (Table 2, figure 12) 
Table 2: The demographics of the studied population paper II

\begin{tabular}{|l|c|c|c|c|}
\hline & Total IPAA & Primary IPAA & Secondary IPAA value $^{\mathrm{a}}$ \\
\hline Number of patients & 1796 & 1720 & 76 & - \\
\hline Number per year period (\%) & & & & \\
$1964-1979$ & 0 & 0 & 10 & - \\
$1980-1989$ & $197(47.0)$ & 187 & 29 & - \\
$1990-1999$ & $897(81.2)$ & 868 & 37 & - \\
2000-2010 & $702(54.3)$ & 665 & 54.0 & 0.13 \\
\hline Male sex (\%) & 62.3 & 62.6 & 38.6 & 0.31 \\
\hline Age at reconstruction & 36.9 & 36.8 & $(28.8-48.0)$ & \\
median (IQR) & $(28.2-45.8)$ & $(28.2-45.8)$ & 6.1 & 0.002 \\
\hline Duration of UC at reconstruction & 3.2 & 3.1 & $(2.2-11.7)$ & \\
(years) & $(1.2-8.2)$ & $(1.2-8.1)$ & 1.9 & $<0.001$ \\
\hline Time from colectomy to & 0.4 & 0.4 & $(0.8-1.8)$ & \\
reconstruction (years) & $(0.0-1.0)$ & $(0.0-1.0)$ & 10.0 & 0.12 \\
\hline Follow up duration (years) & 12.4 & 12.6 & $(3.5-15.9)$ & \\
\hline Failure n (\%) & $(6.5-16.6)$ & $(6.7-16.6)$ & $6(8)$ & 0.50 \\
\hline Survival of IPAA, \% (95\%CI) & $109(6.1)$ & $103(6.0)$ & & \\
5 years & $96(95-97)$ & $96(95-97)$ & $94(85-98)$ & \\
10 years & $94(93-95)$ & $94(93-96)$ & $92(81-97)$ & $0.38^{\pi}$ \\
20 years & $92(90-93)$ & $92(90-93)$ & $88(73-95)$ & \\
\hline
\end{tabular}

a Primary versus secondary IPAA. $\pi$ Log rank test

(IPAA) Ileal pouch anal anastomosis, (CI) confidence interval, (IQR) Interquartile range, (UC) Ulcerative colitis 


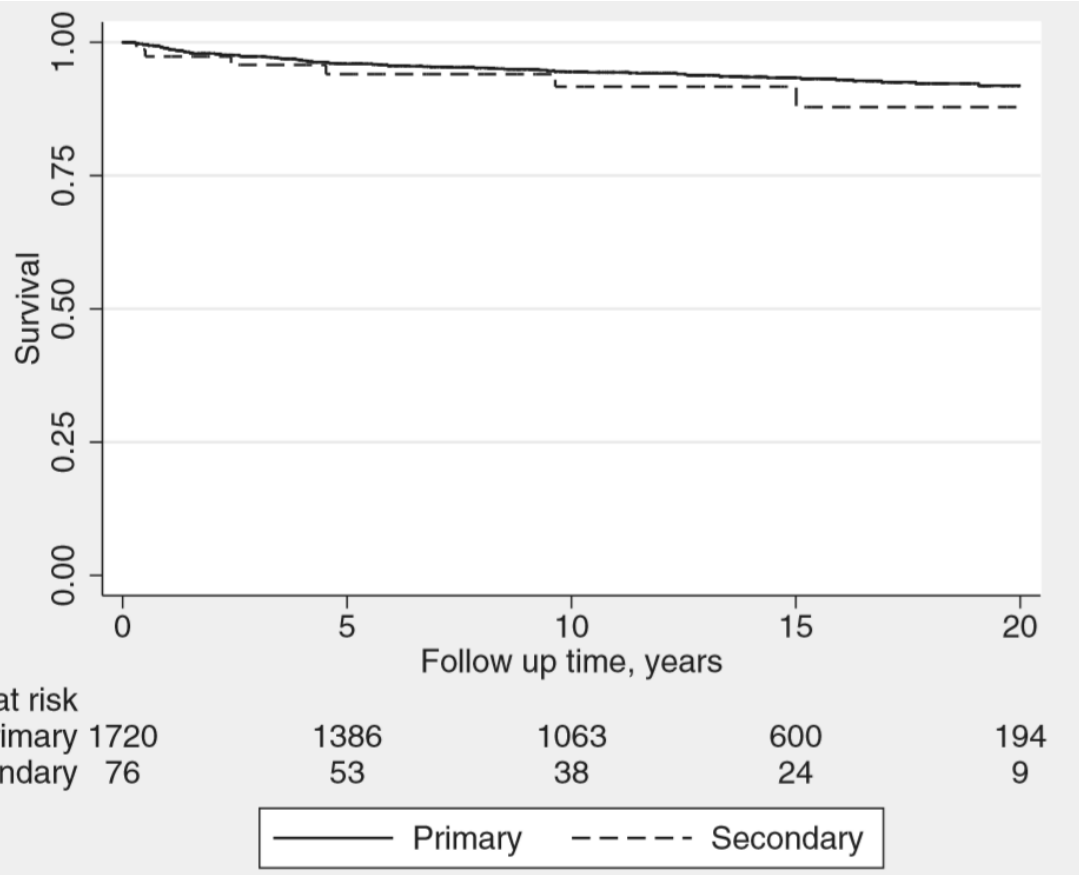

Figure 12: The risk of IPAA failure was similar after primary and secondary reconstruction. ( $p$ value 0.38$)$

\section{Paper III}

In the study, 38 IRA and 39 IPAA patients answered the questionnaires. Most of them were males $29(52.7 \%)$ in IRA and $26(47.3 \%)$ in IPAA. There was no difference in age at diagnosis between IRA patients 25.8 (IQR 6.4-57.2) and IPAA patients 25.2 (IQR 9.1-42.0, $p=0.910)$ or age at reconstruction with IRA was $33.1(10.3-75.2)$ and reconstruction with IPAA was $35.2(18.9-58.9, p=0.424)$. The median follow-up after the restorative procedure was 12.1 (range 3.5-19.4) years. 68 patients underwent endoscopic evaluation. (Figure 13). 


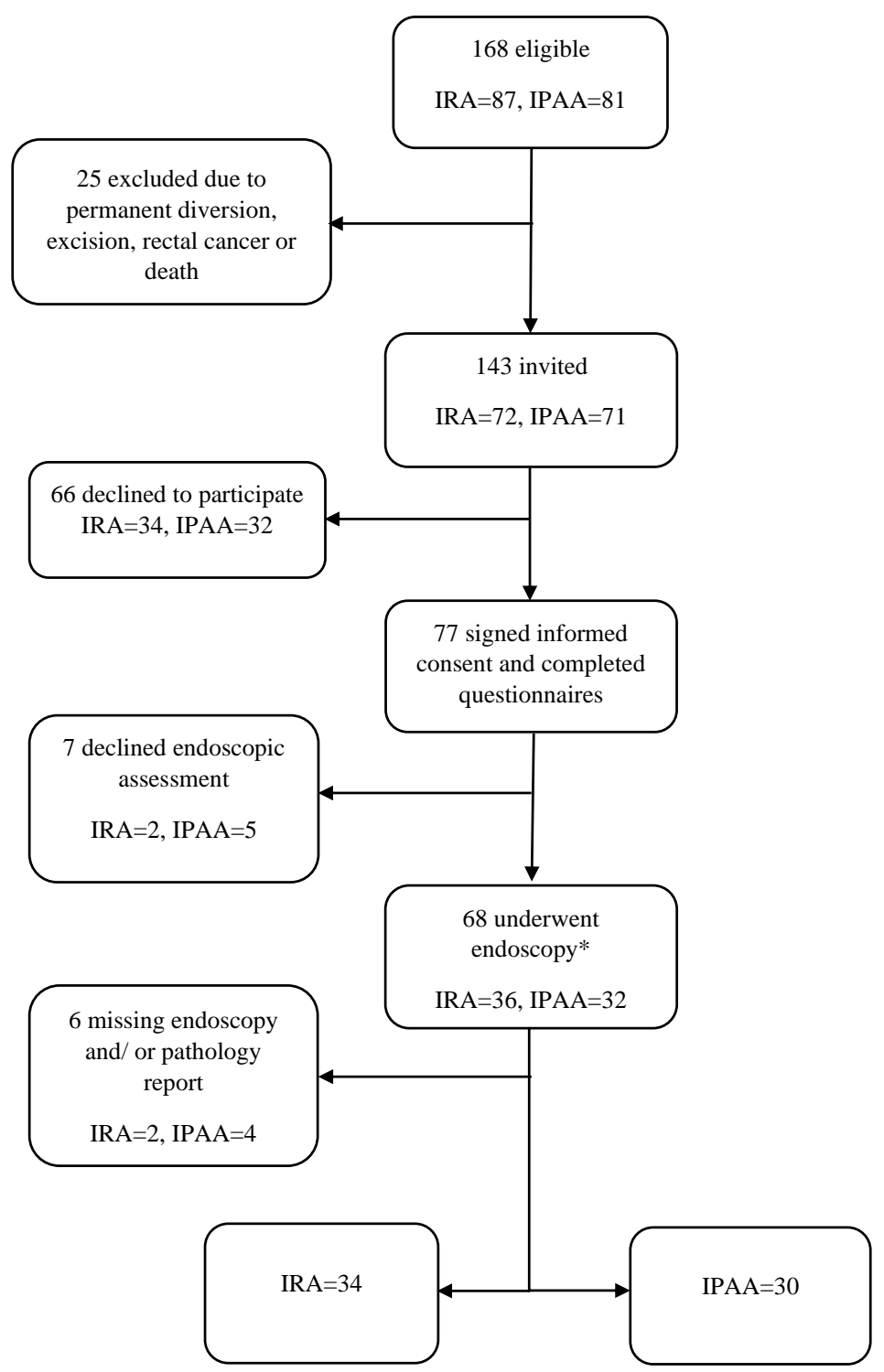

Figure 13: Flow chart of the included study participants in Paper III.

* Data of the 77 patients were included in demographic table and the questionnaire analyses. However, they were not included for the test of the associations. 


\section{The questionnaires}

\section{$\underline{\text { Ano-rectal function (the Öresland Score) }}$}

Patients with IRA had better function according to the Öresland score with a median overall score of 3 (IQR 2-5) compared to 10 (IQR 5-15) for IPAA (p<0.001) (Figure 14). Only three (7.9\%) IRA patients had a total Öresland score $\geq 8$ compared to $21(53.8 \%)$ IPAA patients, $(p<0.001)$.

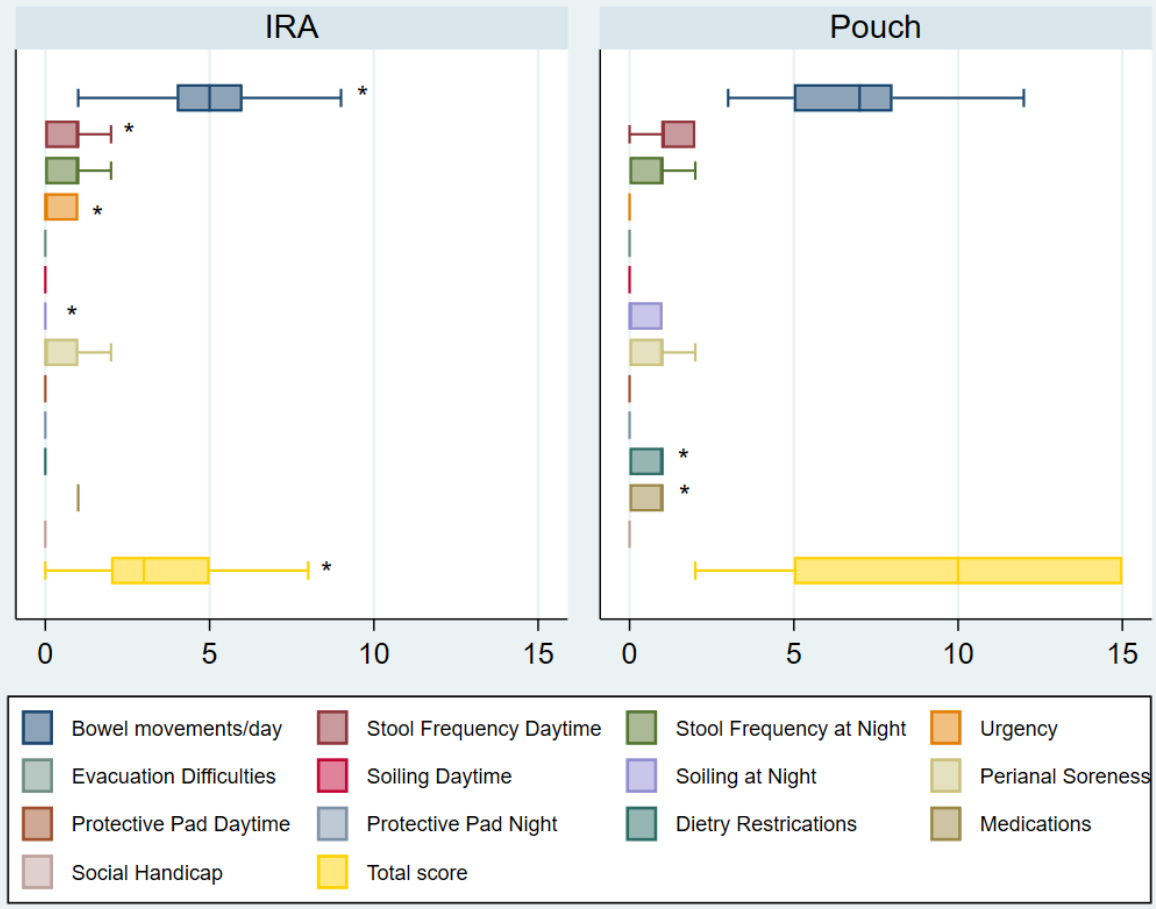

Figure 14: Boxplots of the medians and CI 95\% of Öresland score in UC patients operated with IRA and IPAA.

Zero score is the best possible score and 15 is the worst possible score. ${ }^{*} p$ value $<0.05$. 
On the other hand, thirteen IRA patients $(34.2 \%)$ showed a trend towards urgency compared to six $(15.4 \%)$ IPAA patients $(p=0.057)$ and the number of IRA patients who received medications (occasionally or continuously) was $32(84.2 \%)$ compared to $22(56.4 \%)$ of the IPAA patients $(p=0.008)$. Twenty-eight IRA patients received mesalamine alone or combined with another medication (three combined with prednisolone, two with hydrocortisone foam, and one patient combined with both).

\section{SF-36}

The mean SF-36 score for the role limitation due to physical problems was worse for IRA patients compared to IPAA patients, 77.6 and $92.3(p=0.043)$. There was also a trend towards worse transition of mental health in IRA patient with a mean of 74.2 in compared to 85.3 in IPAA $(p=0.053)$ (Figure 15). 


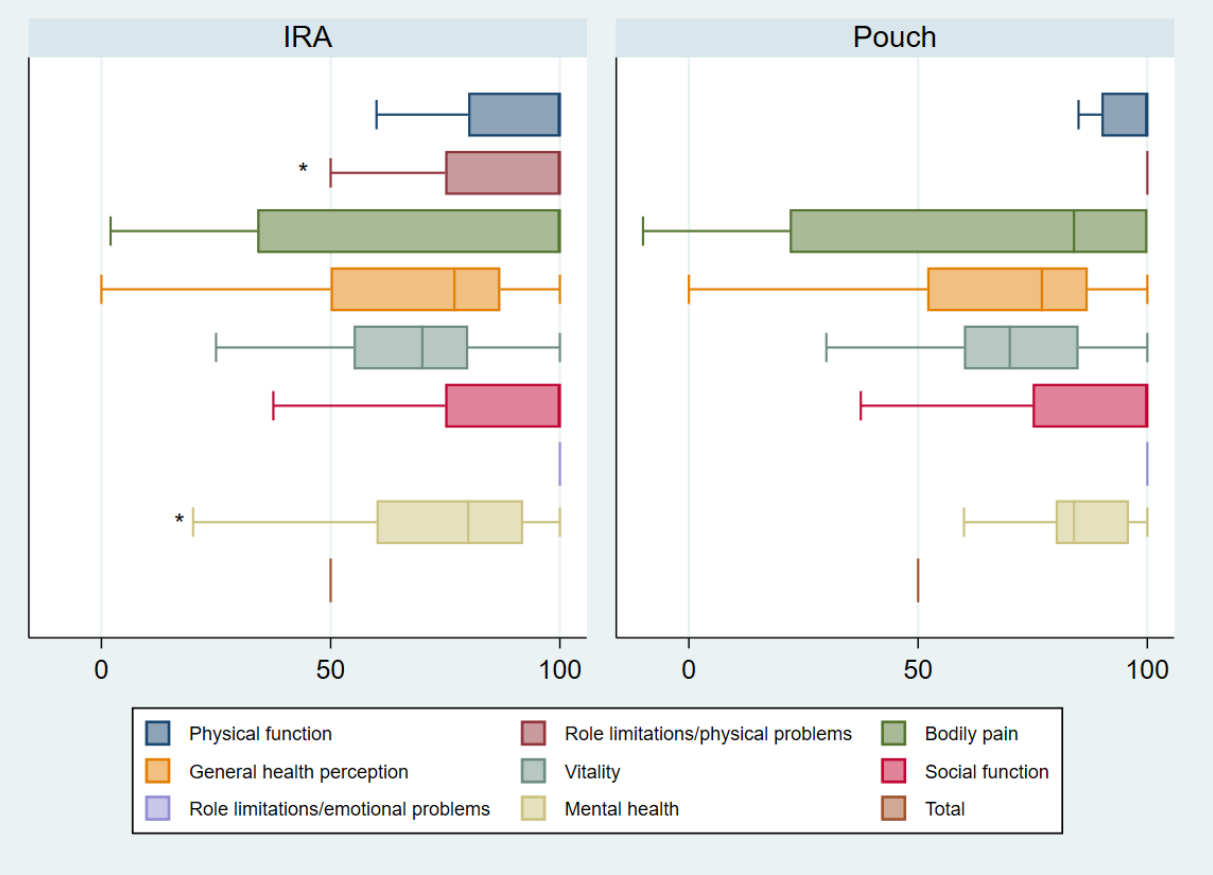

Figure 15: Boxplots of the medians and 95\% confidence interval of SF-36 in ulcerative colitis patients operated with IRA or IPAA.

Zero represents the best possible and 100 the worst possible score. ${ }^{*} p$ value $<0.05$.

\section{Endoscopy \& biopsy results}

On endoscopy, six (18\%) IRA patients had a Baron-Ginsburg (BG) score of two or higher, compared to $11(37 \%)$ IPAA patients ( $p=0.273)$. On histopathology, $21(60 \%)$ IRA patients had moderate to severe inflammation in the rectum whereas $24(77 \%)$ of the IPAA patients displayed histological signs of pouch inflammation $(p=0.454)$ (Table 3$)$. 
Table 3: Results of pathology reports: histological grades of inflammation, types and site of dysplasia and number of polyps.

\begin{tabular}{|c|c|c|c|}
\hline & IRA & IPAA & $p$-value \\
\hline Endoscopy* & $\mathrm{n}=34$ & $\mathrm{n}=30$ & \\
Baron Ginsburg score & & & 0.173 \\
0 & 7 & 6 & \\
1 & 21 & 13 & \\
2 & 5 & 11 & \\
3 & 1 & $\mathrm{n}=30$ & 0.091 \\
Pathology reports ${ }^{+}$ & $\mathrm{n}=35$ & 0 & \\
Inflammatory grades & & 6 & \\
None & 10 & 17 & \\
Mild & 11 & 7 & 0.099 \\
Moderate & 10 & 1 at ileum & \\
Severe & & 2 at rectal cuff & \\
Cellular changes & 1 at anastomosis & 1 rectal mucosa & \\
Low grade dysplasia & & & \\
Hyperplasia & & & \\
Squamous metaplasia & & & \\
\hline
\end{tabular}

\footnotetext{
*Missing endoscopy reports from two IRA. Missing both endoscopy and pathology report from two IPAA patients. So (IRA $n=34$, IPAA $n=30$ )

${ }^{+}$Found an additional IRA pathology report without endoscopy report. Missing pathology report from two IPAA patients. So (IRA n=35, IPAA n=30).
}

\section{Association between mucosal inflammation and function}

There was a positive correlation between Öresland score and endoscopic grades of inflammation (BG score) for IPAA patients only (tau. $0.28, p=0.006$ ) but not for IRA patients. For the IPAA patients the strength of the association was further analysed with ordered logistic regression. This shows that the Öresland score is strongly impaired when BG score increases, with OR $1.3(\mathrm{CI}-0.6-3.2, \mathrm{p}=0.188)$ for grade 1 to OR 3.4 (CI 0.8-6.1, $p=0.012$ ) for grade 2 . 
By contrast, there was no correlation between the results of pathology reports and the total Öresland score neither in IRA $(p=0.740)$ or IPAA $(p=0.197)$ patients.

\section{Association between macroscopic and microscopic grades of inflammation}

There was a weak correlation between grades of inflammation reported macroscopically using BG endoscopic score and microscopically through pathology reports (tau. $0.19, p=0.01$ ) in all patients. When studying correlation between BG score and pathology reports in IPAA and IRA, respectively, there was a correlation in the previous (tau. $0.26, p=0.021$ ) but not the latter group (tau. $0.16, p=0.125$ ). 


\section{Paper IV}

After 10,645,342 person-years of follow up, a total of 2,854 (2.2\%) CRC were diagnosed out of 127,578 IBD patients compared to $8,107(1.3 \%)$ CRC diagnosed out of 610,120 matched controls. CRC occurred in $4.5 \%$ of IBD/PSC+ compared to $2.2 \%$ in IBD/PSC- (figure 16).
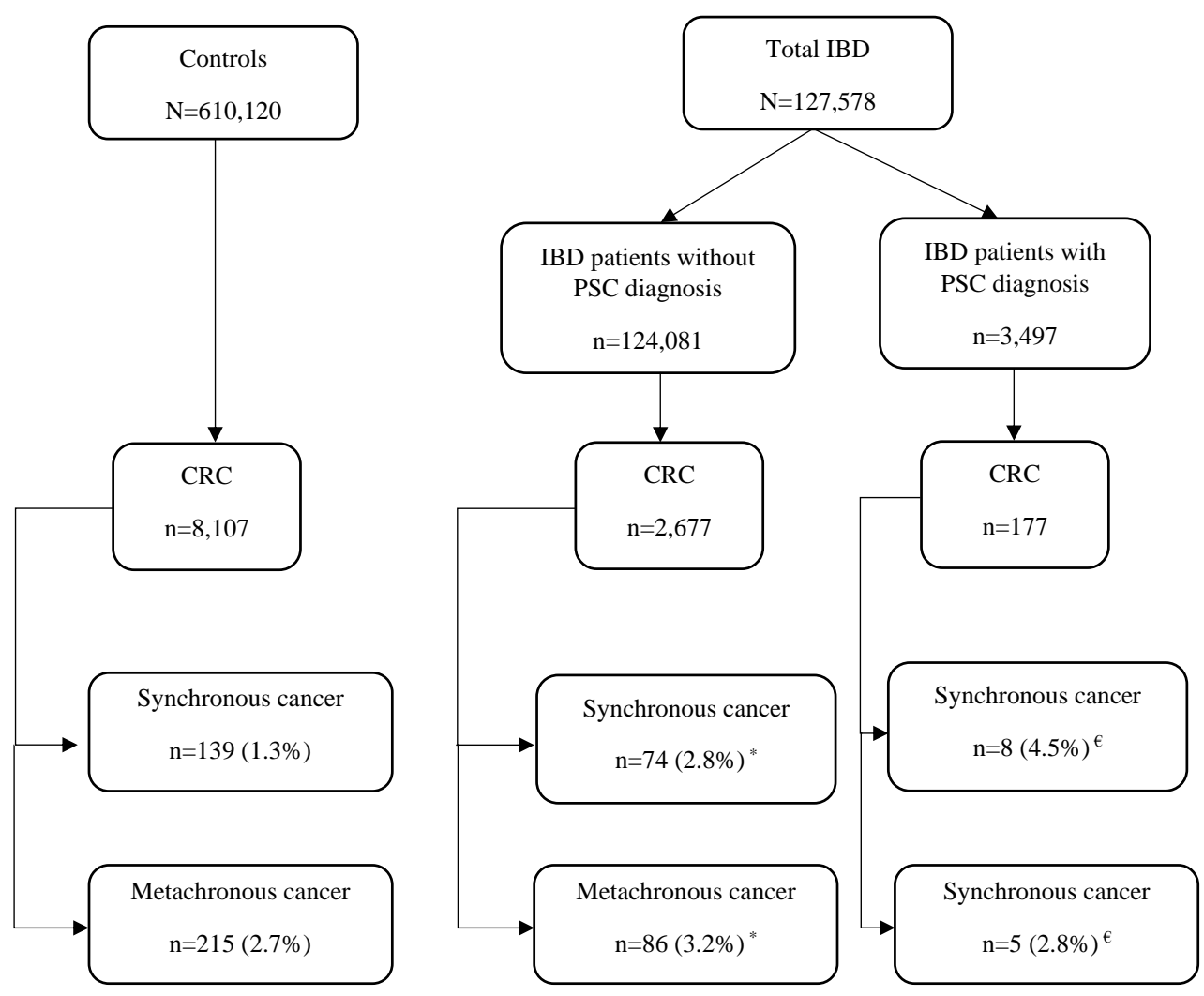

Figure 16: Flow chart of the studied population in paper IV.

${ }^{\epsilon}$ out of IBD/PSC+ with primary cancer. " out of IBD/PSC- patients with primary cancer

IBD Inflammatory Bowel Disease, PSC primary sclerosing cholangitis, CRC colorectal cancer 


\section{Risk factors for Colo-rectal cancer in IBD patients}

IBD patients with PSC+ had a significantly increased risk of CRC compared to those without a PSC diagnosis. The IRR of IBD/PSC+ was 6.6 (95\% CI; 5.2-8.4), IBD/PSC- was 1.6 (95\% CI; $1.5-1.7 ; p<0.001)$.

\section{Additional risk factors}

Patients diagnosed before the age of 20 years had the lowest risk in univariate analysis, HR $0.10(95 \%$ CI 0.09-0.12; $p<0.001)$ as well as multivariate analysis, HR 0.08 (95\%CI 0.07$0.10 ; p<0.001)$. However, compared to controls of the same age the youngest IBD patients had the highest lifetime relative risk (IRR 63.52, 95\% CI 39.46-101.39 for PSC+ and IRR 13.87, 95\% CI 9.72-20.09 for PSC-).

Patients diagnosed with an IBD diagnosis at the age of 60 or older had the highest risk to develop CRC, HR 3.24 (3.07-3.41, $p<0.001$ ), taking middle aged patients (40-59 years) as reference value, whereas they had only a slightly higher risk compared with controls (IRR 1.92, 95\% CI 1.27-2.77 for PSC+ and IRR 1.63, 95\% CI 1.54-1.74 for PSC-) (table 4). 
Table 4: Incidence rate ratio of age groups to develop colo-rectal cancer for inflammatory bowel disease patients with and without a concomitant diagnosis of primary sclerosing cholangitis, all compared with controls without an IBD diagnosis.

\begin{tabular}{|c|c|c|c|c|c|c|c|c|}
\hline \multirow{2}{*}{$\begin{array}{c}\text { Age at } \\
\text { IBD } \\
\text { diagnosis }\end{array}$} & \multicolumn{4}{|c|}{ IBD/PSC- } & \multicolumn{4}{|c|}{ IBD/PSC+ } \\
\hline & $\begin{array}{c}\text { Number } \\
\text { of } \\
\text { patients }\end{array}$ & $\begin{array}{c}\text { Number } \\
\text { with } \\
\text { CRC }\end{array}$ & IRR & $95 \% \mathrm{CI}$ & $\begin{array}{l}\text { Number } \\
\text { of patients }\end{array}$ & $\begin{array}{c}\text { Number } \\
\text { with } \\
\text { CRC }\end{array}$ & IRR & $95 \% \mathrm{CI}$ \\
\hline $0-19$ & 15,252 & 111 & 13.87 & $9.72-20.09$ & 960 & 34 & 63.52 & 39.46-101.39 \\
\hline $20-39$ & 45,036 & 458 & 2.72 & $2.41-3.06$ & 1,281 & 65 & 13.62 & $10.28-17.74$ \\
\hline $40-59$ & 32,987 & 709 & 1.40 & $1.27-1.54$ & 770 & 49 & 4.33 & $3.08-5.91$ \\
\hline $60-$ & 30,806 & 1,399 & 1.63 & $1.54-1.74$ & 486 & 29 & 1.92 & $1.27-2.77$ \\
\hline
\end{tabular}

Patients compared to controls from the Swedish population. $(p<0.001)$.

IBD/PSC- Inflammatory bowel disease without a concomitant diagnosis of sclerosing cholangitis

IBD/PSC+ Inflammatory bowel disease with a concomitant diagnosis of sclerosing cholangitis

IRR Incidence Rate Ratio

Interaction between PSC+ and age at IBD showed the highest impact on the relative CRC risk for patients diagnosed with IBD before the age of 20 (HR 5.35, 95\% CI 3.28-8.67, $p<0.001$ ), decreasing gradually with increasing age. Consequently, the cumulated cancer risk reached a high level also in the youngest PSC+ patients after 30 years of follow up compared to PSCand controls. Whereas there was a smaller difference in relative risk for CRC among PSCand PSC+ compared to controls for the older patients (40-59 and over 60) they had the highest cumulative risk for the first 20 years after diagnosis (figure 17). 


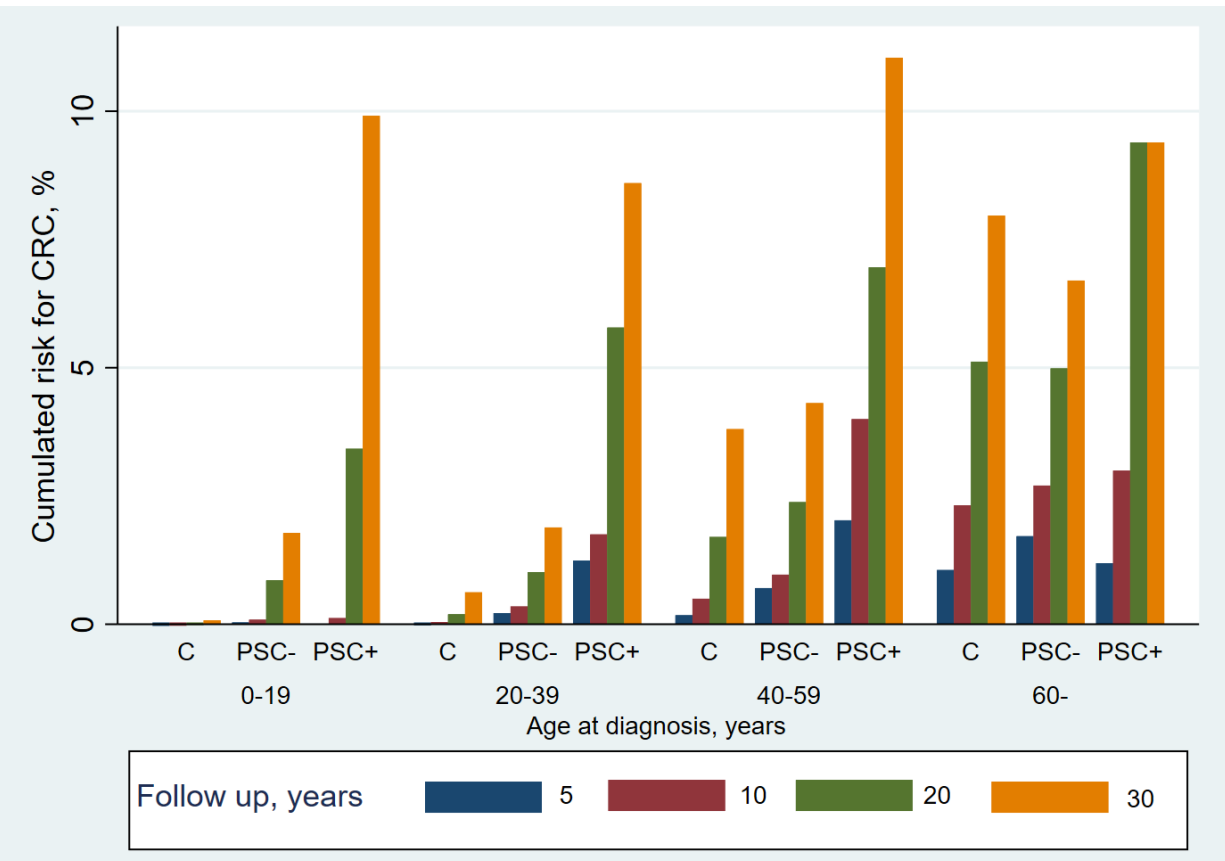

Figure 17: Cumulative risk of developing CRC in patients with inflammatory bowel disease. with and without primary sclerosing cholangitis as well as matched controls according to age of IBD diagnosis and length of follow up.

\section{IBD subtype}

In univariate analysis, the IC subtype had the highest risk to develop CRC (HR 2.54; 95\% CI 2.0-3.22; $p<0.001$ ) followed by UC (HR 1.9; 95\%CI 1.77-2.03; $p<0.001)$, IBD-Mix and finally CD. In multivariate analysis, IBD-Mix patients had the highest risk, HR 2.8 (95\% CI 1.94-2.45; $p<0.001$ ), while CD had the lowest risk 1.46 (95\% CI 1.33-1.60; $p<0.001)$ compared to controls. 


\section{The tumour location}

IBD/PSC+ patients developed $177 \mathrm{CRC}$, of which 65 (36.7\%) were in the caecum/ascending colon, followed by 36 (20.3\%) transverse colon and finally 32 (18.1\%) rectal cancers.

However, the HR for caecal/ascending cancer in IBD/PSC+ was 8.3 (95\% CI 6.4-10.7) while descending colon cancers were the 11.9 (95\% CI; 6.7-21.4), ( $p$ value <0.001).

Rectum was the most common tumour location in IBD/PSC- patients $(31.1 \%)$, followed by the caecum/ascending $(27.3 \%)$ and the sigmoid colon (15.5\%). Similarly, the most common CRC location in controls was rectum $35.2 \%$, followed by caecum/ascending $22.6 \%$ and sigmoid colon $22.9 \%$. In relative numbers, HR for rectal cancer in IBD/PSC- patients was 1.4(95\% CI; 1.2-1.5) compared to IRR of caecal/ascending IRR 2.4 (95\% CI; 2.1-2.6) $(\mathrm{p}<0.001)$ (figure 18)

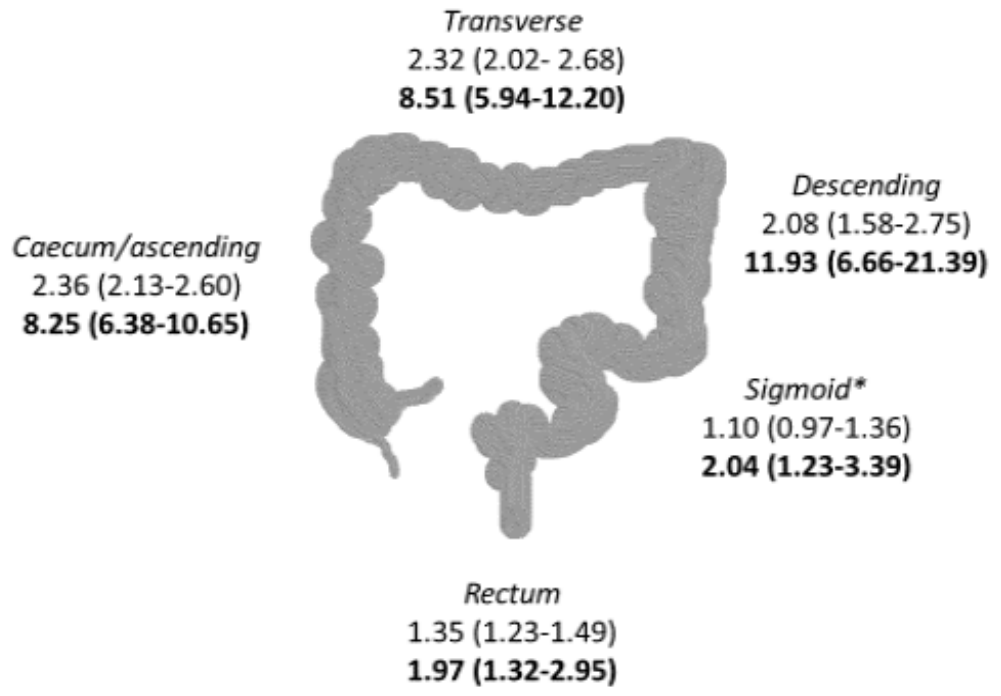

Figure 18: Hazard ratio and (95\% CI) of cancer distribution in inflammatory bowel disease patients with and without primary sclerosing cholangitis compared to controls from the Swedish population. $p$ value was $<0.001$ in all except the Sigmoid colon $(* p$ value $=0.147$ in IBD/PSCpatients and 0.006 in IBD/PSC+). IBD/PSC- in regular and IBD/PSC+ in Bold. 


\section{Synchronous cancers}

Synchronous cancers occurred in $8(4.5 \%)$ out of 177 PSC+ patients. Meanwhile $69(2.6 \%)$ out of 2,677 PSC- patients and $132(1.6 \%)$ out of 8,107 controls developed a first synchronous cancer, of which four PSC- and five controls developed a second synchronous cancer.

\section{Colectomy and metachronous cancer}

The cumulative risk for colectomy at 10 and 20 years for the PSC+ was $16.5 \%$ and $28.3 \%$ compared to $8.3 \%$ and $11.4 \%$ in PSC-. Moreover, the cumulative risk to develop metachronous cancer at 10 and 20 years for PSC+ was (1.0\% and 9.3\%) compared to PSC(4.3\% and $10.5 \%)$ and controls (3.0\% and $6.9 \%)$.

Metachronous cancer occurred in five (8.5\%) out of 177 PSC+ patients, of which three after sub-total colectomy in UC patients and two after segmental colectomy (one CD and one IBDMix patients). On the other hand, 82 (4.1\%) out of 1,981 PSC- patients developed a first metachronous cancer, $76.8 \%$ were after segmental colectomy (table 5). Metachronous cancer occurred in 208 controls, however, we had no data about potential colectomies in controls. 
Table 5: Type of resection in IBD patients diagnosed with metachronous cancers classified by sub-diagnoses.

\begin{tabular}{|l|c|c|c|c|c|c|c|}
\hline \multirow{2}{*}{ Type of first resection } & \multicolumn{4}{|c|}{ IBD/PSC- } & \multicolumn{3}{|c|}{ IBD/PSC+ } \\
\cline { 2 - 9 } & UC & CD & IC & IBD-Mix & UC & CD & IBD-Mix \\
\hline No colectomy & 5 & 1 & 0 & 1 & 0 & 0 & 0 \\
\hline Subtotal colectomy & 9 & 5 & 1 & 4 & 3 & 0 & 0 \\
\hline Caecum/ascending & 11 & 14 & 3 & 7 & 0 & 0 & 1 \\
\hline Transverse & 3 & 1 & 1 & 0 & 0 & 0 & 0 \\
\hline Descending & 1 & 0 & 0 & 0 & 0 & 0 & 0 \\
\hline Sigmoid & 1 & 5 & 0 & 1 & 0 & 0 & 0 \\
\hline Transverse/descending & 0 & 1 & 0 & 0 & 0 & 0 & 0 \\
\hline Descending/sigmoid & 3 & 0 & 0 & 1 & 0 & 0 & 0 \\
\hline Rectum & 0 & 0 & 0 & 0 & 0 & 1 & 0 \\
\hline Total & 36 & 27 & 5 & 14 & 3 & 1 & 1 \\
\hline
\end{tabular}

However, we detected that PSC- patients developed more metachronous cancers than PSC+. Eleven out of the eighty-two PSC- patients developed metachronous cancer after subtotal colectomy. Rectal cancers occurred after subtotal colectomy in eight PSC- patients (4 UC, 1 CD and 3 IBD-Mix). Surprisingly, 44 (53.7\%) of IBD patients developed metachronous cancers after a previous segmental colonic resection due to CRC (17 UC, 16 CD, 3 IC and 8 IBD-Mix). Of these 7 patients developed a metachronous rectal cancer after segmental colectomy (4 UC, 2 CD and one IBD-Mix). Similarly, UC patients with a diverted rectum who underwent subtotal colectomy for colonic dysplasia/or cancer, had 4 times increased risk to develop rectal cancer compared to those who had a subtotal colectomy for and a diverted rectum for any reason other than dysplasia/cancer. 


\section{Discussion}

From this thesis and previous reports, we can conclude that IRA is a safe surgical option for selected ulcerative colitis patients. ${ }^{(1,3,111,113,125,126)}$ We have also identified a group of UC patients who probably should not be offered an IRA as they are less suitable, mainly due to the risk of developing CRC.

In our study, UC was mostly diagnosed in young females before the age of 20 (26\%) or after the age of $60(28 \%)$. Regarding males, the risk to get a UC diagnosis before 20 years was $28 \%$ and was $26 \%$ after the age of 60 years. Recent studies detected that females before the age of 10 years had the high risk to get a UC diagnosis compared to males, then the risk is equals until the age of 45 years then the risk lowers for females. ${ }^{(127,128)}$ In approximately $12 \%$ of cases, patients will require surgery in the form of subtotal colectomy and an ileostomy. It is important for young patients to keep their continence, good bowel function, fertility, and QoL without compromising patients' safety. Rectal cancer is the number one concern that causes patients, as well as surgeons, to choose an IPAA.

From the first paper, the relative risk to develop rectal cancer after an IRA reconstruction is $8.9 \%$ and was $0.06 \%$ for IPAA reconstruction. Thus, IPAA is safer than IRA in ulcerative colitis. However, the absolute risk of rectal cancer in IRA was $1.8 \%$ at a mean follow up of 8.6 years and the cumulative risk was $1.6 \%$ and $5.6 \%$ at 10 and 20 years after receiving the IRA respectively. ${ }^{(129)}$

Additionally, in Sweden routine endoscopic evaluations with multiple biopsies start early after IRA reconstruction with an annual interval. It has proved valuable for evaluation of rectal mucosa and early detection of dysplasia/cancer. ${ }^{(130)}$ The procedure itself is well tolerated and takes a short time to perform with a low complication rate. On the other hand, 
routine pouch endoscopy after an IPAA has been shown less valuable due to the very low risk of dysplasia and is at the time reserved for complicated or high-risk cases. ${ }^{(5),(131)}$

The second concern on the patient's list is proctitis. In the present studies, we detected that $17.6 \%$ of IRA patients suffered from moderate to severe macroscopic inflammation in their rectal mucosa compared to $36.7 \%$ of patients reconstructed with an IPAA. Other studies reported higher incidence of proctitis of $32 \%$ in case of IRA ${ }^{(3)}$, as well as acute pouchitis up to $50 \%{ }^{(132)}$, probably due to our small sample. The incidence of pouchitis varies in literature: One study reported that $60 \%$ of UC patients with a previous acute pouchitis will suffer from a relapsing course of pouchitis. ${ }^{(132)}$ Other studies reported that $10-30 \%$ of UC patients developed a chronic unremitting form of refractory pouchitis. ${ }^{(133,134)}$ Unfortunately, we could not investigate possible risk factors for proctitis or pouchitis. In conclusion, the frequency of proctitis was lower than pouchitis both in our study and in the literature. The clinical effect of this finding is however not clear.

In the same study, we detected that the moderate to severe microscopic inflammation existed in $60 \%$ of IRA patients and $77 \%$ of IPAA patients. Macroscopic evaluation of rectal mucosa underestimated the severity of inflammation. In IRA, the frequency of microscopic inflammation was six times higher than detected on macroscopic evaluation of the rectal mucosa. This explains the poor association between the macroscopic and microscopic picture of inflammation for IRA patients. ${ }^{(135)}$ Meanwhile, the microscopic examination of pouches detected two times more frequent inflammation than detected on macroscopic evaluation of IPAA. A possible explanation is that rectal mucosa is more tolerant to faecal matter, so it requires a severe inflammation to manifest macro/microscopically while small intestinal mucosa is more vulnerable to faecal matter. This suggests that to achieve clinical remission from proctitis for IRA patients, the histological cure should be the target. 
At Linköping University Hospital, IRA patients receive prophylactic anti-inflammatory medication with topical amino-salicylic acid (5-ASA) as a standard of care. This is a treatment that works well for proctitis and has a possible cancer-protective effect. ${ }^{(1,6,113,136)}$ It is well tolerated with few side effects, ${ }^{(137)}$ and could reduce the risk of IRA failure and proctectomy due to severe proctitis. ${ }^{(7,138,139)}$ On the other hand, patients who suffer from chronic or relapsing pouchitis may require treatment with systemic anti-inflammatory drugs which are less tolerable and with more side effects. ${ }^{(140)}$

The third concern about the IRA is anorectal function. From the third study, we concluded that IRA patients have a somewhat better anorectal function compared with IPAA patients. The Öresland score was in favour of IRA patients, except for the more frequent use of medications and a trend towards increased urgency. ${ }^{(113)}$ In case of IRA, rectal mucosa is intact, and the stretch receptors are preserved, thus urgency is frequently reported. ${ }^{(141)}$ However, IPAA patients suffered less from urgency and the use of medications. Instead, they complained of leakage and incontinence. A previous study reported that large pouch volume and compliance correlated with the frequency of defecation in IPAA patients. ${ }^{(142)}$ In the case of IPAA, only a small cuff of the rectum is present. Thus, the small bowel of a pouch lacks rectal stretch receptors that warn against the rising volume of pouch contents, consequently, leakage may occur.

Additionally, IPAA patients showed a strong association between impaired function, according to the Öresland score, and the increased severity of endoscopic inflammation reported on BG score. Similarly, Sunde et al concluded that the poor-functioning pouch patients significantly suffered from more macro- and microscopic inflammation. ${ }^{(107)}$ However, we could not find a similar association between poor function in IRA and the BG score, probably due to few patients with a total Öresland score of more than 8 . 
Regarding the QoL, there were no differences between IRA and IPAA patients evaluated with SF-36 or SHS, ${ }^{(111)}$ but IRA patients suffered from more limitation regarding their physical functioning. They also reported worse transition of mental health during the last year after IRA compared to IPAA seemingly when evaluated with the SF-36. The only logical explanation to this may be related to urgency as patients may be afraid to engage in physical activities in fear of an unexpected bowel leakage or that it causes discomfort. This may in turn affect their mental health.

The fourth concern is what happens in the case of IRA failure. To answer that question, we need to illustrate some facts:

- The IRA failure rate is reported to be similar or somewhat higher than that of IPAA in non-randomized studies. ${ }^{(6,143)}$ The estimated cumulative failure rates after five and ten years were $10.1 \%$ and $24.1 \%$ for IRA and $6.1 \%$ and $18.6 \%$ for IPAA. ${ }^{(6)}$ Uzzan et al estimated IRA failure rates of $27 \%$ and $40 \%$ at 10 and 20 years after reconstruction, respectively. They reported that two-thirds of IRA failure occurred due to proctitis and in one third due to neoplasia. ${ }^{(71)}$ Another study reported that the cumulative failure rates were $5.2 \%, 15.8 \%$, and $18.0 \%$ after 1,3 , and 5-years of IRA reconstruction in 799 UC patients. ${ }^{(143)}$ In our second study, IRA failed at $23.8 \%$ while primary IPAA failed at $6 \%$ but we did not investigate neither the time points of failure nor could we identify the causes of failure for IRA and IPAA due to the lack of data in the NPR.

- In the case of IRA failure, a completion proctectomy can be performed. For patients who require to keep continence, they still have one more option, the IPAA. The outcome of an IPAA constructed after a previous IRA must be no worse than a de novo IPAA. In the second study, we detected no differences in pouch survival regardless if it was reconstructed primarily or secondarily. The only limitation was lack of reports on the function of the secondarily reconstructed IPAA. Thus, in a 
selected cohort of patients, another step can be added in the therapeutic ladder, possibly postponing the need for an indefinite ileostomy after IPAA failure. ${ }^{(144)}$ Despite the possibility to perform a redo pouch, the function and survival of a redo IPAA is worse than that of an IPAA performed at the same time as the completion proctectomy. ${ }^{(145)}$ Another option is to do a Kock pouch, either re-using the failed IPAA or creating a de novo Kock pouch ${ }^{(146)}$, but this procedure also has its limitations. $(147)$

Moreover, there are other well-known advantages of an IRA. An IRA can be performed in one step in concordance with subtotal colectomy or after subtotal colectomy, depending on the state of the patient as well as the indication of the colectomy. The possible explanation is that IRA is technically easier, it does not require the deep pelvic dissection required for an IPAA, and this in turn reduces the intra-operative blood loss and reduces the postoperative complications such as pelvic infections and adhesions. An IPAA reconstruction can occur in one, two, modified two or three step surgery. In Sweden the most common methods includes a temporary protective loop-ileostomy, that must later be reversed. ${ }^{(113,148)}$ In the first study, we detected that reconstruction with an IRA was performed at the same session of the subtotal colectomy in $71.6 \%$ of patients compared to $40.8 \%$ of IPAA patients.

Subtotal colectomy in UC patients does not, itself, seem to impair the fecundability and fertility in women. ${ }^{(149)}$ The following reconstruction with an IRA may help preserve future fecundability and fertility both for men and women because it does not entail a pelvic dissection. ${ }^{(6,112,149-156)}$ One of the disadvantages with IPAA is the pelvic dissection required with possible intraoperative injury to pelvic nerves and the later development of postoperative pelvic adhesions. Which in turn can cause impairment of fertility and fecundability. Male UC patients reconstructed with an IPAA suffer from sexual disturbances (e.g. sexual dysfunction and retrograde evacuation) due to damage to parasympathetic and sympathetic nerves during 
surgery. ${ }^{(157,158)}$ However, these sexual disturbances may also be due to other factors such as post-operative anatomical alterations, fibrosis, or psychological factors. ${ }^{(159)}$ Reports of sexual dysfunction ranges from as low as $3 \%$ up to $27 \% .^{(160)}$ There is today no knowledge if UC itself, or IPAA, changes the fertility in male patients.

Female patients as well suffer from sexual and fecundability problems after an IPAA. A recent study reported the cumulative incidence at 12, 24 and 60 months of successful pregnancy in females after an IPAA to be $18 \%, 27 \%$ and $36 \%$, while it was $78 \%, 85 \%$ and $90 \%$ in UC female patients before colectomy. ${ }^{(149)}$ Recently, small studies reported increased fecundity of UC female patients after laparoscopic reconstruction of IPAA compared to conventional IPAA, and less postoperative complications as well. ${ }^{(89,90)}$ Regarding childbirth, some authors recommend caesarean section for pregnant UC females in order to avoid the risk of sphincter injury that occurs in vaginal delivery, that can result in incontinence and significant deterioration of the functional results of IPAA. A study from North America reported that $38 \%$ to $78 \%$ of females with an IPAA, undergo a caesarean section compared to $22 \%$ vaginal delivery. They recommend also caesarean section also for patients with multiple abdominal incisions. ${ }^{(161)}$ On the other hand, another study reported that $56 \%$ of their patients had a vaginally delivery after IPAA with lack of significant impact on the long-term pouch function compared to women who had a caesarean section. However, the pouch related complications in these patients with IPAA increased after vaginal delivery. ${ }^{(162)}$ Another metaanalysis reported that pouch function returned into normal six months after vaginal delivery, and therefore concluded it to be safe. ${ }^{(163)}$

There are no studies in the literature describing how an IRA could impact childbirth in UC. However, in familial adenomatous polyposis (FAP) IRA has been shown not to impair fertility while an IPAA in FAP reduces fertility to 54\% ${ }^{(164)}$ Hypothetically, IRA should not complicate vaginal delivery since no pelvic dissection was performed. However, IRA patients 
may need a secondary IPAA later in life and future studies are required to compare how do pregnancy and different modes of delivery affect the reservoir function for both IRA and IPAA patients. In conclusion, further prospectively reported study is required to compare the short as well as the long-term outcomes of caesarean section and vaginal delivery on the function of IPAA and IRA.

Despite all the facts mentioned before, IPAA is still the preferred surgical reconstruction for UC patients in most countries. From this thesis and other studies, we can conclude it is the safest surgical reconstruction after subtotal colectomy in UC patients ${ }^{(5,29)}$. However, pouchitis is still an issue that a considerable number of patients suffers from. Studies reported up to $20.5 \%$ refractory pouchitis ${ }^{(165)}$ and $10-15 \%$ treatment failure to control severe pouchitis ${ }^{(166)}$ with a risk of subsequent pouch failure and even excision. In such case, patients will lose continence and will end up with a permanent ileostomy in most instances. Studies reported that IPAA failure occur early after reconstruction, ranging from $4 \%$ at five years and up to $14.6 \%$ in the first three years after ${ }^{(146,167)}$. Especially among the young, an interim solution with an IRA might have been of value. Apart from postponing pelvic surgery, IRA adds valuable time without a permanent stoma, but at the cost of an extra surgical procedure. IRA can also be a safe permanent reconstruction for elderly patients, if they are aware of the need for a topical therapy (e.g. high dose mesalamine) and annual follow up with flexible endoscopy and multiple biopsies. ${ }^{(6,11,15,25)}$

We have mentioned earlier that IRA is a safe surgical reconstruction after subtotal colectomy for selected UC patients. Thus, there is also a group of patients who should not be offered an IRA;

The risk for UC patients with a concomitant PSC diagnosis to develop rectal cancer in the rectal mucosa of their IRA was 6 times higher than in UC without a PSC. ${ }^{(125)}$ Moreover, the rectum was the second most common primary CRC location (after caecum/ascending and 
transverse) in UC/PSC+ patients regardless of a previous subtotal colectomy or not. ${ }^{(59,125)}$ Such a risk of rectal cancer was not detected for UC/PSC+ patients with an interrupted bowel stream who kept a functioning stoma and an intact, but disconnected rectum in place. Additionally, a recent animal study reported that faecal transplant from PSC-UC patients could induce PSC-UC colitis. However, after 90 days of follow up , no hepatic injury was detected. In order to induce liver inflammation, an IV injection of 3 types of bacteria was necessary. ${ }^{(168,169)}$ Moreover, other studies reported that PSC recurred in some UC patients after liver transplantation ${ }^{(170,171)}$, especially those with an intact colon before transplantation. ${ }^{(172,173)}$ Altogether this speaks towards the theory that PSC-UC colitis require an intact bowel stream to occur while and the hepatic injury occurs through enterohepatic circulation.

Interestingly, when we investigated the effect of a concomitant PSC on IBD patients without a previous subtotal colectomy we detected more proximal cancers (caecum/ascending colon) and transverse colon than in the general population. A similar finding was previously described as a characteristic finding for IBD/PSC+ patients. ${ }^{(63,174)}$ This supports our theory about an injurious agent that travel across the bowel in patients with an intact colon, resulting in the caecum/ascending and transverse receiving the highest concentration of this injurious agent/agents. This logically leads to another question - what is that injurious agent/agents?

Previous research suggested that proximal colon either receives a high concentration of secondary bile acids ${ }^{(59)}$ or that there is a different, and also more concentrated, microbiota detected in the right side of the colon of IBD/PSC+ patients ${ }^{(175)}$, at least in comparison with healthy controls. ${ }^{(176)}$ The microbiota, through the entero-hepatic circulation, translocate to the healthy transplanted liver and re-infect it. ${ }^{(177)}$ Consequently, this may increase the risk of recurrent PSC after liver transplantation. ${ }^{(178,179)}$ Interaction between both factors can cause a more aggressive disease behaviour in PSC+ patients. ${ }^{(57)}$ Another study reported a four-fold 
increased risk of sub-clinical inflammation, both endoscopically and histologically, in the mucosa of the right side of the colon (caecum, ascending and transverse) among PSC+ UC patients in clinical remission compared to UC patients without PSC. The severity of inflammation was higher on the right side of the colon compared to the rectum of the same patients. ${ }^{(58)}$ The potential mechanisms behind this and the tumour distribution are yet unclear. The next question arising here is whether UC in combination with PSC+ increases the CRC or is it the PSC+ per se? Looking at this cohort of patients with PSC but without concurrent IBD is more or less impossible using NPR. This is due to the limitation that PSC does not have a specific code as it is grouped together with any kind of cholangitis and PSC is generally considered only when there is a combination of codes for IBD and cholangitis. ${ }^{(180)}$ To answer this question as good as possible with our material, we looked into PSC as an independent risk factor for CRC. In the last study, we concluded that young IBD/PSC+ patients (diagnosed at/before 20 years of age) had an increased lifetime risk of CRC compared to IBD/PSC- as well as controls of the same age. Another conclusion was that UC patients and IBD-Mix patients had the highest risk to develop CRC in case of PSC+. PSC+ patients also had an increased risk to develop synchronous CRC but had a lower risk to develop metachronous cancers, compared to both PSC- and controls. A possible explanation for such a low incidence of metachronous cancers is that surgeons could tend to perform more extensive resections when a PSC diagnosis is added.

The second group of patients who should avoid an IRA is IBD patients with or without a concomitant PSC but with a previous colonic dysplasia or cancer. In paper IV, we detected that PSC- developed more metachronous cancers than PSC+ patients after subtotal colectomy, mostly in the rectum. Surprisingly, as many as $44(53.7 \%)$ patients having had a segmental colonic resection for their primary CRC developed metachronous cancers (17 UC, $16 \mathrm{CD}, 3$ IC, and 8 IBD-Mix) Of these seven patients developed a metachronous rectal cancer after 
segmental colectomy (4 UC, 2 CD, and one IBD-Mix). In the first study of this thesis, UC patients who underwent a subtotal colectomy for dysplasia/cancer, had a four-fold increased risk of developing rectal cancer in their diverted rectum compared to those who underwent subtotal colectomy for other reasons. Similarly, a previous study concluded that despite the reported increased risk of metachronous cancers in IBD patients with a previous $\mathrm{CRC}$, more than $75 \%$ of them received segmental colectomy. ${ }^{(47)}$ These findings lead to an important conclusion in IBD patients, no colon or rectum should be left behind in case of a cancer diagnosis unless strong contraindications against this are present.

The third group of patients who should not undergo an IRA is UC patients with poor general condition who are unfit for further surgical reconstruction. After the subtotal colectomy with ileostomy, further surgical intervention depends on the cause of subtotal colectomy as well as the pathology report of the resected colon. If dysplasia/cancer were the cause of colectomy or were detected on the specimen, patients should be advised to undergo a completion proctectomy as soon as their general condition permits to avoid the risk of rectal cancer in their rectal remnant. ${ }^{(7)}$

\section{Strengths \& Limitations}

There are some strengths and limitation for our studies. For three out of four studies, we have included a large sample size of prospectively recorded, unselected, data from a national cohort and a long follow up period. We have obtained our data from the National Patient Register (NPR), thus we could avoid a possible selection bias of cancer and PSC+ patients recruited from tertiary care centers (papers I and IV). However, including data from the NPR carries the possible risk of miss-coding in some instances. Whenever possible, we scrutinized suspicious data manually and they were very few, but the large number of patients included can compensate for the minor miss-coding. A recent review of national registers estimated the 
validity of the NPR up to $85-95 \%{ }^{(117)}$ with a long follow up period make the register suitable for large-scale population-based research. In a recent validation of the NPR the positive predictive value of an IBD diagnosis in the NPR was 93\% (95\% CI: 87-97) if individuals with $\geq 2$ codes of IBD were included (hospitalizations or non-primary care outpatient visits). ${ }^{(17)}$ Linkage to the Swedish Cancer Registry, which is mandatory for both clinicians and pathologists to report to, increases the validity of the cancer diagnoses. ${ }^{(32)}$

An additional limitation of cohorts obtained from NPR (papers I, II and IV) is that the lack of some personal and environmental factors, such as diet, smoking, family history (IBD, PSC or CRC), the length of the rectal segment of the IRA (paper I), the function of primary or secondary IPAA and why the restorative procedure failed (paper II), as well as the location and extent of colitis and detailed data about the tumor staging (paper IV). Consequently, RC in IRA patients may be overestimated because some patients might have had a sigmoid cancer rather than a true $\mathrm{RC}$, as the comparison is made only with $\mathrm{RC}$ in the general population (paper I). Further, neither the cause of failure of primary or secondary IPAA was detected (paper II), nor the effect of severity of IBD on the risk of CRC as well survival of patients after CRC were investigated (paper IV).

Regarding (papers I and IV), long-term follow up enabled the detection of CRC occurring in a relatively small patient population with PSC. However, there were some limitations, as the studied exposure in our study PSC diagnosis had no specific ICD code. To overcome this problem, similar to previous studies on PSC, we have used the combination of a cholangitis code together with an IBD diagnosis ${ }^{(180,181)}$. However, it would be much easier for future research if the next version of ICD contained a specific code for PSC. 


\section{Paper I}

An overestimation of the relative risk of cancer in IRA may have occurred. A previous study from Sweden found the anastomoses after IRA to be at the level of $26 \mathrm{~cm}$ above the anal

verge in average. ${ }^{(27)}$ As a result, some of the assumed IRA are in fact ileo-sigmoidal anastomoses and some sigmoidal cancers may have been misclassified as rectal cancers. The same applies to patients with diverted rectum as more than $15 \mathrm{~cm}$ of the distal bowel is commonly left at colectomy.

Moreover, there is a possibility that asymptomatic cancers were present at colectomy and remained undetected until months or even years after the colectomy. However, there was only a small risk of rectal cancer development during the first 10 years after IRA (Figure 10), and most patients with the rectum left in situ were diagnosed with RC more than five years after the subtotal colectomy (figure 11). This is in line with previous reports from our own and other centers. ${ }^{(6,69,182,183)}$

\section{Paper II}

The comparison between primary and secondary IPAA may be described as under-powered. This could be true but adding four more years to the follow up time did not increase the study power as well. It requires 46 secondary IPAA failures to occur in order to detect a statistically significant difference. If we could not detect any statistically significant difference from this national cohort of patients with such a long follow up period, one could question if there is a clinically significant difference even if a difference existed in an even larger cohort.

\section{Paper III}

Patients were consecutively recruited without matching for age or sex but there were no significant differences between the two groups. Additionally, there were no significant 
differences regarding the occurrence of inflammation, either macro- and microscopically, between the IRA and IPAA groups.

The sample size was quite small in both groups and there was a long-time interval (up to 12.5 years) between the time at reconstruction with either an IRA or an IPAA and the time of participation in the study. This may affect the function of the reconstruction because it may get impaired after a longer follow up. ${ }^{(184)}$ Firstly, the time of follow up was similar in both groups. Secondly, we compared the results of the self-reported QoL and ano-rectal function questionnaires, to the results of endoscopic evaluations and pathology reports of the biopsies obtained from the same UC patients. There were only three weeks interval between answering the questionnaires and going through endoscopic evaluation. This could point out the actual magnitude of the patients' problems regarding their QoL.

Some patients suffered from pouchitis when they participated in the study, leading to worse QoL perception. One explanation to that may be that patients who suffer from more symptoms are more prone to accept being included in the study.

To increase the strength of this thesis, whenever possible we compared to age, sex and year matched controls from the general population (paper I) or assigned five matched non-IBD controls according to age, sex, time of, as well as residence at time of IBD diagnosis of all patient diagnosed with IBD (paper IV).

The strength of this thesis is that it investigated most of the alleged criticism against IRA in ulcerative colitis patients. To the author's knowledge, this is the first study to compare the risk of rectal cancer in UC patients after colectomy and permanent ileostomy, diverted rectum or reconstruction with either an IRA or IPAA and trying to identify risk factors for each surgical option. Moreover, it is the first study to evaluate the risk of CRC in IBD with and without a concomitant PSC diagnosis compared to matched controls obtained from all levels of health 
care. It is also the first to highlight the increased risk of CRC in the IBD-Mix patients with and without PSC diagnosis. Additionally, it is the first large scale study to investigate the effect of PSC on the location of CRC after a long follow up time obtained all levels of health care (not only tertiary care centers) and the first to report the risk of synchronous/metachronous cancer in IBD patients after segmental colonic resection.

When it comes to functional results this is the first study to compare the QoL and anorectal function in UC patients reconstructed with an IRA versus an IPAA using validated questionnaires. To our knowledge, it is the only study that tested the association between the results of the self-reported QoL and anorectal function to the results of endoscopic and microscopic evaluations, regarding inflammatory activity. Finally, this is the first study in Sweden to investigate the survival of primary versus secondary IPAA created after a failed IRA in a national based data of UC patients over a long follow up. 


\section{Conclusions}

IRA is a safe procedure in selected UC patients with an evidence of good postoperative anorectal function. The cumulative risk for cancer is $1.6 \%$ and $5.6 \%$ at 10 and 20 years. It can be offered as an interim surgery in selected young UC patients willing to maintain fertility and a permanent surgery in older patients. However, these patients should be aware of the need for an annual postoperative endoscopic evaluation with biopsies as well as the need to use of local anti-inflammatory preparations. In case of IRA failure, a secondary IPAA could be reconstructed with no increased risk of failure.

However, IRA should not be offered for UC patients with an associated PSC diagnosis due to the increased risk to develop rectal cancer in their rectal mucosa. In such case, IPAA is probably the treatment of choice. 


\section{Future studies}

In order to thoroughly evaluate a possible superiority of IRA in selected UC patients, several studies are required.

A prospective study of UC patients operated with either IRA, IPAA or Kock pouch regarding:

1. The QoL and reservoir function for each reconstruction early and late postoperative.

2. In case of reconstruction failure, evaluation of post failure QoL.

3. Endoscopic evaluation with biopsies to check for levels of inflammation, both macroand microscopically, and to evaluate the response of inflammation in the reservoir to local anti-inflammatory preparations.

4. Economic evaluation of each reconstruction alternative.

More research is needed to understand the underlying pathological mechanism in IBD patients with mixed IBD diagnoses that causes such unresponsiveness to medications and the increased cancer risk that seems to be present.

More research on the use of specific anti-microbiota treatment on the disease behaviour of IBD/PSC + after the reported poor surgical outcomes and inconclusive evidence regarding ursodeoxycholic acid treatment. 


\section{Clinical applications of the thesis}

1. PSC patients should not be offered an IRA after colectomy. They should either get a permanent ileostomy with a diverted rectum (DR) or undergo a completion proctectomy and an IPAA.

2. IBD patients who are diagnosed with CRC should not get a segmental/subtotal colectomy, because more than one of two patients risk developing a synchronous or metachronous cancers in their remaining colon and rectum. The same may be true for IBD patients with severe dysplasia but needs further investigation.

3. IRA is a safe surgical option in selected patients. Although the relative risk for rectal cancer after IRA is high with a RR 8.9 , the absolute risk is $1.8 \%$ after a mean follow up of 8.6 years and the cumulative risk is $1.6 \%$ and $5.6 \%$ at 10 and 20 years respectively. In young IBD patients without an associated PSC diagnosis who wants to have children, as well as older patients who are not willing to undergo a major operation like IPAA, an IRA may be a valid option, but annual endoscopic surveillance and biopsies is recommended. This procedure is relatively easy and well tolerated. To decrease the risk of developing recurrent proctitis, topical anti-inflammatory therapy is recommended. This therapy is well tolerated and seem to be not only effective to treat inflammation but also protective against cancer.

4. Ano-rectal function in IRA is markedly better than IPAA in ulcerative colitis patients while QoL is no different compared with IPAA in ulcerative colitis patients.

5. In case of IRA failure, it is possible for the ulcerative colitis patient to keep continence if he/she get a secondary IPAA or a continent ileostomy. 


\section{Populärvetenskaplig sammanfattning}

\section{Cancer och återställande kirurgi vid inflammatorisk tarmsjukdom}

Ulcerös kolit (UC) är en kronisk inflammatorisk tarmsjukdom av okänd orsak. En tredjedel av patienter med UC behöver genomgå borttagande av tjocktarmen med tunntarmsstomi på grund av akut inflammation, otillräcklig effekt av medicinisk behandling eller utveckling av cellförändringar eller cancer i tjocktarmen. Nästa steg är beroende på patients allmäntillstånd och önskemål. Efter värdering och råd från kirurger får patienten bestämma att återställa sin tarmkontinuitet eller inte. Vissa patienter med dåligt allmäntillstånd avråds från ytterligare operationer och att behålla sin stomi med den urkopplade ändtarmen kvar. Det finns väldigt lite kunskap om cancerrisken på sikt i den patientgruppen. Andra patienter föredrar att bli av med sin stomi och samtycker därför till ytterligare kirurgi för att återställa tarmens kontinuitet. Det finns två typ huvudsakliga former av återställande operationer, ileo-rektal anastomos (IRA) eller bäckenreservoar (BR).

Precis som namnet anger innebär en operation med IRA att sista delen av patientens tunntarm kopplas till patientens kvarvarande ändtarm. Operationen är ganska enkelt då ingen bäckendissektion behövs och följaktligen mindre blödning och kortare operationstid. Dock föredrar många kirurger att inte föreslå IRA på grund av en ökad cancerrisk i den kvarvarande ändtarmsslemhinnan. Det finns dock väldigt lite forskning om hur stor denna risk verkligen är. Det finns även en risk för inflammation i ändtarmen vilken fordrar medicinsk behandling och kan försämra livskvaliteten. Vad som händer för patienter där en IRA inte fungerar och ändtarmen behöver opereras bort är ytterligare en fråga utan svar i nuläget.

BR är den förhärskande operationsmetoden för patienter med UC som fått sin tjocktarm bortopererad i övriga världen, med undantag av Sverige. Rekonstruktion med BR innebär ofta 
operationer i flera steg. Första steget är kompletterande operation med borttagande av ändtarmen, med viss associerad risk för blödning och skador på bäckennerver. Vid samma tillfälle konstrueras reservoaren, vilket i sig kan vara svårt, som kopplas till analkanalen. Ofta görs en tillfällig avlastande stomi vid detta tillfälle för att skydda reservoarkonstruktionen. Sista steget är nedläggning av den avlastande tunntarmsstomin. Vid denna typ av rekonstruktion finns det en ökad risk av kirurgiska komplikationer, som till exempel bäckeninfektion, vilka senare kan påverka både patientens tarmfunktion och förmåga att få barn.

Det övergripande syftet med denna avhandling är att undersöka hur IRA fungerar som alternativ till en rekonstruktion med BR hos patienter med UC som fått sin tjocktarm bortopererad.

Uppgifter om alla patienter som vårdats för UC mellan 1964-2014 erhölls från Patientregistret. Inledningsvis studerade vi cancerrisken hos de UC-patienter som blivit av med sin tjocktarm och sedan behållit sin stomi men med en kvarvarande urkopplad ändtarm eller som rekonstruerats med IRA eller BR. Risken att utveckla rektalcancer vid IRA var $1.8 \%$ efter en uppföljning på i median av 8.6 år. Dock var en samtidig diagnos av gallgångssjukdomen primär skleroserande kolangit (PSC) associerat med en sex gånger ökad cancerrisk. Patienter som fått tjocktarmen borttagen pga cellförändringar eller cancer hade en tre gånger ökad cancerrisk i ändtarmen jämfört med befolkningen i övrigt. Hos patienter med BR var risken att utveckla cancerrisken mycket lägre än hos övriga befolkningen och endast en patient av 1796 utvecklade ändtarmscancer.

Den efterföljande studien undersökte den tarmfunktionen och livskvaliteten hos UC-patienter som rekonstruerats med IRA i jämförelse med de som rekonstruerats med BR. Därutöver studerades förekomst av endoskopisk och mikroskopisk inflammation i reservoar och ändtarm samt om detta påverkade funktionen eller livskvaliteten. Tarmfunktionen var bättre hos de 
med IRA jämfört med hos dem med BR, med undantag av trängningar till brådskande tarmtömning. Dessutom fanns smärre skillnader i livskvalitet men inga skillnader i endoskopisk eller mikroskopisk inflammation mellan grupperna. Patienter med BR som uppvisade tecken på inflammation vid endoskopi hade sämre tarmfunktion.

Den tredje studien studerade vad är det som händer med patienterna efter att en IRA behövt tas bort. De som opererats med en BR efter att ha först haft en IRA jämfördes med dem som direkt rekonstruerades med BR och vi kunde inte påvisa någon skillnad i hur stor andel av patienterna som fick sin bäckenreservoar urkopplad eller borttagen eller efter hur lång tid. Däremot kunde inte studiemetoden ge information om tarmfunktion eller livskvalitet.

Den avslutande studien undersökte PSC som riskfaktor till cancer hos patienter med IBD. Patienter med UC och IBD-U (där man inte med säkerhet vet om det rör sig om UC eller Crohn's sjukdom) och en samtidig PSC diagnos uppvisade den största risken att utveckla en tjock- eller ändtarmscancer. Dessutom har IBD-patienter med PSC en ökad risk att utveckla synkrona (mer än en tumör vid diagnostillfället) tjock-eller ändtarmscancrar. IBD-patienter utan förekomst av PSC hade den högsta risken att utveckla metakrona cancrar (en ny cancer senare i förloppet), mest troligt kopplat till att de mer sällan genomgick borttagande av hela tjocktarmen i jämförelse med de patienter som hade en samtidig förekomst av PSC.

Sammanfattningsvis kan IRA ses som ett säkert val för UC patienter som behövt operera bort sin tjocktarm, förutom hos dem med en samtidig PSC diagnos eller som haft tidigare uppvisat cellförändringar eller tidigare haft en cancer i tjock- eller ändtarmen. I dessa fall bör en BR ses som den rekommenderade rekonstruktionsmetoden. UC-patienter med ändtarmen kvar efter att tjocktarmen opererats bort bör behandlas med lokal anti-inflammatorisk behandling. Denna behandling är väl tolererad och tros kunna minska risken för utveckling av ändtarmscancer. Därutöver bör patienter som rekonstruerats med IRA vara medvetna om 
rekommendationen på årliga endoskopiska kontroller med cellprover för tidig diagnos av cellförändringar eller cancer, tillstånd som medför att ändtarmen bör opereras bort. IBD patienter, oavsett en samtidig PSC eller ej, men som fått tjocktarmen avlägsnad på grund av cellförändringar eller cancer i tjock- eller ändtarm bör genomgå borttagande av resterande tjock- och ändtarm på grund av den höga risken att utveckla nya cancertumörer i tjock- eller ändtarm. 


\section{Acknowledgments}

First above all, I would like to thank God for guiding me all over my life and providing me with all the privileges I have: My beloved family, my friends, my colleagues, both in Sweden and in Egypt as well as my supervisors. I would like to thank anyone who have ever taught me anything, anyone who supported me and even anyone who did not support me! They have all helped, motivated, and challenged me to further develop my life and career. Hereby I choose not to write names of people to thank because the list is very, very long. It starts from my parents and my brother all the way through my life including friends, preschool/school/university teachers as well as my colleagues, the juniors as well as the seniors. I would like to thank my friends, my supervisors and colleagues who made it delightful to live and work in Sweden. To my beloved husband and wonderful daughter Noor, you bring colours to my life and turn it into a wonderful adventure! Thank you! 


\section{References}

1. Borjesson L, Lundstam U, Oresland T, Brevinge H, Hulten L. The place for colectomy and ileorectal anastomosis: a valid surgical option for ulcerative colitis? Tech Coloproctol. 2006;10(3):237-41; discussion 41.

2. Tekkis PP, Purkayastha S, Lanitis S, Athanasiou T, Heriot AG, Orchard TR, et al. A comparison of segmental vs subtotal/total colectomy for colonic Crohn's disease: a metaanalysis. Colorectal disease : the official journal of the Association of Coloproctology of Great Britain and Ireland. 2006;8(2):82-90.

3. da Luz Moreira A, Kiran RP, Lavery I. Clinical outcomes of ileorectal anastomosis for ulcerative colitis. Br J Surg. 2010;97(1):65-9.

4. Duclos J, Lefevre JH, Lefrancois M, Lupinacci R, Shields C, Chafai N, et al. Immediate outcome, long-term function and quality of life after extended colectomy with ileorectal or ileosigmoid anastomosis. Colorectal disease : the official journal of the Association of Coloproctology of Great Britain and Ireland. 2014;16(8):O288-96.

5. Carter MJ, Lobo AJ, Travis SPL. Guidelines for the management of inflammatory bowel disease in adults. Gut. 2004;53(suppl 5):v1-v16.

6. Andersson P, Norblad R, Soderholm JD, Myrelid P. Ileorectal anastomosis in comparison with ileal pouch anal anastomosis in reconstructive surgery for ulcerative colitis--a single institution experience. J Crohns Colitis. 2014;8(7):582-9.

7. Juviler A, Hyman N. Ulcerative colitis: the fate of the retained rectum. Clin Colon Rectal Surg. 2004;17(1):29-34.

8. Eaden JA, Abrams KR, Mayberry JF. The risk of colorectal cancer in ulcerative colitis: a meta-analysis. Gut. 2001;48(4):526-35. 
9. Boonstra K, Weersma RK, van Erpecum KJ, Rauws EA, Spanier BW, Poen AC, et al. Population-based epidemiology, malignancy risk, and outcome of primary sclerosing cholangitis. Hepatology. 2013;58(6):2045-55.

10. Prefontaine E, Sutherland LR, Macdonald JK, Cepoiu M. Azathioprine or 6mercaptopurine for maintenance of remission in Crohn's disease. Cochrane Database Syst Rev. 2009(1):CD000067.

11. Loftus EV, Jr., Harewood GC, Loftus CG, Tremaine WJ, Harmsen WS, Zinsmeister AR, et al. PSC-IBD: a unique form of inflammatory bowel disease associated with primary sclerosing cholangitis. Gut. 2005;54(1):91-6.

12. Ananthakrishnan AN, Cagan A, Gainer VS, Cheng SC, Cai T, Szolovits P, et al. Mortality and extraintestinal cancers in patients with primary sclerosing cholangitis and inflammatory bowel disease. J Crohns Colitis. 2014;8(9):956-63.

13. Wang R, Leong RW. Primary sclerosing cholangitis as an independent risk factor for colorectal cancer in the context of inflammatory bowel disease: a review of the literature. World journal of gastroenterology. 2014;20(27):8783-9.

14. Oresland T, Bemelman WA, Sampietro GM, Spinelli A, Windsor A, Ferrante M, et al. European evidence based consensus on surgery for ulcerative colitis. J Crohns Colitis. $2015 ; 9(1): 4-25$.

15. Börjesson BL, Lindholm E, Block M, Boberg KM, Jørgensen KK, Vatn MH, et al. Colectomy for patients with ulcerative colitis and primary sclerosing cholangitis - What next? Journal of Crohn's and Colitis. 2014;8(5):421-30.

16. Kartheuser AH, Dozois RR, LaRusso NF, Wiesner RH, Ilstrup DM, Schleck CD. Comparison of surgical treatment of ulcerative colitis associated with primary sclerosing cholangitis: ileal pouch-anal anastomosis versus Brooke ileostomy. Mayo Clin Proc. 1996;71(8):748-56. 
17. Poritz LS, Koltun WA. Surgical management of ulcerative colitis in the presence of primary sclerosing cholangitis. Dis Colon Rectum. 2003;46(2):173-8.

18. Pavlides M, Cleland J, Rahman M, Christian A, Doyle J, Gaunt R, et al. Outcomes after ileal pouch anal anastomosis in patients with primary sclerosing cholangitis. J Crohns Colitis. 2014;8(7):662-70.

19. Kartheuser AH, Dozois RR, Wiesner RH, LaRusso NF, Ilstrup DM, Schleck CD. Complications and risk factors after ileal pouch-anal anastomosis for ulcerative colitis associated with primary sclerosing cholangitis. Annals of surgery. 1993;217(4):314-20.

20. Block M, Jorgensen KK, Oresland T, Lindholm E, Grzyb K, Cvancarova M, et al. Colectomy for patients with ulcerative colitis and primary sclerosing cholangitis - what next? J Crohns Colitis. 2014;8(5):421-30.

21. Ng SC, Shi HY, Hamidi N, Underwood FE, Tang W, Benchimol EI, et al. Worldwide incidence and prevalence of inflammatory bowel disease in the 21 st century: a systematic review of population-based studies. The Lancet. 2017;390(10114):2769-78.

22. Abraham C, Cho JH. Inflammatory Bowel Disease. New England Journal of Medicine. 2009;361(21):2066-78.

23. Abegunde AT, Muhammad BH, Bhatti O, Ali T. Environmental risk factors for inflammatory bowel diseases: Evidence based literature review. World journal of gastroenterology. 2016;22(27):6296-317.

24. Yang H, Taylor KD, Rotter JI. Inflammatory Bowel Disease: I. Genetic Epidemiology. Molecular Genetics and Metabolism. 2001;74(1):1-21.

25. Heuschen UA, Hinz U, Allemeyer EH, Stern J, Lucas M, Autschbach F, et al. Backwash ileitis is strongly associated with colorectal carcinoma in ulcerative colitis. Gastroenterology. 2001;120(4):841-7. 
26. Solberg IC, Lygren I, Jahnsen J, Aadland E, Hoie O, Cvancarova M, et al. Clinical course during the first 10 years of ulcerative colitis: results from a population-based inception cohort (IBSEN Study). Scand J Gastroenterol. 2009;44(4):431-40.

27. Matsuoka K, Kobayashi T, Ueno F, Matsui T, Hirai F, Inoue N, et al. Evidence-based clinical practice guidelines for inflammatory bowel disease. Journal of Gastroenterology. 2018;53(3):305-53.

28. Kornbluth A, Sachar DB. Ulcerative colitis practice guidelines in adults: American College Of Gastroenterology, Practice Parameters Committee. Am J Gastroenterol. 2010;105(3):501-23; quiz 24.

29. Bernstein CN, Eliakim A, Fedail S, Fried M, Gearry R, Goh KL, et al. World Gastroenterology Organisation Global Guidelines Inflammatory Bowel Disease: Update August 2015. J Clin Gastroenterol. 2016;50(10):803-18.

30. Thoreson R, Cullen JJ. Pathophysiology of Inflammatory Bowel Disease: An Overview. Surgical Clinics of North America. 2007;87(3):575-85.

31. Panes J, Gomollon F, Taxonera C, Hinojosa J, Clofent J, Nos P. Crohn's disease: a review of current treatment with a focus on biologics. Drugs. 2007;67(17):2511-37.

32. Solberg IC, Vatn MH, Hoie O, Stray N, Sauar J, Jahnsen J, et al. Clinical course in Crohn's disease: results of a Norwegian population-based ten-year follow-up study. Clin Gastroenterol Hepatol. 2007;5(12):1430-8.

33. Thoreson R, Cullen JJ. Pathophysiology of inflammatory bowel disease: an overview. Surg Clin North Am. 2007;87(3):575-85.

34. Satsangi J, Silverberg MS, Vermeire S, Colombel JF. The Montreal classification of inflammatory bowel disease: controversies, consensus, and implications. Gut. 2006;55(6):749-53. 
35. Everhov ÅH, Sachs MC, Malmborg P, Nordenvall C, Myrelid P, Khalili H, et al. Changes in inflammatory bowel disease subtype during follow-up and over time in 44,302 patients AU - Everhov, Åsa H. Scandinavian Journal of Gastroenterology. 2019:1-9.

36. Bertha M, Chandradevan R, Somineni HK, Mondal K, Venkateswaran S, Sauer CG, et al. Evolution of Pediatric Inflammatory Bowel Disease Unclassified (IBD-U): Incorporated With Serological and Gene Expression Profiles. Inflammatory Bowel Diseases. 2018;24(10):228590.

37. Rutter M, Saunders B, Wilkinson K, Rumbles S, Schofield G, Kamm M, et al. Severity of inflammation is a risk factor for colorectal neoplasia in ulcerative colitis. Gastroenterology. 2004;126(2):451-9.

38. Rubin DT, Huo D, Kinnucan JA, Sedrak MS, McCullom NE, Bunnag AP, et al. Inflammation is an independent risk factor for colonic neoplasia in patients with ulcerative colitis: a case-control study. Clin Gastroenterol Hepatol. 2013;11(12):1601-8.e1-4.

39. van Hogezand RA, Eichhorn RF, Choudry A, Veenendaal RA, Lamers CB. Malignancies in inflammatory bowel disease: fact or fiction? Scand J Gastroenterol Suppl. 2002;236(236):48-53.

40. Egan L, D'Inca R, Jess T, Pellino G, Carbonnel F, Bokemeyer B, et al. Non-colorectal intestinal tract carcinomas in inflammatory bowel disease: results of the 3rd ECCO Pathogenesis Scientific Workshop (II). J Crohns Colitis. 2014;8(1):19-30.

41. Sebastian S, Hernandez V, Myrelid P, Kariv R, Tsianos E, Toruner M, et al. Colorectal cancer in inflammatory bowel disease: results of the 3rd ECCO pathogenesis scientific workshop (I). J Crohns Colitis. 2014;8(1):5-18.

42. Munkholm P. Review article: the incidence and prevalence of colorectal cancer in inflammatory bowel disease. Aliment Pharmacol Ther. 2003;18 Suppl 2(s2):1-5. 
43. Kim ER, Chang DK. Colorectal cancer in inflammatory bowel disease: the risk, pathogenesis, prevention and diagnosis. World journal of gastroenterology. 2014;20(29):9872-81.

44. East JE, Boyapati RK, Torres J, Parker CE, MacDonald JK, Chande N, et al. Controversies in Inflammatory Bowel Disease: Exploring Clinical Dilemmas Using Cochrane Reviews. Inflamm Bowel Dis. 2019;25(3):472-8.

45. Jess T, Simonsen J, Jorgensen KT, Pedersen BV, Nielsen NM, Frisch M. Decreasing risk of colorectal cancer in patients with inflammatory bowel disease over 30 years.

Gastroenterology. 2012;143(2):375-81 e1; quiz e13-4.

46. Dulai PS, Sandborn WJ, Gupta S. Colorectal Cancer and Dysplasia in Inflammatory Bowel Disease: A Review of Disease Epidemiology, Pathophysiology, and Management. Cancer Prevention Research. 2016;9(12):887-94.

47. Gearhart SL, Nathan H, Pawlik TM, Wick E, Efron J, Shore AD. Outcomes from IBDassociated and non-IBD-associated colorectal cancer: a Surveillance Epidemiology and End Results Medicare study. Dis Colon Rectum. 2012;55(3):270-7.

48. Van Der Kraak L, Gros P, Beauchemin N. Colitis-associated colon cancer: Is it in your genes? World journal of gastroenterology. 2015;21(41):11688-99.

49. Axelrad JE, Lichtiger S, Yajnik V. Inflammatory bowel disease and cancer: The role of inflammation, immunosuppression, and cancer treatment. World journal of gastroenterology. 2016;22(20):4794-801.

50. Stjärngrim J, Ekbom A, Hammar U, Hultcrantz R, Forsberg AM. Rates and characteristics of postcolonoscopy colorectal cancer in the Swedish IBD population: what are the differences from a non-IBD population? Gut. 2018:gutjnl-2018-316651.

51. Lindor KD, Kowdley KV, Harrison ME. ACG Clinical Guideline: Primary Sclerosing Cholangitis. Am J Gastroenterol. 2015;110(5):646-59; quiz 60. 
52. Andersen IM, Fosby B, Boberg KM, Clausen OPF, Jebsen P, Melum E, et al. Indications and Outcomes in Liver Transplantation in Patients With Primary Sclerosing Cholangitis in Norway. Transplantation direct. 2015;1(9):e39-e.

53. Karlsen TH, Folseraas T, Thorburn D, Vesterhus M. Primary sclerosing cholangitis \&\#x2013; a comprehensive review. Journal of Hepatology. 2017;67(6):1298-323.

54. Bambha K, Kim WR, Talwalkar J, Torgerson H, Benson JT, Therneau TM, et al. Incidence, clinical spectrum, and outcomes of primary sclerosing cholangitis in a United States community. Gastroenterology. 2003;125(5):1364-9.

55. Boonstra K, Beuers U, Ponsioen CY. Epidemiology of primary sclerosing cholangitis and primary biliary cirrhosis: a systematic review. J Hepatol. 2012;56(5):1181-8.

56. Sabino J, Vieira-Silva S, Machiels K, Gut J-M. Primary sclerosing cholangitis is characterised by intestinal dysbiosis independent from IBD. Gut. 2016.

57. Torres J, Palmela C, Brito H, Bao X, Ruiqi H, Moura-Santos P, et al. The gut microbiota, bile acids and their correlation in primary sclerosing cholangitis associated with inflammatory bowel disease. United European gastroenterology journal. 2018;6(1):112-22.

58. Cleveland NK, Rubin DT, Hart J, Weber CR, Meckel K, Tran AL, et al. Patients With Ulcerative Colitis and Primary Sclerosing Cholangitis Frequently Have Subclinical Inflammation in the Proximal Colon. Clinical Gastroenterology and Hepatology. 2018;16(1):68-74.

59. Chazouilleres O. Primary sclerosing cholangitis and bile acids. Clinics and research in hepatology and gastroenterology. 2012;36 Suppl 1:S21-5.

60. Claessen MM, Vleggaar FP, Tytgat KM, Siersema PD, van Buuren HR. High lifetime risk of cancer in primary sclerosing cholangitis. J Hepatol. 2009;50(1):158-64. 
61. Shetty K, Rybicki L, Brzezinski A, Carey WD, Lashner BA. The risk for cancer or dysplasia in ulcerative colitis patients with primary sclerosing cholangitis. Am J Gastroenterol. 1999;94(6):1643-9.

62. Torres J, Pineton de Chambrun G, Itzkowitz S, Sachar DB, Colombel JF. Review article: colorectal neoplasia in patients with primary sclerosing cholangitis and inflammatory bowel disease. Aliment Pharmacol Ther. 2011;34(5):497-508.

63. Claessen MM, Lutgens MW, van Buuren HR, Oldenburg B, Stokkers PC, van der Woude $\mathrm{CJ}$, et al. More right-sided IBD-associated colorectal cancer in patients with primary sclerosing cholangitis. Inflamm Bowel Dis. 2009;15(9):1331-6.

64. Ten Hove JR, Bogaerts JMK, Bak MTJ, Lacle MM, Meij V, Derikx L, et al. Malignant and Nonmalignant Complications of the Rectal Stump in Patients with Inflammatory Bowel Disease. Inflamm Bowel Dis. 2019;25(2):377-84.

65. Farmer RG, Easley KA, Rankin GB. Clinical patterns, natural history, and progression of ulcerative colitis. A long-term follow-up of 1116 patients. Dig Dis Sci. 1993;38(6):1137-46. 66. Andersson P, Soderholm JD. Surgery in ulcerative colitis: indication and timing. Dig Dis. 2009;27(3):335-40.

67. Landerholm K, Wood C, Bloemendaal A, Buchs N, George B, Guy R. The rectal remnant after total colectomy for colitis - intra-operative,post-operative and longer-term considerations. Scandinavian Journal of Gastroenterology. 2018;53(12):1443-52. 68. Aylett SO. Conservative surgery in the treatment of ulcerative colitis. Br Med J. 1953;2(4850):1348-51.

69. Baker WN, Glass RE, Ritchie JK, Aylett SO. Cancer of the rectum following colectomy and ileorectal anastomosis for ulcerative colitis. Br J Surg. 1978;65(12):862-8. 
70. Khubchandani IT, Stasik JJ, Jr., Nedwich A. Prospective surveillance by rectal biopsy following ileorectal anastomosis for inflammatory disease. Dis Colon Rectum. 1982;25(4):343-7.

71. Uzzan M, Cosnes J, Amiot A, Gornet JM, Seksik P, Cotte E, et al. Long-term Follow-up After Ileorectal Anastomosis for Ulcerative Colitis: A GETAID/GETAID Chirurgie Multicenter Retrospective Cohort of 343 Patients. Ann Surg. 2017;266(6):1029-34. 72. Nessar G, Wu JS. Evolution of continent ileostomy. World J Gastroenterol. 2012;18(27):3479-82.

73. Cranley B. The Kock reservoir ileostomy: a review of its development, problems and role in modern surgical practice. Br J Surg. 1983;70(2):94-9.

74. STEIN JP, LIESKOVSKY G, GINSBERG DA, BOCHNER BH, SKINNER DG. The T pouch: an orthotopic ileal neobladder incorporating a serosal lined ileal antireflux technique. The Journal of urology. 1998;159(6):1836-42.

75. Fazio VW, Tjandra JJ. Technique for nipple valve fixation to prevent valve slippage in continent ileostomy. Dis Colon Rectum. 1992;35(12):1177-9.

76. Hulten L, Svaninger G. Facts about the Kock continent ileostomy. Dis Colon Rectum. 1984;27(8):553-7.

77. Wu JS, Fazio VW. Continent ileostomy: evolution of design. Clinics in Colon and Rectal Surgery. 2002;15(03):231-44.

78. Kaiser AM, Stein JP, Beart RW, Jr. T-pouch: a new valve design for a continent ileostomy. Dis Colon Rectum. 2002;45(3):411-5.

79. Beck DE. Clinical aspects of continent ileostomies. Clinics in colon and rectal surgery. 2004;17(1):57-63.

80. Myrelid Pr, Block M. The Kock pouch. 2019. 
81. Um JW, M'Koma AE. Pouch-related dysplasia and adenocarcinoma following restorative proctocolectomy for ulcerative colitis. Tech Coloproctol. 2011;15(1):7-16.

82. Fazio VW, Kiran RP, Remzi FH, Coffey JC, Heneghan HM, Kirat HT, et al. Ileal pouch anal anastomosis: analysis of outcome and quality of life in 3707 patients. Ann Surg. 2013;257(4):679-85.

83. Parks AG, Nicholls RJ. Proctocolectomy without ileostomy for ulcerative colitis. British medical journal. 1978;2(6130):85-8.

84. Magro F, Gionchetti P, Eliakim R, Ardizzone S, Armuzzi A, Barreiro-de Acosta M, et al. Third European Evidence-based Consensus on Diagnosis and Management of Ulcerative Colitis. Part 1: Definitions, Diagnosis, Extra-intestinal Manifestations, Pregnancy, Cancer Surveillance, Surgery, and Ileo-anal Pouch Disorders. J Crohns Colitis. 2017;11(6):649-70. 85. Hahnloser D, Pemberton JH, Wolff BG, Larson DR, Crownhart BS, Dozois RR. Results at up to 20 years after ileal pouch-anal anastomosis for chronic ulcerative colitis. Br J Surg. 2007;94(3):333-40.

86. Fajardo AD, Dharmarajan S, George V, Hunt SR, Birnbaum EH, Fleshman JW, et al. Laparoscopic versus open 2-stage ileal pouch: laparoscopic approach allows for faster restoration of intestinal continuity. J Am Coll Surg. 2010;211(3):377-83.

87. Sofo L, Caprino P, Sacchetti F, Bossola M. Restorative proctocolectomy with ileal pouchanal anastomosis for ulcerative colitis: A narrative review. World J Gastrointest Surg. 2016;8(8):556-63.

88. Fleming FJ, Francone TD, Kim MJ, Gunzler D, Messing S, Monson JR. A laparoscopic approach does reduce short-term complications in patients undergoing ileal pouch-anal anastomosis. Dis Colon Rectum. 2011;54(2):176-82. 
89. Beyer-Berjot L, Maggiori L, Birnbaum D, Lefevre JH, Berdah S, Panis Y. A total laparoscopic approach reduces the infertility rate after ileal pouch-anal anastomosis: a 2center study. Ann Surg. 2013;258(2):275-82.

90. Bartels SA, D'Hoore A, Cuesta MA, Bensdorp AJ, Lucas C, Bemelman WA. Significantly increased pregnancy rates after laparoscopic restorative proctocolectomy: a cross-sectional study. Ann Surg. 2012;256(6):1045-8.

91. Weston-Petrides GK, Lovegrove RE, Tilney HS, Heriot AG, Nicholls RJ, Mortensen NJ, et al. Comparison of outcomes after restorative proctocolectomy with or without defunctioning ileostomy. Arch Surg. 2008;143(4):406-12.

92. Pandey S, Luther G, Umanskiy K, Malhotra G, Rubin MA, Hurst RD, et al. Minimally invasive pouch surgery for ulcerative colitis: is there a benefit in staging? Dis Colon Rectum. 2011;54(3):306-10.

93. Zittan E, Wong-Chong N, Ma GW, McLeod RS, Silverberg MS, Cohen Z. Modified Twostage Ileal Pouch-Anal Anastomosis Results in Lower Rate of Anastomotic Leak Compared with Traditional Two-stage Surgery for Ulcerative Colitis. J Crohns Colitis. 2016;10(7):76672.

94. Nicholls RJ, Chir M, Holt SDH, Lubowski DZ. Restorative proctocolectomy with ileal reservoir. Diseases of the Colon \& Rectum. 1989;32(4):323-6.

95. Hicks CW, Hodin RA, Bordeianou L. Possible overuse of 3-stage procedures for active ulcerative colitis. JAMA Surg. 2013;148(7):658-64.

96. Bikhchandani J, Polites SF, Wagie AE, Habermann EB, Cima RR. National trends of 3versus 2-stage restorative proctocolectomy for chronic ulcerative colitis. Dis Colon Rectum. 2015;58(2):199-204. 
97. Lovegrove RE, Constantinides VA, Heriot AG, Athanasiou T, Darzi A, Remzi FH, et al. A comparison of hand-sewn versus stapled ileal pouch anal anastomosis (IPAA) following proctocolectomy: a meta-analysis of 4183 patients. Annals of surgery. 2006;244(1):18-26. 98. Lovegrove RE, Constantinides VA, Heriot AG, Athanasiou T, Darzi A, Remzi FH, et al. A comparison of hand-sewn versus stapled ileal pouch anal anastomosis (IPAA) following proctocolectomy: a meta-analysis of 4183 patients. Ann Surg. 2006;244(1):18-26.

99. Kirat HT, Remzi FH, Kiran RP, Fazio VW. Comparison of outcomes after hand-sewn versus stapled ileal pouch-anal anastomosis in 3,109 patients. Surgery. 2009;146(4):723-9; discussion 9-30.

100. Lovegrove RE, Heriot AG, Constantinides V, Tilney HS, Darzi AW, Fazio VW, et al. Meta-analysis of short-term and long-term outcomes of J, W and S ileal reservoirs for restorative proctocolectomy. Colorectal disease : the official journal of the Association of Coloproctology of Great Britain and Ireland. 2007;9(4):310-20.

101. Rokke O, Iversen K, Olsen T, Ristesund SM, Eide GE, Turowski GE. Long-term followup with evaluation of the surgical and functional results of the ileal pouch reservoir in restorative proctocolectomy for ulcerative colitis. ISRN Gastroenterol. 2011;2011:625842. 102. McCormick PH, Guest GD, Clark AJ, Petersen D, Clark DA, Stevenson AR, et al. The ideal ileal-pouch design: a long-term randomized control trial of J- vs W-pouch construction. Dis Colon Rectum. 2012;55(12):1251-7.

103. Windsor A, D’Hoore A, de Buck van Overstraeten A, Spinelli A, Faerden AE, Dignass A, et al. European evidence based consensus on surgery for ulcerative colitis. Journal of Crohn's and Colitis. 2014;9(1):4-25.

104. Block M, Borjesson L, Lindholm E, Oresland T. Pouch design and long-term functional outcome after ileal pouch-anal anastomosis. Br J Surg. 2009;96(5):527-32. 
105. Sunde ML, Oresland T, Engebreth Faerden A. Correlation between pouch function and sexual function in patients with IPAA. Scand J Gastroenterol. 2016;51(3):295-303. 106. Watanabe K, Nagao M, Suzuki H, Karasawa H, Ohnuma S, Musha H, et al. The functional outcome and factors influencing the quality of life after ileal pouch anal anastomosis in patients with ulcerative colitis. Surg Today. 2018;48(4):455-61.

107. Sunde ML, Ricanek P, Oresland T, Jahnsen J, Naimy N, Faerden AE. Determinants of optimal bowel function in ileal pouch-anal anastomosis - physiological differences contributing to pouch function. Scand J Gastroenterol. 2018;53(1):8-14.

108. Rajaratnam SG, Eglinton TW, Hider P, Fearnhead NS. Impact of ileal pouch-anal anastomosis on female fertility: meta-analysis and systematic review. Int J Colorectal Dis. 2011;26(11):1365-74.

109. Baek SJ, Lightner AL, Boostrom SY, Mathis KL, Cima RR, Pemberton JH, et al. Functional Outcomes Following Laparoscopic Ileal Pouch-Anal Anastomosis in Patients with Chronic Ulcerative Colitis: Long-Term Follow-up of a Case-Matched Study. J Gastrointest Surg. 2017;21(8):1304-8.

110. Nordenvall C, Myrelid P, Ekbom A, Bottai M, Smedby KE, Olen O, et al. Probability, rate and timing of reconstructive surgery following colectomy for inflammatory bowel disease in Sweden: a population-based cohort study. Colorectal disease : the official journal of the Association of Coloproctology of Great Britain and Ireland. 2015;17(10):882-90.

111. Tonelli F, Di Martino C, Giudici F. Could Total Colectomy with Ileorectal Anastomosis Be an Alternative to Total Proctocolectomy with Ileal Pouch-Anal Anastomosis in Selected Ulcerative Colitis Patients? Gastroenterol Res Pract. 2016;2016:5832743.

112. Mortier PE, Gambiez L, Karoui M, Cortot A, Paris JC, Quandalle P, et al. Colectomy with ileorectal anastomosis preserves female fertility in ulcerative colitis. Gastroenterol Clin Biol. 2006;30(4):594-7. 
113. Myrelid P, Oresland T. A reappraisal of the ileo-rectal anastomosis in ulcerative colitis. J Crohns Colitis. 2015;9(6):433-8.

114. Tonelli F, Di Martino C, Giudici F. Could Total Colectomy with Ileorectal Anastomosis Be an Alternative to Total Proctocolectomy with Ileal Pouch-Anal Anastomosis in Selected Ulcerative Colitis Patients? Gastroenterology research and practice. 2016;2016:5832743-. 115. Björk J, Åkerbrant H, Iselius L, Svenberg T, Öresland T, Påhlman L, et al. Outcome of primary and secondary ileal pouch-anal anastomosis and ileorectal anastomosis in patients with familial adenomatous polyposis. Diseases of the Colon \& Rectum. 2001;44(7):984-92. 116. National Board of Health and Welfare's. National Board of Health and Welfare's, Cancer Register.

117. Jakobsson GL, Sternegard E, Olen O, Myrelid P, Ljung R, Strid H, et al. Validating inflammatory bowel disease (IBD) in the Swedish National Patient Register and the Swedish Quality Register for IBD (SWIBREG). Scand J Gastroenterol. 2017;52(2):216-21.

118. Barlow L, Westergren K, Holmberg L, Talback M. The completeness of the Swedish Cancer Register: a sample survey for year 1998. Acta Oncol. 2009;48(1):27-33.

119. Socialstyrelsen. The Swedish Cancer registry.

120. Socialstyrelsen. Dödsorsakregistret.

121. Johansson LA, Björkenstam C, Westerling R. Unexplained differences between hospital and mortality data indicated mistakes in death certification: an investigation of 1,094 deaths in Sweden during 1995. Journal of Clinical Epidemiology. 2009;62(11):1202-9.

122. Brooke HL, Talbäck M, Hörnblad J, Johansson LA, Ludvigsson JF, Druid H, et al. The Swedish cause of death register. European journal of epidemiology. 2017;32(9):765-73.

123. Socialstyrelsen. Standardised Incidence Ratios Rectal Cancer: Swedish National Board of Health and Welfare; [Available from:

http://www.socialstyrelsen.se/statistik/statistikdatabas/diagnoserislutenvard. 
124. Sullivan M, Karlsson J, Ware JE. The Swedish SF-36 Health Survey-I. Evaluation of data quality, scaling assumptions, reliability and construct validity across general populations in Sweden. Social Science \& Medicine. 1995;41(10):1349-58.

125. Abdalla M, Landerholm K, Andersson P, Andersson RE, Myrelid P. Risk of Rectal Cancer After Colectomy for Patients With Ulcerative Colitis: A National Cohort Study. Clin Gastroenterol Hepatol. 2017;15(7):1055-60 e2.

126. da Luz Moreira A, Lavery IC. Ileorectal anastomosis and proctocolectomy with end ileostomy for ulcerative colitis. Clin Colon Rectal Surg. 2010;23(4):269-73.

127. Everhov AH, Halfvarson J, Myrelid P, Sachs MC, Nordenvall C, Soderling J, et al. Incidence and Treatment of Patients Diagnosed With Inflammatory Bowel Diseases at 60 Years or Older in Sweden. Gastroenterology. 2018;154(3):518-28.e15.

128. Shah SC, Khalili H, Gower-Rousseau C, Olen O, Benchimol EI, Lynge E, et al. SexBased Differences in Incidence of Inflammatory Bowel Diseases-Pooled Analysis of Population-Based Studies From Western Countries. Gastroenterology. 2018;155(4):1079-89 e3.

129. Abdalla M, Landerholm K, Andersson P, Andersson RE, Myrelid P. Risk of Rectal Cancer After Colectomy for Patients With Ulcerative Colitis - a National Cohort Study. Clinical Gastroenterology and Hepatology.

130. Shuno Y, Hata K, Sunami E, Shinozaki M, Kawai K, Kojima T, et al. Is surveillance endoscopy necessary after colectomy in ulcerative colitis? ISRN Gastroenterol. 2011;2011:509251.

131. Mark-Christensen A, Erichsen R, Brandsborg S, Rosenberg J, Qvist N, ThorlaciusUssing O, et al. Long-term Risk of Cancer Following Ileal Pouch-anal Anastomosis for Ulcerative Colitis. J Crohns Colitis. 2018;12(1):57-62. 
132. Stocchi L, Pemberton JH. POUCH AND POUCHITIS. Gastroenterology Clinics of North America. 2001;30(1):223-41.

133. Zezos P, Saibil F. Inflammatory pouch disease: The spectrum of pouchitis. World journal of gastroenterology. 2015;21(29):8739-52.

134. Madiba TE, Bartolo DC. Pouchitis following restorative proctocolectomy for ulcerative colitis: incidence and therapeutic outcome. J R Coll Surg Edinb. 2001;46(6):334-7.

135. Ricciuto A, Kamath BM, Griffiths AM. The IBD and PSC Phenotypes of PSC-IBD. Curr Gastroenterol Rep. 2018;20(4):16.

136. Pinczowski D, Ekbom A, Baron J, Yuen J, Adami HO. Risk factors for colorectal cancer in patients with ulcerative colitis: a case-control study. Gastroenterology. 1994;107(1):11720.

137. Christophi GP, Rengarajan A, Ciorba MA. Rectal budesonide and mesalamine formulations in active ulcerative proctosigmoiditis: efficacy, tolerance, and treatment approach. Clin Exp Gastroenterol. 2016;9:125-30.

138. Leijonmarck CE, Lofberg R, Ost A, Hellers G. Long-term results of ileorectal anastomosis in ulcerative colitis in Stockholm County. Dis Colon Rectum. 1990;33(3):195200.

139. Melville DM, Ritchie JK, Nicholls RJ, Hawley PR. Surgery for ulcerative colitis in the era of the pouch: the St Mark's Hospital experience. Gut. 1994;35(8):1076-80.

140. Gionchetti P, Amadini C, Rizzello F, Venturi A, Campieri M. Review article: treatment of mild to moderate ulcerative colitis and pouchitis. Aliment Pharmacol Ther. 2002;16 Suppl 4:13-9.

141. Scoglio D, Ahmed Ali U, Fichera A. Surgical treatment of ulcerative colitis: ileorectal vs ileal pouch-anal anastomosis. World J Gastroenterol. 2014;20(37):13211-8. 
142. Oresland T, Fasth S, Nordgren S, Akervall S, Hulten L. Pouch size: the important functional determinant after restorative proctocolectomy. Br J Surg. 1990;77(3):265-9. 143. Nordenvall C, Olen O, Nilsson PJ, Ekbom A, Bottai M, Myrelid P. The Fate of Reconstructive Surgery Following Colectomy for Inflammatory Bowel Disease in Sweden: A Population-based Cohort Study. J Crohns Colitis. 2016;10(10):1165-71.

144. Shawki S, Belizon A, Person B, Weiss EG, Sands DR, Wexner SD. What are the outcomes of reoperative restorative proctocolectomy and ileal pouch-anal anastomosis surgery? Dis Colon Rectum. 2009;52(5):884-90.

145. Tekkis PP, Lovegrove RE, Tilney HS, Smith JJ, Sagar PM, Shorthouse AJ, et al. Longterm failure and function after restorative proctocolectomy - a multi-centre study of patients from the UK National Ileal Pouch Registry. Colorectal disease : the official journal of the Association of Coloproctology of Great Britain and Ireland. 2010;12(5):433-41.

146. Wasmuth HH, Trano G, Wibe A, Endreseth BH, Rydning A, Myrvold HE. Failed pelvic pouch substituted by continent ileostomy. Colorectal disease : the official journal of the Association of Coloproctology of Great Britain and Ireland. 2010;12(7 Online):e109-13. 147. Berndtsson IE, Lindholm E, Oresland T, Hulten L. Health-related quality of life and pouch function in continent ileostomy patients: a 30-year perspective. Dis Colon Rectum. 2004;47(12):2131-7.

148. Nordenvall C, Myrelid P, Ekbom A, Bottai M, Smedby KE, Olén O, et al. Probability, rate and timing of reconstructive surgery following colectomy for inflammatory bowel disease in Sweden: a population-based cohort study. Colorectal Disease. 2015;17(10):882-90.

149. Ording Olsen K, Juul S, Berndtsson I, Oresland T, Laurberg S. Ulcerative colitis: female fecundity before diagnosis, during disease, and after surgery compared with a population sample. Gastroenterology. 2002;122(1):15-9. 
150. Waljee A, Waljee J, Morris AM, Higgins PD. Threefold increased risk of infertility: a meta-analysis of infertility after ileal pouch anal anastomosis in ulcerative colitis. Gut. 2006;55(11):1575-80.

151. Shin T, Okada H. Infertility in men with inflammatory bowel disease. World J Gastrointest Pharmacol Ther. 2016;7(3):361-9.

152. Andrews L, Mireskandari S, Jessen J, Thewes B, Solomon M, Macrae F, et al. Impact of familial adenomatous polyposis on young adults: quality of life outcomes. Dis Colon Rectum. 2007;50(9):1306-15.

153. van Balkom KA, Beld MP, Visschers RG, van Gemert WG, Breukink SO. Long-term results after restorative proctocolectomy with ileal pouch-anal anastomosis at a young age. Dis Colon Rectum. 2012;55(9):939-47.

154. Ogilvie JW, Jr., Goetz L, Baxter NN, Park J, Minami S, Madoff RD. Female sexual dysfunction after ileal pouch-anal anastomosis. Br J Surg. 2008;95(7):887-92.

155. Larson DW, Davies MM, Dozois EJ, Cima RR, Piotrowicz K, Anderson K, et al. Sexual function, body image, and quality of life after laparoscopic and open ileal pouch-anal anastomosis. Dis Colon Rectum. 2008;51(4):392-6.

156. Olsen KO, Juul S, Bulow S, Jarvinen HJ, Bakka A, Bjork J, et al. Female fecundity before and after operation for familial adenomatous polyposis. Br J Surg. 2003;90(2):227-31. 157. Palomba S, Sereni G, Falbo A, Beltrami M, Lombardini S, Boni MC, et al. Inflammatory bowel diseases and human reproduction: a comprehensive evidence-based review. World J Gastroenterol. 2014;20(23):7123-36.

158. Feagins LA, Kane SV. Sexual and reproductive issues for men with inflammatory bowel disease. Am J Gastroenterol. 2009;104(3):768-73.

159. Slors FJ, van Zuijlen PP, van Dijk GJ. Sexual and bladder dysfunction after total mesorectal excision for benign diseases. Scand J Gastroenterol Suppl. 2000(232):48-51. 
160. Hueting WE, Gooszen HG, van Laarhoven CJ. Sexual function and continence after ileo pouch anal anastomosis: a comparison between a meta-analysis and a questionnaire survey. Int J Colorectal Dis. 2004;19(3):215-8.

161. Magro F, Gionchetti P, Eliakim R, Ardizzone S, Armuzzi A, Barreiro-de Acosta M, et al. Third European Evidence-based Consensus on Diagnosis and Management of Ulcerative Colitis. Part 1: Definitions, Diagnosis, Extra-intestinal Manifestations, Pregnancy, Cancer Surveillance, Surgery, and Ileo-anal Pouch Disorders. Journal of Crohn's and Colitis. 2017;11(6):649-70.

162. Hahnloser D, Pemberton JH, Wolff BG, Larson D, Harrington J, Farouk R, et al. Pregnancy and delivery before and after ileal pouch-anal anastomosis for inflammatory bowel disease: immediate and long-term consequences and outcomes. Dis Colon Rectum. 2004;47(7):1127-35.

163. Cornish JA, Tan E, Teare J, Teoh TG, Rai R, Darzi AW, et al. The effect of restorative proctocolectomy on sexual function, urinary function, fertility, pregnancy and delivery: a systematic review. Dis Colon Rectum. 2007;50(8):1128-38.

164. Olsen KØ, Juul S, Bülow S, Järvinen HJ, Bakka A, Björk J, et al. Female fecundity before and after operation for familial adenomatous polyposis. BJS. 2003;90(2):227-31. 165. Fazio VW, Ziv Y, Church JM, Oakley JR, Lavery IC, Milsom JW, et al. Ileal pouch-anal anastomoses complications and function in 1005 patients. Ann Surg. 1995;222(2):120-7. 166. Persborn M, Gerritsen J, Wallon C, Carlsson A, Akkermans LMA, Söderholm JD. The effects of probiotics on barrier function and mucosal pouch microbiota during maintenance treatment for severe pouchitis in patients with ulcerative colitis. Alimentary Pharmacology \& Therapeutics. 2013;38(7):772-83. 
167. Fazio VW, Tekkis PP, Remzi F, Lavery IC, Manilich E, Connor J, et al. Quantification of risk for pouch failure after ileal pouch anal anastomosis surgery. Annals of surgery. 2003;238(4):605-17.

168. Patel M, Watson AJM, Rushbrook S. A Mechanistic Insight Into The Role Of Gut Microbiota In The Pathogenesis Of Primary Sclerosing Cholangitis. Gastroenterology. 2019. 169. Nakamoto N, Sasaki N, Aoki R, Miyamoto K, Suda W, Teratani T, et al. Gut pathobionts underlie intestinal barrier dysfunction and liver T helper 17 cell immune response in primary sclerosing cholangitis. Nature Microbiology. 2019;4(3):492-503.

170. Cholongitas E, Shusang V, Papatheodoridis GV, Marelli L, Manousou P, Rolando N, et al. Risk factors for recurrence of primary sclerosing cholangitis after liver transplantation. Liver Transpl. 2008;14(2):138-43.

171. Ravikumar R, Tsochatzis E, Jose S, Allison M, Athale A, Creamer F, et al. Risk factors for recurrent primary sclerosing cholangitis after liver transplantation. Journal of Hepatology. 2015;63(5):1139-46.

172. Alabraba E, Nightingale P, Gunson B, Hubscher S, Olliff S, Mirza D, et al. A reevaluation of the risk factors for the recurrence of primary sclerosing cholangitis in liver allografts. Liver Transpl. 2009;15(3):330-40.

173. Gelley F, Zádori G, Görög D, Kóbori L, Fehérvári I, Gámán G, et al. Recurrence of primary sclerosing cholangitis after liver transplantation - The Hungarian experience. Interv Med Appl Sci. 2014;6(1):16-8.

174. Ou B, Zhao J, Guan S, Lu A. Survival of Colorectal Cancer in Patients With or Without Inflammatory Bowel Disease: A Meta-Analysis. Dig Dis Sci. 2016;61(3):881-9.

175. Kummen M, Holm K, Anmarkrud JA, Nygard S, Vesterhus M, Hoivik ML, et al. The gut microbial profile in patients with primary sclerosing cholangitis is distinct from patients with ulcerative colitis without biliary disease and healthy controls. Gut. 2017;66(4):611-9. 
176. Dejea CM, Wick EC, Hechenbleikner EM, White JR, Mark Welch JL, Rossetti BJ, et al. Microbiota organization is a distinct feature of proximal colorectal cancers. Proceedings of the National Academy of Sciences of the United States of America. 2014;111(51):18321-6. 177. Nakamoto N, Sasaki N, Aoki R, Miyamoto K, Suda W, Teratani T, et al. Gut pathobionts underlie intestinal barrier dysfunction and liver T helper 17 cell immune response in primary sclerosing cholangitis. Nature Microbiology. 2019.

178. Buchholz BM, Lykoudis PM, Ravikumar R, Pollok JM, Fusai GK. Role of colectomy in preventing recurrent primary sclerosing cholangitis in liver transplant recipients. World $\mathbf{J}$ Gastroenterol. 2018;24(28):3171-80.

179. Vera A, Gunson BK, Ussatoff V, Nightingale P, Candinas D, Radley S, et al. Colorectal cancer in patients with inflammatory bowel disease after liver transplantation for primary sclerosing cholangitis. Transplantation. 2003;75(12):1983-8.

180. Nordenvall C, Olen O, Nilsson PJ, von Seth E, Ekbom A, Bottai M, et al. Colectomy prior to diagnosis of primary sclerosing cholangitis is associated with improved prognosis in a nationwide cohort study of 2594 PSC-IBD patients. Aliment Pharmacol Ther. 2018;47(2):238-45.

181. Bergquist A, Ekbom A, Olsson R, Kornfeldt D, Loof L, Danielsson A, et al. Hepatic and extrahepatic malignancies in primary sclerosing cholangitis. J Hepatol. 2002;36(3):321-7. 182. Pastore RL, Wolff BG, Hodge D. Total abdominal colectomy and ileorectal anastomosis for inflammatory bowel disease. Dis Colon Rectum. 1997;40(12):1455-64.

183. Mann CV. Total colectomy and ileorectal anastomosis for ulcerative colitis. World $\mathbf{J}$ Surg. 1988;12(2):155-9.

184. Bengtsson J, Borjesson L, Lundstam U, Oresland T. Long-term function and manovolumetric characteristics after ileal pouch-anal anastomosis for ulcerative colitis. $\mathrm{Br} \mathbf{J}$ Surg. 2007;94(3):327-32. 


\section{Appendix}

Supplementary table 1: ICD codes for the studied populations in the thesis.

\begin{tabular}{|c|c|c|c|c|}
\hline ICD versions & $\begin{array}{c}\text { Ulcerative } \\
\text { colitis }\end{array}$ & $\begin{array}{l}\text { Crohn's } \\
\text { disease }\end{array}$ & $\begin{array}{c}\text { Indeterminate } \\
\text { colitis }\end{array}$ & $\begin{array}{c}\text { Primary } \\
\text { Sclerosing } \\
\text { cholangitis }\end{array}$ \\
\hline ICD-7 & $\begin{array}{l}572.20, \\
572.21, \\
578.03\end{array}$ & $\begin{array}{l}572.00, \\
572.09\end{array}$ & 572.30 & $\begin{array}{l}575.05 \\
585.29\end{array}$ \\
\hline ICD-8 & $\begin{array}{l}563.10, \\
569.02\end{array}$ & 563.00 & $\begin{array}{l}563.98, \\
563.99\end{array}$ & 575.05 \\
\hline ICD-9 & $556^{*}$ & $555^{*}$ & 558 & $576 \mathrm{~B}$ \\
\hline ICD-10 & K51* & K50* & K52.3 & $\begin{array}{l}\text { K830A, } \\
\text { K830 }\end{array}$ \\
\hline
\end{tabular}


Supplementary table 2: the Nordic Medico-Statistical Committee (NOMESCO) codes for operations included in the thesis.

\begin{tabular}{|l|c|c|}
\hline \multirow{2}{*}{ Type of resection } & \multicolumn{2}{|c|}{ NOMESCO codes } \\
\cline { 2 - 3 } & 1974 & Version 6, 1997 \\
\hline Subtotal colectomy & $\begin{array}{c}4650,4651,4652,4653, \\
4654 \text { or any three of } \\
\text { segmental resections }\end{array}$ & $\begin{array}{c}\text { JFH00, JFH01, JFH10, JFH11, } \\
\text { JFH20, JFH30, JFH33, JFH40, } \\
\text { JFH96 or any three of segmental } \\
\text { resections }\end{array}$ \\
\hline Right sided resections & 4641 & JFB20, JFB21, JFB30, JFB31 \\
\hline Transverse resections & 4643 & JFB40, JFB41 \\
\hline Left sided resections & 4640,4644 & $\begin{array}{c}\text { JFB43, JFB44, JFB46, JFB47, } \\
\text { JFB60, JFB61, JFB30, JFB31, } \\
\text { JFB33, JFB40, JFB50, JFB60, } \\
\text { JFB61 }\end{array}$ \\
\hline Other colonic resections & $4621,4630,4631,4649$, & JFB50, JFB51, JFB63, JFB64, \\
& 4670, & JFB96, JFB97 \\
\hline Ileo-rectal anastomosis & 4650 & JFH00, JFH01, JFC40 or JFC41 \\
\hline Ileal-pouch anal & & \\
anastomosis & 4654,4823 & JFH30, JFH33, JGB50 or JGB60 \\
\hline
\end{tabular}


Supplementary table 3: Öresland score

\section{Score*}

1

$2 \quad 3$

1. No. Of bowel movements

$\begin{array}{llll}\text { Daytime } & \leq 4 & 5 & \geq 6 \\ \text { At night } & 0 & >1 / \text { week } & \geq 2 \text { /night }\end{array}$

2. Urgency (inability to defer evacuation $>30 \mathrm{~min}$ )

$$
\text { No Yes }
$$

\section{Evacuation difficulties}

(>15 min spent in toilet on any occasion during the week)

$$
\text { No Yes }
$$

\section{Soiling or seepage}

$\begin{array}{lll}\text { Daytime } & \text { No } & >1 / \text { week } \\ \text { At night } & \text { No } & >1 / \text { week }\end{array}$

\section{Inability to release flatus safely}

No Yes

6. Perianal soreness No Occasional Permanent

7. Protective pad

$\begin{array}{lll}\text { Daytime } & \text { No } & >1 / \text { week } \\ \text { At night } & \text { No } & >1 / \text { week }\end{array}$

8. Dietary restrictions ( avoid certain items that interfere with pouch function)

$$
\text { No Yes }
$$

9. Medications ( continuous or occasional)

No $\quad$ Yes

10. Social handicap (not able to resume full-time occupation or participate in social life)

No Yes

*Score range 0-16: overall good scores 0 , overall bad score 16 


\section{Supplementary table 4: Short form-36 (SF-36)}

Instruktion: Detta formulär innehåller frågor om hur Du ser på Din hälsa. Informationen skall hjälpa till att följa hur Du mår och fungerar i Ditt dagliga liv. Besvara frågorna genom att sätta ett kryss i den ruta Du tycker stämmer bäst in på Dig. Om Du är osäker, kryssa ändå i den ruta som känns riktigast.

\begin{tabular}{|c|c|c|c|c|c|}
\hline \multirow[b]{2}{*}{$\begin{array}{l}\text { I allmänhet, skulle Du vilja säga } \\
\text { att Din hälsa är: }\end{array}$} & Utmärkt & $\begin{array}{l}\text { Mycket } \\
\text { god }\end{array}$ & God & $\begin{array}{l}\text { Någor- } \\
\text { lunda }\end{array}$ & Dålig \\
\hline & & & & & \\
\hline & $\begin{array}{l}\text { Mycket } \\
\text { bättre nu } \\
\text { än för ett } \\
\text { år sedan }\end{array}$ & $\begin{array}{c}\text { Något } \\
\text { bättre nu } \\
\text { än för ett } \\
\text { år sedan }\end{array}$ & $\begin{array}{l}\text { Ungefär } \\
\text { detsamma }\end{array}$ & $\begin{array}{l}\text { Något } \\
\text { sämre nu } \\
\text { än för ett } \\
\text { år sedan }\end{array}$ & $\begin{array}{l}\text { Mycket } \\
\text { sämre } n \\
\text { än för et } \\
\text { år sedar }\end{array}$ \\
\hline$\frac{\text { Jämfört med för ett år sedan, hur }}{\text { skulle Du vilja bedöma Ditt }}$ & & & & & \\
\hline
\end{tabular}
allmänna hälsotillstånd nu?

3 De följande frågorna handlar om aktiviteter som Du kan tänkas utföra under en vanlig dag.

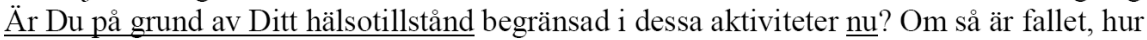
mycket?

$\begin{array}{ccc}\text { Ja, } & \text { Ja, } & \text { Nej, } \\ \text { mycket } & \text { lite } & \text { inte alls } \\ \text { begränsad } & \text { begränsad } & \text { begränsa }\end{array}$

(a) Ansträngande aktiviteter, som att springa, lyfta tunga saker, delta $\mathrm{i}$ ansträngande sporter

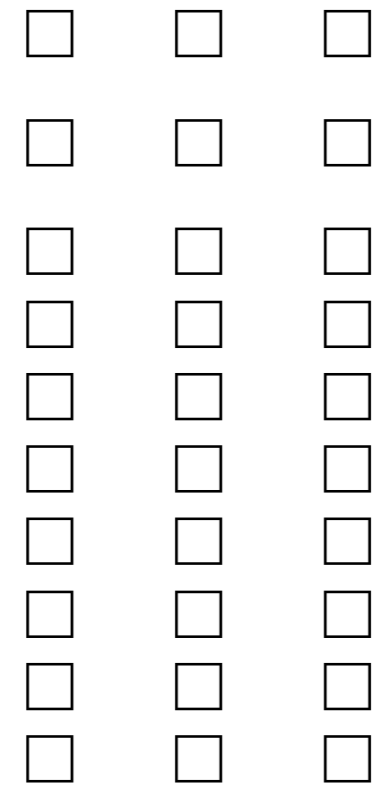


4 Under de senaste fyra veckorna, har Du haft något av följande problem i ditt arbete eller med andra regelbundna dagliga aktiviteter som en fölid av Ditt kroppsliga hälsotillstånd?

(a) Skurit ned den tid Du normalt ägnat åt arbete eller andra aktiviteter

(b) Uträttat mindre än Du skulle önskat

(c) Varit hindrad att utföra vissa arbetsuppgifter eller andra aktiviteter

(d) Haft svårigheter att utföra Ditt arbete eller andra aktiviteter (t ex genom att det krävde extra ansträngning)

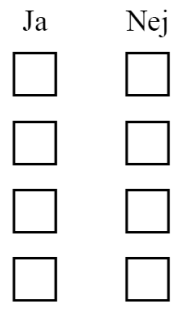

5 Under De senaste fyra veckorna, har Du haft något av följande problem i ditt arbete eller med andra regelbundna dagliga aktiviteter som en följd av känslomässiga problem (som $t$ ex nedstämdhet eller ängslan)?

(a) Skurit ned den tid Du normalt ägnat åt arbete eller andra aktiviteter

(b) Uträttat mindre än Du skulle önskat

(c) Inte utfört arbete eller andra aktiviteter så noggrant som vanligt

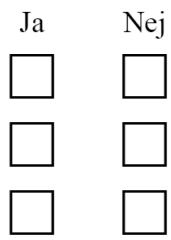

6 Under de senaste fyra veckorna, $\mathrm{i}$ vilken utsträckning har Ditt kroppsliga hälsotillstånd eller Dina känslomässiga

Inte alls

Lite Måttligt Mycket mycket problem stört Ditt vanliga umgänge med anhöriga, vänner, grannar eller andra?

7 Hur mycket värk eller smärta har Du haft under de senaste fyra veckorna?

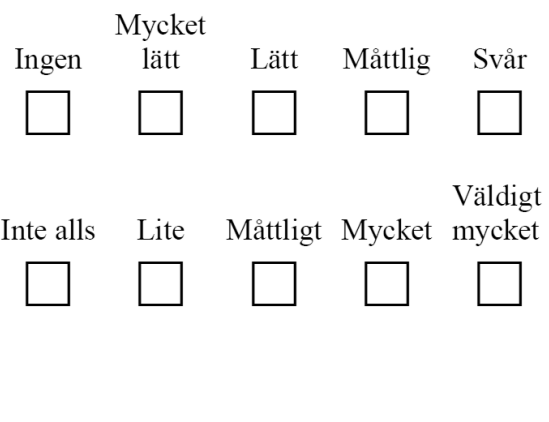

Mycket svår

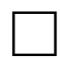

8 Under de senaste fyra veckorna, hur mycket har värken eller smärtan stört Ditt normala arbete (innefattar både arbete utanför hemmet och hushållssysslor)? 
9 Frågorna här handlar om hur Du känner Dig och hur Du haft det under de senaste fyra veckorna. Ange för varje fråga det svarsalternativ som bäst beskriver hur Du känt Dig.

Hur stor del av tiden under de senaste fyra veckorna...

(a) ...har Du känt Dig riktigt pigg och stark?

(b) ...har Du känt Dig mycket nervös?

(c) ...har Du känt Dig så nedstämd att ingenting kunnat muntra upp Dig?

(d) ...har Du känt Dig lugn och harmonisk?

(e) ...har Du varit full av energi?

(f) ...har Du känt Dig dyster och ledsen?

(g) ...har Du känt Dig utsliten?

(h) ...har Du känt Dig glad och lycklig?

(i) ...har Du känt Dig trött?

10 Under de senaste fyra veckorna, hur stor del av tiden har Ditt kroppsliga hälsotillstånd eller Dina känslomässiga problem stört dina möjligheter att umgås (t ex hälsa på släkt, vänner etc)?

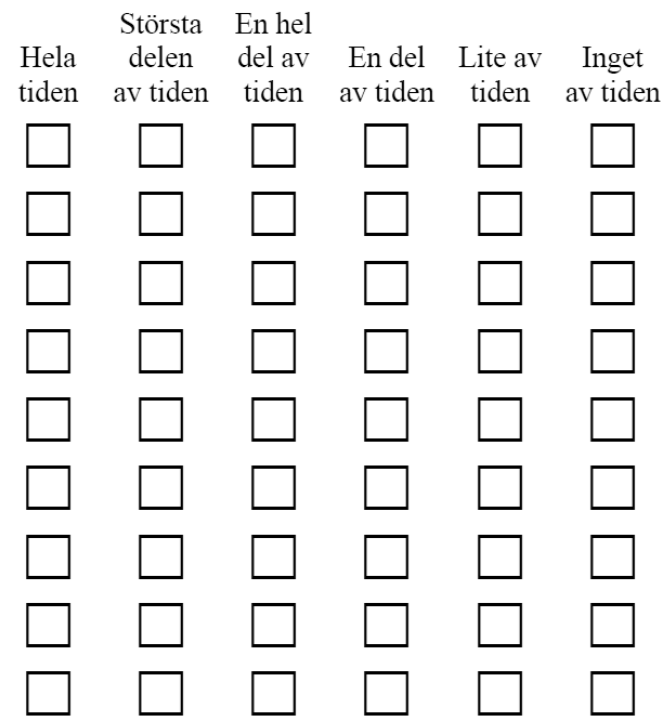

Största

Hela delen En del Lite av Inget tiden av tiden av tiden tiden av tiden

11 Välj det svarsalternativ som bäst beskriver hur mycket var och ett av följande påståenden STÄMMER eller INTE STÄMMER in på Dig. andra människor
(b) Jag är lika frisk som vem som helst av dem jag känner
(c) Jag tror min hälsa kommer att bli sämre
(d) Min hälsa är utmärkt

(a) Jag verkar ha lite lättare att bli sjuk än

$\begin{array}{cccc}\begin{array}{c}\text { Stämmer } \\ \text { precis }\end{array} & \begin{array}{c}\text { Stämmer } \\ \text { ganska } \\ \text { bra }\end{array} & \begin{array}{c}\text { Stämmer } \\ \text { inte sär- } \\ \text { skilt bra }\end{array} & \begin{array}{c}\text { Stämmer } \\ \text { inte alls }\end{array} \\ \square & \square & \square & \square\end{array}$


Supplementary table 5: Short health scale (SHS)

\section{Har Du symtom från Din tarmsjukdom?}

Inga symtom

L Lätta symtom

口 Måttliga symtom

G Ganska svåra symtom

- Svåra symtom

Mycket svåra symtom

2. Påverkar Din tarmsjukdom Din förmåga att klara av allt det Du måste eller vill $i$ livet?

Inte alls

口 I låg grad

口 I måttlig grad

I I ganska hög grad

I hög grad

I mycket hög grad

3. Skapar Din tarmsjukdom någon oro?
$\square$ Inte alls
口 I låg grad
I I måttlig grad
口 I ganska hög grad
I hög grad
I mycket hög grad

\section{Hur är Ditt allmänna välbefinnande?}

Mycket bra

口 Bra

G Ganska bra

口 Dåligt

- Mycket dåligt

Förfärligt 


\section{Supplementary table 6: Baron-Ginsberg score (BG score)}

0: Normal mucosa (no inflammation).

1: Granulated, oedematous, loss of normal mucosal vascularity (mild inflammation).

2: "1" + hyperemia and Contact bleeding (moderate inflammation).

3: "1+2" + ulceration, spontaneous mucosal bleeding (Severe inflammation). 


\section{Papers}

The papers associated with this thesis have been removed for copyright reasons. For more details about these see:

http://urn.kb.se/resolve?urn=urn:nbn:se:liu:diva-161507 


\title{
FACULTY OF MEDICINE AND HEALTH SCIENCES
}

\author{
Linköping University Medical Dissertation No. 1670, 2019 \\ Department of clinical and experimental medicine (IKE) \\ Linköping University \\ SE-581 83 Linköping, Sweden
}

www.liu.se 